\author{
SZEGEDI TUDOMÁNYEGYETEM \\ TERMÉSZETTUDOMÁNYI ÉS INFORMATIKAI KAR \\ BIOLÓGIA DOKTORI ISKOLA \\ ÉS \\ MTA SZEGEDI BIOLÓGIAI KUTATÓKÖZPONT
}

\title{
A mesenchymalis őssejtek funkcionális heterogenitása nem gyulladásos és gyulladásos mikrokörnyezetben
}

Ph.D. értekezés

Szabó Enikő

Témavezetök:

Monostori Éva, Ph.D., D.Sc.

Czibula Ágnes, Ph.D.

Szeged

2015 
I. Rövidítések jegyzéke

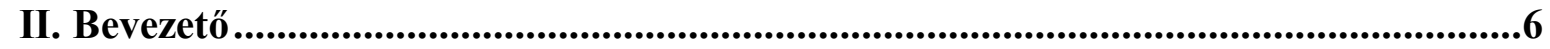

II.1. A mesenchymalis őssejtek (MSC) definiálása .................................................6

II.2. Az MSC-k funkciói és jelentősége .................................................................

II.3. Az MSC-k differenciálódása, szerepe a sérült szövetek újraképződésében..............9

II.4. Az MSC-k szerepe az érképződésben .......................................................... 10

II.5. Az MSC-k szerepe az immunválasz szabályozásában és a gyulladás csökkentésében

II.5.a. Az MSC-k immunmoduláló képességének fiziológiás eredete.........................13

II.5.b. Az MSC-k és a veleszületett immunitás ...................................................... 14

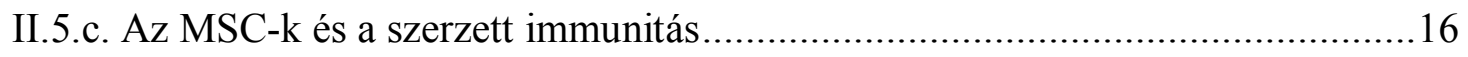

II.5.d. Az MSC-k immunszuppresszív faktorai................................................. 17

II.6. Az MSC-k funkcióit befolyásoló tényezők: mikrokörnyezet és heterogenitás ........20

II.6.a. A gyulladásos mikrokörnyezet hatása az MSC-k funkcióira ..........................20

II.6.a.1. Differenciáció és proangiogén hatás ................................................20

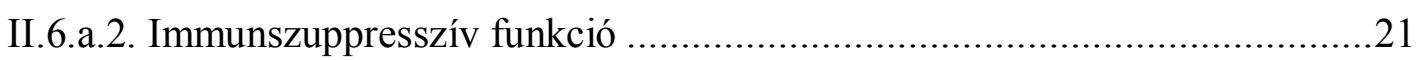

II.6.b. Az MSC funkciók inter- és intrapopulációs heterogenitása ...........................23

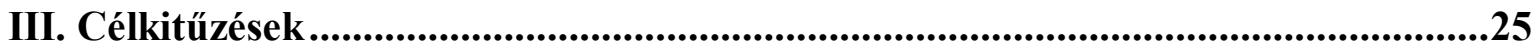

IV. Anyagok és módszerek...........................................................................................26

IV.1. Az MSC kultúra izolálása, fenntartása és klónozása.........................................26

IV.2. Sejtfelszíni markerek vizsgálata áramlási citometriával...................................26

IV.3. In vitro zsírsejt és csontképző sejt irányú differenciáció ...................................28

IV.4. Zsírsejt differenciáció vizsgálata AdipoRed ${ }^{\mathrm{TM}}$ reagenssel és citofluorimetriával ..28

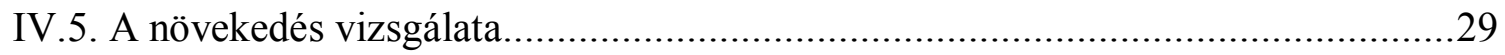

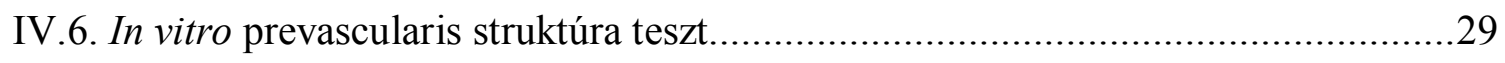

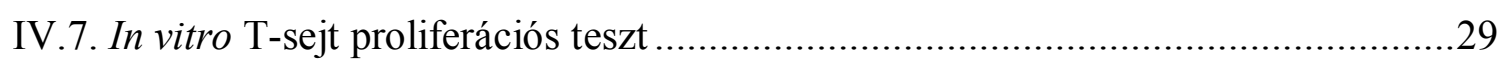

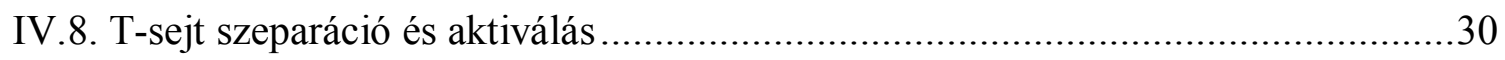

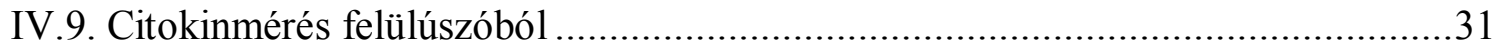

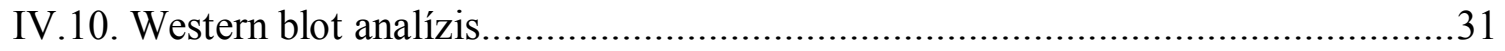

IV.11. Kvantitatív valós idejű (real-time) polimeráz láncreakció (qRT-PCR)................32

IV.12. Késői típusú túlérzékenységi reakció kiváltása..............................................33

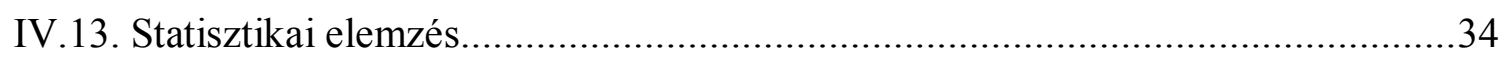




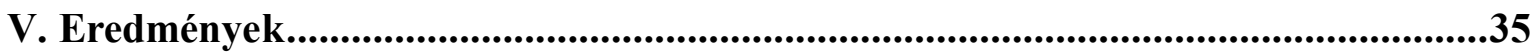

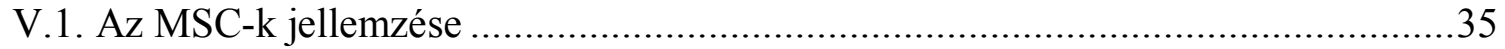

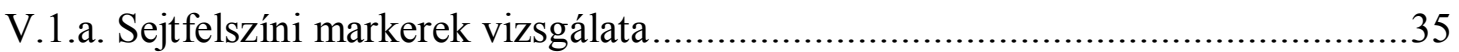

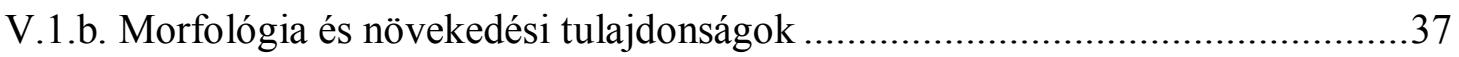

V.1.c. In vitro csontképző és zsírsejt irányú differenciálódás....................................38

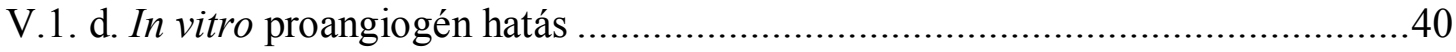

V. 2. Immunszuppresszív aktivitás és immunszuppresszív faktorok; T-sejt osztódás

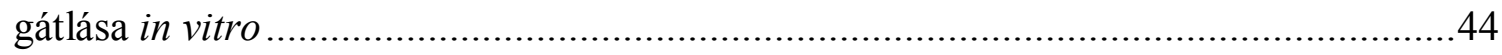

V.2.a. Az MSC-k in vitro T-sejt osztódást gátló hatása...........................................44

V.2.b. Az immunszuppresszív faktorok génkifejeződése az MSC klónokban ............47

V.2.c. Az in vitro T-sejt osztódás gátlásának hatásmechanizmusa ............................47

V.3. Gyulladásos faktorok hatása az MSC-k funkcióira .............................................49

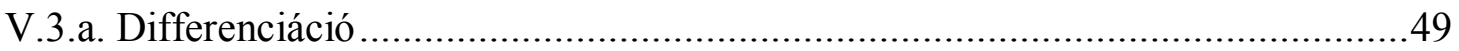

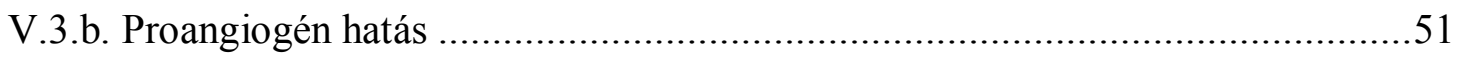

V.3.c. T-sejt proliferáció gátlás in vitro modellrendszerben....................................52

V.4. In vivo DTH egérmodell alkalmazása az MSC-k és MSC klónok

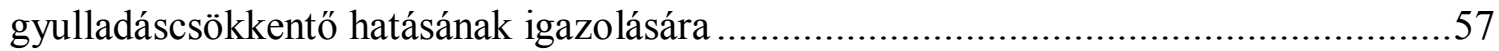

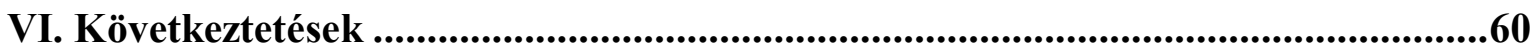

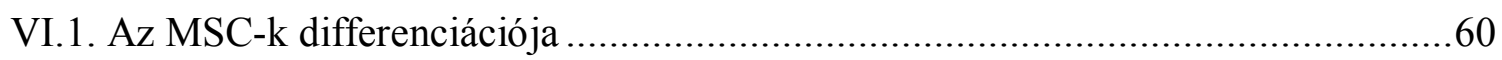

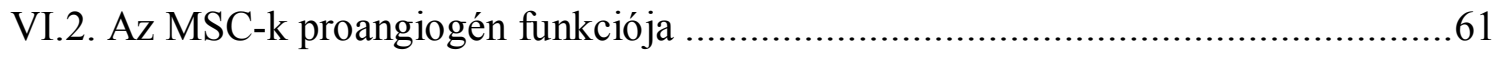

VI.3. Az MSC-k immunszuppresszív funkciója .....................................................62

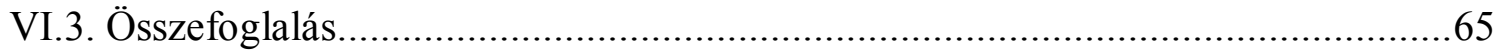

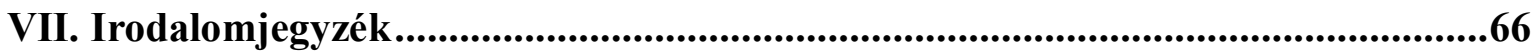

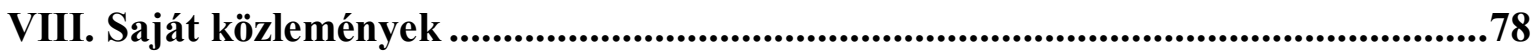

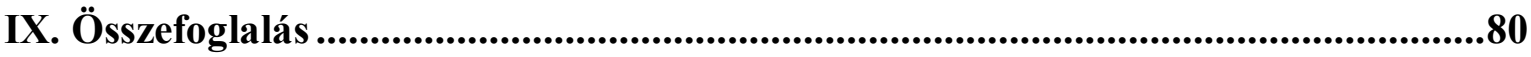

X. Summary ...................................................................................................................83

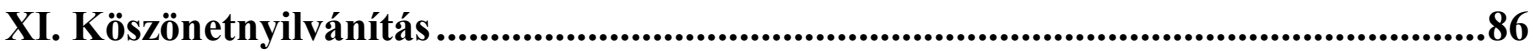




\section{Rövidítések jegyzéke}

1-MT: 1-metil-triptofán

4T1: egér emlőkarcinóma sejtvonal

Angpt 1: angiopoietin-1

Bglap: bone gla protein (csont Gla fehérje)

cAMP: ciklikus adenozin-3'-5'-monofoszfát

CD: cluster of differentiation (csoportdetermináns fehérjék)

cDNS: copy (másolati) DNS

CFSE: karboxifluoreszcein-diacetát-szukcimidilészter

ConA: concanavalin A

Ct: threshold cycle (áttörési ciklus)

CXCL: chemokine (C-X-C motif) ligand (kemokin (C-X-C motívumot tartalmazó) ligand)

DMEM: Dulbecco's modified Eagle's medium (Dulbecco által módosított Eagle-féle médium)

DMSO: dimetil-szulfoxid

DNS: dezoxiribonukleinsav

DTH: delayed type hypersensitivity (késői típusú túlérzékenységi reakció)

EDTA: etilén-diamin-tetraecetsav

FBS: fetal bovine serum (magzati borjúszérum)

Gal-1: galektin-1

GAPDH: glicerinaldehid-3-foszfát-dehidrogenáz

GFP: green fluorescent protein (zöld fluoreszcens fehérje)

GOI: vizsgálandó gén (gene of interest)

GVHD: graft versus host disease (graft-versus-host betegség)

H5V: egér szív kapilláris endotél sejtvonal

HGF: hepatocyte growth factor (májsejt növekedési faktor)

HLA-G: humán leukocita antigén-G

HSC: hematopoietic stem cell (hematopoietikus össejt)

HUVEC: human umbilical vein endothelial cell (humán köldökzsinór véna eredetű endotélsejt)

IDO: indolamin-2,3-dioxigenáz enzim

IFB: immunfluoreszcencia puffer

IFN- $\gamma$ : interferon-gamma 
IGF-1: insulin-like growth factor-1 (inzulinszerü növekedési faktor-1)

IL: interleukin

L-NMMA: NG-metil-L-arginin-acetát

MHC: major histocompatibility complex (fö hisztokompatibilitási komplex)

mRNS: messenger ribonukleinsav (hírvivő ribonukleinsav)

MSC: mesenchymal stem cell (mesenchymalis össejt)

NK-sejt: natural killer sejt (természetes ölősejt)

NO: nitrogén-monoxid

NOS: nitrogén-monoxid-szintáz enzim

PBS: phosphate buffered saline (foszfáttal pufferelt fiziológiás sóoldat)

PCR: polymerase chain reaction (polimeráz láncreakció)

PD-1: programmed cell death 1 (programozott sejthalál-1)

PD-L: programmed cell death ligand (programozott sejthalál ligand)

PDT: population doubling time (populáció kétszereződési idő)

PE: fikoeritrin

PGE2: prosztaglandin E2

PI: propídium-jodid

PLP: proteolipid protein

PTGS2: prosztaglandin-endoperoxid szintáz 2

qRT-PCR: quantitative real-time polymerase chain reaction (kvantitatív valós idejü polimeráz láncreakció)

Runx2: Runt related factor 2 (Runt-szerü transzkripciós faktor-2)

SD: standard deviance (standard deviáció)

Sca-1: stem cell antigen 1 (őssejt antigén-1)

SEM: standard error of the mean (az átlag standard hibája)

Spp1: secreted phosphoprotein 1 (szekretált foszfoprotein-1)

Stro-1: sztróma sejtantigén-1

Th: T helper cell (segítő T-sejt)

TNF- $\alpha$ : tumor necrosis factor alpha (tumor nekrózis faktor-alfa)

TGF- $\beta$ : transforming growth factor beta (transzformáló növekedési faktor-béta)

VCAM-1: vascular cell adhesion molecule 1 (vascularis sejtadhéziós molekula-1)

VEGF: vascular endothelial growth factor (ér-endotél növekedési faktor)

vWF: von Willebrand faktor 


\section{Bevezető}

\section{II.1. A mesenchymalis őssejtek (MSC) definiálása}

A felnőtt csontvelöben elkülöníthetünk egy alaktanilag fibroblasztokra emlékeztető sztrómális sejtpopulációt. Ezek a sejtek in vitro kultúrában a tenyésztőedény aljához tapadnak (1), in vivo mezodermális eredetü szöveteket, mint csont-, porc-, zsír- és vérképzést segítő sztróma hoznak létre (2), és önmegújításra képesek. Ennek kísérletes bizonyítékául szolgál, hogy egyetlen sejtből létrejövő kolónia is immunhiányos egerek bőre alá ültetve apró, csonttal körülvett csontvelő „szervecskét” képez, melyet a recipiens szervezetének hematopoietikus őssejtjei (HSC) benépesítenek (3). A fent említett jellemzők tükrében ezeket a sejteket mesenchymalis őssejteknek (4) vagy sztrómasejteknek nevezzük.

Kolóniaképző, multipotens sejtek nem csak a csontvelőben fordulnak elő, hanem minden szövetünkben és szervünkben, mint például az agy, lép, máj, vese, tüdő, csecsemőmirigy, hasnyálmirigy, izom-, zsír-, porc- és ínszövet, izületi belhártya, fogak gyökérhártyája, nagy erek, mint az aorta és végezetül perifériás vér, köldökzsinór vér és magzatvíz (5-13). Ezekben a tanulmányokban a szerzők nem egységes protokoll és kritériumrendszer alapján izolálták az MSC-szerü sejteket, mivel az MSC-knek saját, csak rájuk jellemző sejtfelszíni antigénjük nincsen. Az MSC-k felszínén meglévő markermolekulák fajonként $(14,15)$, állattörzsenként (16) és szövetenként $(13,17)$ is eltérő mintázatot mutatnak. A humán MSC meghatározására a Nemzeközi Sejtterápiás Társaság (ISCT: International Society for Cellular Therapy) a következő kritériumrendszert fogalmazta meg (18): az MSC

- kitapad a tenyésztőedény aljához (adherens)

- $\quad$ speciális sejtfelszíni antigénprofil jellemzi:

○ $\geq 95 \%$ pozitív CD90, CD105 és CD73 molekulákra

○ $\leq 2 \%$ pozitív CD45, CD34, CD14, CD11b, CD79a, CD19 és MHC

II vérsejtfejlődési sorokra jellemző molekulákra

- multipotens: in vitro differenciáltatható csontképző, porc- és zsírsejt irányba.

Az egér MSC definiálásánál alkalmazhatjuk az adherenciát és multipotenciát, azonban az ISCT sejtfelszíni markerekre vonatkozó javaslatainál figyelembe kell vennünk, hogy az 
egér MSC sejtfelszíni markerprofilja nem teljesen egyezik az emberével (1. táblázat). Például a CD90 kifejeződését egér MSC-n ellentmondások övezik (14,15).

\begin{tabular}{|l|l|c|c|}
\hline Sejtfe Iszíni antigé & \multicolumn{1}{|c|}{ Fe hé rje } & Ember & Egér \\
\hline CD13 & alanin-aminopeptidáz & ++ & $+/-$ \\
\hline CD29 & $\beta 1$-integrinlánc & ++ & ++ \\
\hline CD44 & hialuronsav receptor & ++ & ++ \\
\hline CD49e & $\alpha 5$-integrinlánc & ++ & ++ \\
\hline CD73 & ekto-5'-nukleotidáz & ++ & + \\
\hline CD90 & Thy-1 antigén & ++ & $+/-$ \\
\hline CD105 & endoglin & ++ & ++ \\
\hline CD106 & $\begin{array}{l}\text { VCAM-1: vascular cell adhesion molecule 1 (vascularis } \\
\text { sejtadhéziós molekula 1) }\end{array}$ & $++*$ & ++ \\
\hline CD146 & $\begin{array}{l}\text { MCAM: melanoma cell adhesion molecule (melanoma } \\
\text { sejtadhéziós molekula) }\end{array}$ & ++ & ++ \\
\hline CD166 & $\begin{array}{l}\text { ALCAM: activated leukocyte cell adhesion molecule } \\
\text { (aktivált leukocita sejtadhéziós molekula) }\end{array}$ & ++ & + \\
\hline CD271 & $\begin{array}{l}\text { LNGFR: low affinity nerve growth factor receptor (kis } \\
\text { affinitású idegnövekedési faktor receptor) }\end{array}$ & ++ & n.a. \\
\hline Sca-1 & stem cell antigen 1 (őssejt antigén-1) & ++ & - \\
\hline SSEA-4 & $\begin{array}{l}\text { stage-specific embrionic antigen-4 (stádium-specifikus } \\
\text { embrionális antigén-4) }\end{array}$ & ++ & ++ \\
\hline STRO-1 & stromal precursor antigen 1 (sztrómális elöalak antigén-1) & ++ & n.a. \\
\hline MSCA-1 & $\begin{array}{l}\text { mesenchymal stem cell antigen 1 (mesenchymalis össejt- } \\
\text { antigén-1) }\end{array}$ & ++ & n.a. \\
\hline
\end{tabular}

1. táblázat. Az ember és az egér MSC sejtfelszíni marker antigénjei. $A+/-$ jelek azt jelzik, hogy a populáció hány százaléka fejezi ki az adott antigént: $++(50-100 \%),+(<50 \%)$ és - (0\%). További jelölések: +/- (ellentmondó adatok); n.a. (nincs adat); * (TNF- $\alpha$ kezelés hatására fejezödik ki). A táblázat összeállitásához a következö közleményeket használtuk fel: $(15,19)$.

\section{II.2. Az MSC-k funkciói és jelentősége}

Az MSC-k amellett, hogy számos sejttípussá képesek differenciálódni, számos biológiailag aktív faktort is termelnek (20), és ezen képességeik alapján a sérülést, szövetpusztulást követő regenerációban vehetnek részt. A regeneráció során szükség van az elhalt szövetek pótlására és az újonnan képződőtt szövetben új erek kialakulására, illetve a sérülést követő gyulladásos folyamatok csillapítására (1.ábra). Az MSC-k egyrészt segíthetik a sérült szövetek regenerációját azáltal, hogy a regenerálandó szövet 
irányába differenciálódnak, vagy apoptózis- és hegképződésgátló anyagokat szabadítanak fel, valamint trofikus faktorokkal stimulálják a nyugvó szöveti progenitor sejtek osztódását (21). Másrészt a sérülés helyén támogatják az új erek képződését proangiogén faktorok termelésével (22), és pericitaként funkcionálva támaszthatják az újonnan képződő ereket (23). Harmadrészt a szövetpusztulás során fellépő gyulladást és immunválaszt gátolhatják (24). Az MSC-k különböző folyamatokban betöltött szerepét külön taglaljuk differenciálódási és faktortermelési szempontból.

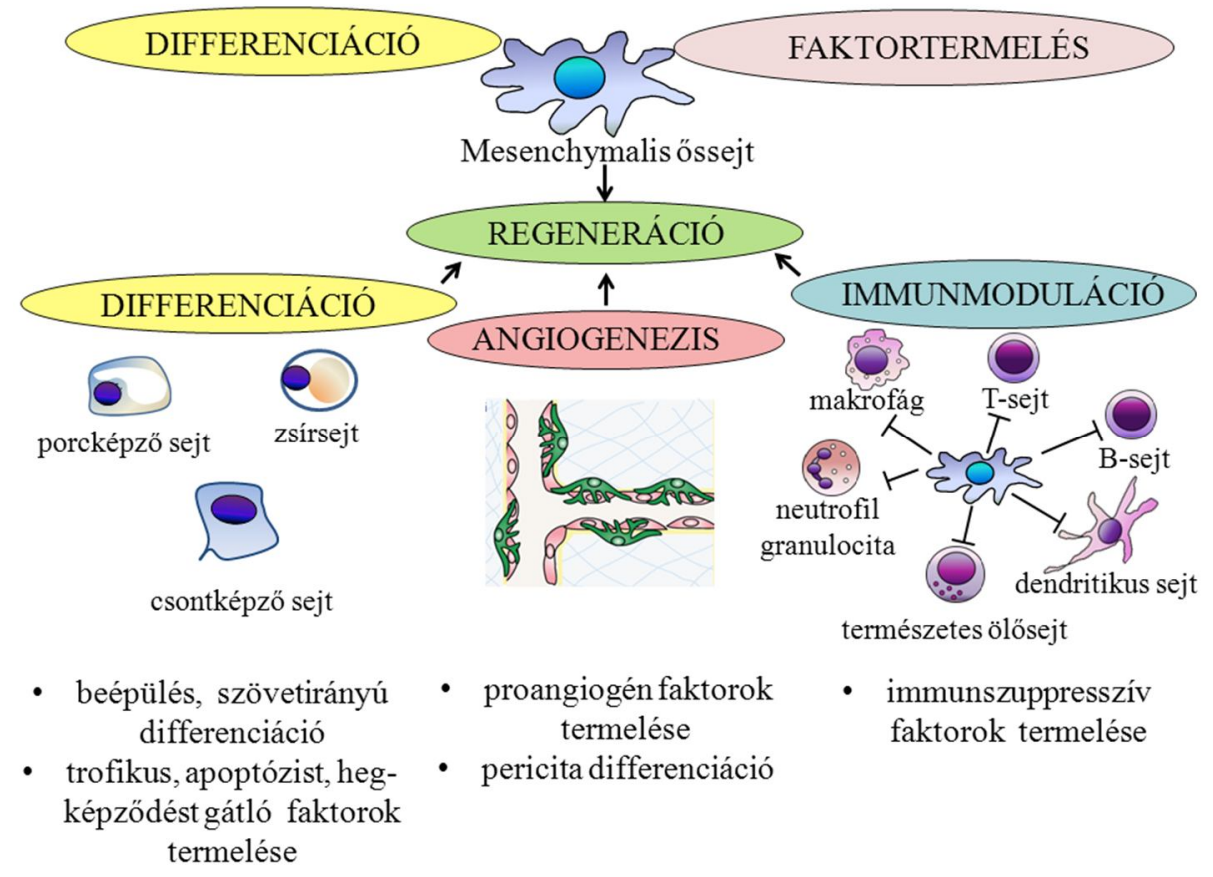

\section{1.ábra. Az MSC-k kettős tulajdonságának megnyilvánulása a szöveti regeneráció folyamatában.}

A fent említett funkcióikat kiaknázva az MSC-k a hematopoietikus őssejtekhez hasonlóan sejtterápiás eszközként alkalmazhatóak, felhasználási módjuk azonban rendkívül sokféle lehet a sejtek közvetlen vénába oltásától, az ásványhordozóra kitapasztott sejtek transzplantációján át az MSC-k által termelt faktorok, mikrovezikulák bejuttatásáig. A klinikumban való megjelenést a betegségmodellekben kapott biztató eredmények alapozták meg. Az MSC-k klinikai kipróbálása 1995-ben kezdődött (25) és napjainkban nagyon intenzíven zajlik. Az egyesült államokbeli Nemzeti Egészségügyi Intézet (National Institutes of Health, NIH) által létrehozott ClinicalTrials.gov honlap 
adatbázisába eddig több mint 650 olyan tesztet regisztráltak (2015. október), amelyben mesenchymalis őssejteket vagy sztrómasejteket használtak terápiás célból. A honlap adatai szerint már 39 országban folynak klinikai vizsgálatok MSC-kel, és a klinikai tesztek fele 2es klinikai fázisba lépett (26). Az MSC terápiával kezelni kívánt betegségek köre rendkívül szerteágazó, és vannak olyan területek, melyeknél több biztató eredmény is összegyült: reumás izületi gyulladás, artrózis $(27,28)$, szisztémás lupus erythematosus (29-31), miokardiális infarktus (32-36), Crohn-, és graft-versus-host betegség (GVHD) $(37,38)$. Mivel az MSC-k a szervezetben a meglévő tumorokba vándorolnak, ez a tulajdonságuk felvetette annak a lehetőségét, hogy a sejtölő faktorok termelésére genetikailag módosított MSC-k a daganatban hatékonyan pusztítsák a rákos sejteket. Citokinek, elődrogokat átalakító enzimek, érképződést gátló és apoptózist elősegítő anyagok termelésére módosított MSC-k hatékonynak bizonyultak különböző in vivo tumormodellekben. Ugyanakkor a genetikailag módosított MSC-k használata nem ismert kockázatot jelenthet, épp ezért daganatterápiára nem használnak módosított MSC-ket (39).

\section{II.3. Az MSC-k differenciálódása, szerepe a sérült szövetek újraképződésében}

Mint már említettük, az MSC-k a szövetek újraképződése során közvetlenül beépülhetnek az adott szövetbe különféle sejtekké történő differenciáció után. Az MSC-k in vitro differenciáltathatóak mezodermális (csont-, porc-, zsír-, ín- és izomszövet) irányokba $(40,41)$. A későbbiekben a felsorolt irányokba az MSC in vivo differenciációja is igazolást nyert, több kísérletes állatmodellben és humán regeneratív terápiában sikerült bizonyítani az MSC-k differenciáció utáni közvetlen beépülését a sérült szövetbe. A humán csontvelőből izolált, kitapadó MSC-k egér szívizomba oltva beépültek, szívizommá differenciálódtak, ezekre a sejtekre jellemző fehérjéket (dezmin, $\beta$-miozin nehéz lánc, $\alpha$ aktinin, troponin T) fejeztek ki, és a sejtekben szarkomer struktúrák is felfedezhetőek voltak (42). Kecske csontvelői, kitapadó, multipotens, zöld fluoreszcens fehérjével (GFP) jelölt MSC-k kecskék térdizületében sebészi úton kialakított artrózis modellben szignifikánsan serkentették a sérülés regenerációját, és GFP-jel alapján kimutathatóak voltak az újonnan képződő porcszövetben (43). Patkány csontvelői, fluoreszcensen jelölt, $\mathrm{CD} 31^{-}, \mathrm{CD} 34^{-}, \mathrm{CD} 45^{-}, \mathrm{CD} 29^{+}, \mathrm{CD} 90^{+}$MSC-k kísérletes patkány szívizomelhalás modellben szívizomba oltva szívizomsejtekké differenciálódtak, és az új erek képződésében is részt vettek dezmin, troponin T, illetve von Willebrand faktor (vWF) festődés alapján (44). Egér csonttörés modellben egér csontvelői CD11b ${ }^{-}, \mathrm{CD}^{2} 5^{-}, \mathrm{CD} 3^{+}$, 
CD44 ${ }^{+}, \mathrm{CD} 29^{+}$MSC-k az eltört csontvégeknél képződő új csontszövetben, a kalluszban csontképző sejtekké és csontsejtekké differenciálódtak (45).

Az MSC-k terápiás hatékonyságát több kísérletes modellben és klinikai tesztben igazolták, de a legtöbb esetben nem volt kimutatható az MSC-k beépülése a regenerálódó szövetbe, amiből az következik, hogy az MSC-k a szöveti differenciációt serkenthetik egy másik mechanizmus által is, mégpedig az apoptózist gátló és a nyugvó szöveti őssejtek osztódását stimuláló növekedési faktorok termelésével (46). A már említett patkány szívizomelhalás modellben az MSC-k in vitro szövettenyészetben proangiogén ér-endotél növekedési faktort (vascular endothelial growth factor, VEGF), apoptózist gátló adrenomedullint, mitogén és proangiogén májsejt (hepatocita) növekedési faktort (HGF) és mitogén inzulinszerü növekedési faktor-1-et (IGF-1) termeltek, melyek szintje az MSC-vel kezelt állatok vérében megnőtt, ellenben azt nem bizonyították, hogy ezeket a faktorokat valóban az MSC-k termelték in vivo (44). A már szintén korábban említett csonttörés modellben a kallusz endostealis részén csontképző sejtekké differenciálódott MSC a törött csont összeforrásában alapvető szereppel bíró csont morfogenetikus fehérje-2-t (bone morphogenetic protein 2, BMP-2) szekretált, amely irányítja a csontképző sejtek differenciációját a sérülés helyén $(45,47)$. Természetesen léteznek olyan vizsgálatok is, ahol az MSC-k differenciációja a regenerációban kizárható volt a kísérleti elrendezés miatt. Példának okáért, ha az MSC-k kondicionált médiumát használjuk fel terápiás eszközként, akkor az MSC-k által termelt parakrin faktorok vagy mikrovezikulák vizsgálatára nyílik lehetőség. Az MSC szekrétum számos citokin, növekedési faktor, extracelluláris mátrixfehérje és szövetmegújulásban részt vevő enzim egyvelege (48), míg az 50-1000 nm-es mikrovezikulák fehérjék mellett mRNS, mikroRNS és lipidmolekulákat is tartalmaznak (49). Az MSC-k kondicionált médiuma és az abból kinyert mikrovezikulák gyógyászatilag hatékonynak bizonyultak több kísérletes állatmodellben is mint például szívinfarktus, máj-, vese-, tüdő-, és agykárosodás (50-55).

\section{II.4. Az MSC-k szerepe az érképződésben}

Vannak olyan esetek, amikor a szöveti regenerációhoz fokozottan szükség van új erek képződésére is pl. szélütést vagy infarktust követően, illetve krónikus sebek, szervkárosodások, vagy csonttörések gyógyulásánál, esetleg szövettranszplantáció után. Több kísérleti adat is alátámasztja, hogy az MSC-k serkentik az érképződést, mely 
folyamatban mind az eret alkotó sejtek irányába történő differenciáció, mind a proangiogén faktorok termelése szereppel bír (56).

Az MSC-k endotélsejt irányba történő differenciációját ellentmondások övezik, ugyanis az MSC-k az in vitro differenciáció során kifejezik az endotélsejtekre jellemző molekulákat (CD31, CD34, VEGF receptor 1 és 2, vascularis sejtadhéziós molekula-1 (VCAM-1), vWF) (57,58), ez azonban még nem elegendő, hogy ezeket a differenciálódott MSC-ket endotélsejteknek nevezhessük. Az endotélsejt differenciációt funkcionális tesztekkel is igazolni kell. Az egyik lehetőség erre az érszerü ún. prevascularis struktúra teszt, melyben az MSC-k VEGF jelenlétében speciális mátrixon prevascularis struktúrákat képeznek $(57,58)$. Ez a speciális mátrix a Matrigél, amely az Engelbreth-Holm-Swarm egér szarkóma sejtek által termelt, alapmembránhoz hasonló összetételü extracelluláris mátrix. VEGF hatására nem minden esetben fejeződtek ki az említett endotélsejt markerek (59). Ezen túlmenően csak egyetlen tanulmány van, melyben elektronmikroszkópos felvételekkel támasztották alá, hogy a differenciáltatott MSC-k endotélsejtekre jellemző morfológiával, Weibel-Palade testekkel, szoros kapcsolatokkal és caveolakkal rendelkeznek (60). Emellett kevés adatot találhatunk a szakirodalomban, mely az MSC-k in vivo endotélsejt differenciációját megerősíti. Az egyik ilyen adat az előző fejezetben már említett kísérletes patkány szívizomelhalás modellből származik, amikor szívizomba adva az MSC-ket, azok szívizomsejteken kívül endotélsejtekké is differenciálódtak vWF festődésük alapján (44). Az MSC-k endotélsejt irányú differenciációjával szemben az elmúlt években sokkal inkább teret hódított az a nézet, hogy az MSC-k a csontvelőben, más szervekben és szövetekben is erek közelében helyezkednek el és gyakorlatilag pericitaként funkcionálnak (21). Ennek az elméletnek az alapját az a munka képezte, melyben humán vázizomból, méhlepényből, hasnyálmirigyből és zsírszövetből pericitákat izoláltak, melyek pozitívak voltak MSC markerekre (CD44, CD90, CD73 és CD105), negatívak endotélsejt, hematopoietikus sejt és vázizom markerekre (CD34, CD45, CD56), és differenciáltathatóak voltak zsír, csont, porc és izom irányba (61). Az erek közelében elhelyezkedő MSC-ket CD146 kifejeződésük alapján lehetett megkülönböztetni a többi MSC-től. A CD146 ${ }^{+}$MSC-k a csontvelői MSC-knek az az alpopulációja, mely képes volt megújítani önmagát és létrehozni azt a niche-t, melyből származott vagyis hidroxiapatit kristállyal együtt bőr alá beültetve parányi csontvelőszervet alakított ki, melyben HSC-k jelentek meg (3). Egy friss közlemény szerint a $\mathrm{CD}_{146^{-}}$csontvelői multipotens sztrómasejtek in vitro angiogenezis modellben kevésbé hatékonyak, mint az erek 
közelében elhelyezkedő CD146 ${ }^{+}, \mathrm{CD} 34^{-}$MSC-k (62). A fenti adatok arra utalnak, hogy a különböző szövetekben lévő periciták is MSC-k, de nem minden MSC helyezkedik el erek közelében, és az eltérő lokalizáció funkcionálisan eltérő jellegeket von maga után. MSC-k forrásául nem csak periciták, de a nagy artériák külső rétege is szolgálhat (63). Másrészt pedig az in vitro angiogenezis modellben az MSC mint támasztósejt, pericita vesz részt (23). Ebben az in vitro modellben a humán MSC-k és a humán köldökzsinór véna eredetű endotélsejtek (human umbilical cord vein endothelial cell, HUVEC) az együttenyésztés során Matrigél vagy más extracelluláris mátrix komponens nélkül is epidermális növekedési faktor jelenlétében prevascularis struktúrákat képeztek. A HUVEC-ek által in vivo alkotott ereket az MSC pericitaként körülvette és élettartamukat meghosszabította (64).

Az érképződés serkentésének másik aspektusa az, hogy az MSC-k proangiogén és mitogén faktorokat termelnek. Az MSC-k VEGF-et, HGF-et, IGF-1-et, transzformáló növekedési faktor- $\beta$-t (TGF- $\beta$ ), fibroblaszt növekedési faktor-2-t (FGF-2), angiopoietin-1et, monocita kemoattraktáns protein-1-et, interleukin(IL)-6-ot, placenta-eredetű növekedési faktort és még számos más proangiogén funkciójú faktort szekretálnak (22,50,65-67). Ezeknek a faktoroknak a hatása az endotélsejtek angiogenzisének egyes lépéseire (endotélsejtek osztódása, vándorlása, extracelluláris mátrix bontása, prevascularis struktúra képzése) in vitro rendszerekben jól tetten érhető. A proangiogén faktorok termelése által az MSC-k, vagy az MSC sejtkultúra kondicionált médiuma fokozta az endotélsejtek osztódását és vándorlását egy speciális tenyésztőedény felső kamrájából az alsó kamrájába szérum mentes környezetben, illetve csökkentette az endotélsejtek apoptózisát $(50,68,69)$. Sőt, az MSC-k kondicionált médiuma serkentette az endotélsejtek extracelluláris mátrix bontását is (69). Ezen túlmenően önmagában az MSC-k kondicionált médiuma is kiváltotta az endotélsejtek prevascularis struktúrákba rendeződését Matrigélen vagy fibringélen $(65,70)$. Saját kísérleteink alapján tudjuk, hogy az MSC-k által termelt galektin-1 (Gal-1) fontos szereppel bír az MSC-k érképződést elősegítő szerepében mind in vitro, mind in vivo, ugyanis galektin-1 hiányos egérből származó MSC-k endotélsejtekkel kevesebb prevascularis struktúrát képeztek, és a 4T1 emlőtumor mikroerzettségét is a vad típusú MSC-khez képest kevésbé növelték (71). 


\section{II.5. Az MSC-k szerepe az immunválasz szabályozásában és a gyulladás csökkentésében}

II.5.a. Az MSC-k immunmoduláló képességének fiziológiás eredete

Az ezredforduló felfedezései közé tartozik, hogy az MSC-k gátolják az immunválaszt (72), mely a kutatók figyelmét az MSC-k immunrendszerrel való kapcsolatára irányította. A csontvelői MSC-k immunmoduláló képességét abból eredeztetik, hogy az MSC-k elsődleges szerepe a csontvelöben a hematopoietikus niche fenntartása és védelme a gyulladásos folyamatoktól. Kísérleti adatok arra utalnak, hogy a hematopoietikus niche kialakítása nem minden csontvelői MSC alpopuláció sajátsága, csak a CD146 ${ }^{+}$, vagy nestin ${ }^{+}$MSC-kre jellemző. Ezt bizonyítja, hogy a CD146 ${ }^{+}$MSC-k bőr alá oltva kis csontvelő szervet, hematopoietikus niche-t alakítanak ki, melybe hematopoietikus sejtek telepednek meg (3). Más megfigyelések szerint az intermedier filamentum nestint kifejező MSC-k számos, a hematopoiezis fenntartásához szükséges faktort termelnek, például az angiopoietin-1-et, osteopontint, IL-7-et, VCAM-1-et és kemokin (C-X-C) motívumot tartalmazó ligand-12-t (CXCL-12). A nestin ${ }^{+}$MSC-k vérképzés támogatásában betöltött szerepét in vivo is igazoták, mivel a nestint kifejező sejtek szelektív elpusztítását a HSC-k számának csökkenése követte, illetve a letálisan besugárzott egereknél a HSC-k a csontvelő benépesítésekor a nestin ${ }^{+}$MSC-k közelében telepedtek meg (73). Egyéb szövetekben előforduló MSC-k immunmoduláló képességének eredetére két elképzelés áll fenn. Az egyik szerint a szöveti sérülés esetén kisebb erek is károsodhatnak, miáltal a periciták nyugalmi állapota megbomlik, aktiválódnak és trofikus, illetve immunmoduláló sejtekké válnak, amelyek azonosak a szöveti MSC-kkel (20). A másik elmélet szerint az immunszabályozásban a különböző szövetek sztrómájának van szerepe, ugyanis nem csak a szöveti MSC-k, de más sztrómális sejtek, mint pl. különböző szövetekből származó fibroblasztok is immunszuppresszívek (74). Példának okáért az artrózisban vagy reumás izületi gyulladásban szenvedő betegek izületi belhártyájából izolált fibroblasztok is gátolták a T-sejtek proliferációját és citokintermelését (75). Ezzel szemben a megváltozott müködésű izületi belhártya fibroblasztjai aktív módon közremüködnek a reumás izületi gyulladás fenntartásában és feltehetőleg kialakulásában is (76). 


\section{II.5.b. Az MSC-k és a veleszületett immunitás}

Az MSC-k a veleszületett immunitásban résztvevő sejttípusok müködését befolyásolják, így az immunválasz során a kórokozók elleni első védelmi vonalat is szabályozzák.

A makrofágoknak kétféle altípusa alakulhat ki a kórokozók molekuláris mintázata és különböző immunsejtek által kibocsátott mediátorok hatására. Az M1-es gyulladásos makrofágok nagy mennyiségü gyulladásos citokint (tumor nekrózis faktor-alfa (TNF- $\alpha$ ), IL-1 $\beta$, IL-12), különböző kemokineket és sejtpusztító hatású reaktív oxigén- és nitrogéngyököket (pl. NO) termelnek, ezáltal képesek a kórokozókat elpusztítani és a gyulladást, illetve a Th1-függő immunválaszt fokozni. Az M2-es makrofágok ezzel szemben gyulladásgátló hatásúak, immunszuppresszívek, és szerepük van a szövetek regenerációjában (77). Az MSC-k képesek a makrofágok polarizációját M2-es irányba eltolni, amit a gyulladásgátló hatású IL-10 emelkedett szintű termelése és a gyulladásos citokin csökkentett felszabadítása jellemez (78). Az MSC-k immunszupresszív hatását több in vivo szövetregenerációs állatmodellben is összefüggésbe hozták a makrofágok M2 irányba történő polarizációjával. Például az MSC-k segítették a kísérletesen előidézett infarktuson átesett patkányok szívizmának regenerációját, melyben a szívizomba adott MSC-k maguk köré toborozták az M2-es makrofágokat (79). Az MSC-k makrofágokkal in vitro együtt-tenyésztve polarizálták a makrofágokat M2-es altípus irányába, mely emelkedett M2-es, csökkent M1-es altípusra jellemző citokintermelésben és enzimaktivitásban tükröződött. Feltehetőleg a szívizomba juttatott MSC-k is hasonló módon befolyásolják a magukhoz toborzott M2-es makrofágok citokin- és enzimaktivitását, erre vonatkozóan azonban az in vivo modellben a szerzők közvetlen bizonyítékkal nem szolgáltak (79).

A neutrofil granulociták is a természetes immunitás fontos elemei. A neutrofil granulociták által bekebelezett baktériumok elpusztításának egyik elfogadott mechanizmusa a szabadgyöktermelés, ugyanakkor a szabadgyöktermelés nem megfelelő szabályozása kóros állapotokat, súlyos szövetkárosodást is előidézhet a szervezetben (80). Az MSC-vel elöinkubált neutrofil granulociták kevesebb szabadgyököt termelnek, de a kísérletes (opszonizált zimozán) fagocitáló képességük nem változik (81). Mi több, egy tanulmány arról számolt be, hogy az MSC-k segítik a neutrofilok baktérium bekebelezését (82). Emellett az MSC-k csökkentik a neutrofil granulociták apoptózisát kokultúra rendszerben (81). 
A természetes ölősejtek (natural killer, NK) szerepe a fertőzött és daganatsejtek elpusztítása és gyulladásos citokinek termelése. Az MSC-k gátolják az NK-sejtek osztódását, aktivációs receptor kifejeződését és sejtölő aktivitását különböző tumorsejtvonalakkal szemben $(83,84)$, ellenben az MSC-k hatása az NK-sejtek gyulladásos citokintermelésére nem egyértelmű (85).

A dendritikus sejtek legfontosabb feladata a feldolgozott antigének bemutatása a Tsejteknek, mely folyamat hidat képez a veleszületett és a szerzett immunitás között. Az MSC-k gátolják a dendritikus sejtek in vivo érését, citokintermelését és nyirokcsomókba történő vándorlását (86). Májkárosodás in vivo modelljében az MSC kezelés előidézi a dendritikus sejtelőalakok reguláló típussá történő differenciációját, mely sejtek segíthetik a reguláló T-sejtek differenciációját (87).

\section{makrofágok:}

$\uparrow$ differenciáció gyulladáscsökkentö (M2) irányba, IL-10 termelés

$\downarrow$ differenciáció gyulladásserkentő (M1) irányba, NO termelés

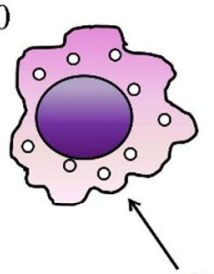

T-sejtek:

$\downarrow$ CD4+ és CD8+ T-sejtek osztódása

$\downarrow$ Th1 irányba differenciáció és Th1-es citokintermelés (IFN- $\gamma$ )

$\uparrow$ Th2 irányba differenciáció és citokintermelés (IL-4)

$\uparrow$ reguláló T-sejt differenciáció

$\downarrow$ Th17 irányba differenciáció és citokintermelés (IL-17)

neutrofil granulociták:

$\downarrow$ apoptózis

$\downarrow$ szabadgyök termelés

$\uparrow$ fagocitózis

\section{természetes ölósejtek:}

$\downarrow$ osztódás

$\downarrow$ aktivációs receptor kifejeződés

$\downarrow$ sejtölő folyamatok

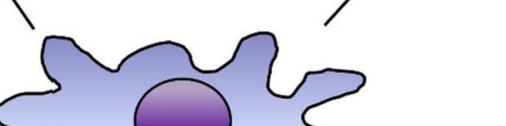
(1) 


\section{II.5.c. Az MSC-k és a szerzett immunitás}

A szerzett immunitás részeként a B- és T-sejtek klónjai receptoraikkal a patogének specifikus molekuláit (antigénjeit) ismerik fel lehetővé téve az adott kórokozó elleni hatékony védelmet (2. ábra). A T-sejtek miután receptorukkal felismerték az antigént, osztódásba kezdenek és különböző effektor funkciókat látnak el (citokintermelés, sejtölés). A B-sejtek az antigéneket felismerő ellenanyagok termelésére specializálódtak. A következőkben bemutatjuk, hogy az MSC-k hogyan befolyásolják ezeknek a sejteknek a müködését.

Az MSC-k szövettenyészetben gátolják a B-sejtek osztódását megrekesztvén a sejtciklusukat G0/G1 fázisban, és csökkentik a B-sejtek immunglobulin termelését is (88). Az MSC-k gátló hatása különböző kórképekre jellemző antitestek termelésére is tetten érhető. A szisztémás lupus erythematosus in vivo egér modelljében a ciklofoszfamiddal kombinált humán MSC adása jelentősen mérsékli a betegségre jellemző kettős-szálú DNS molekulák elleni antitestek mennyiségét az állatok szérumában (89). A sclerosis multiplex egér modelljében az autoantigénként használt proteolipid protein (PLP) fehérjével reagáló autoantitestek mennyiségét az MSC kezelés csökkenti (90).

Az MSC-k a humorális válasz effektor sejtjein kívül gátolják a gyulladásos T-sejtek (Th1, Th17) funkcióit is (91). Ilyen vonatkozásban az első megfigyelések egyike az volt, hogy az allogén vagy az autológ humán MSC-k egyaránt gátolják a PHA-stimulált $\mathrm{CD} 4^{+}$ és a CD8 ${ }^{+}$T-sejtek osztódását (92). Az MSC-k a CD4 ${ }^{+}$T-sejtek citokinszekrécióját Th2 irányba tolják el, ugyanis a humán MSC-k csökkentik a Th1 irányba differenciáltatott Tsejtek IFN- $\gamma$ termelését, és fokozzák a Th2 irányba differenciáltatott T-sejtek IL-4 szekrécióját. Megfigyelték azt is, hogy az MSC-k és az IL-2-vel kezelt perifériális vér mononukleáris sejtjeinek (peripheral blood mononuclear cells, PBMC) kokultúrájában magasabb a $\mathrm{CD}^{+}{ }^{+} \mathrm{CD} 25^{+}$reguláló T-sejtek száma az MSC nélküli PBMC kultúrához képest (93). Az MSC-k in vitro kokultúrában T-sejtekkel csökkentik a Th17-sejt differenciációnak kedvező citokinek mennyiségét, a Th17-sejtek arányát és IL-17 termelését (94). Az MSC-k különböző in vivo állatkísérletes betegségmodellekben is gátolják a T-sejtek által kifejtett patológiás, gyulladásos folyamatokat. Egerekben streptozotocinnal kiváltott 1-es típusú cukorbetegségben az inzulintermelő $\beta$-sejtek elleni T-sejtes immunválaszt a csontvelői MSC-k visszaszorították, így segítették a hasnyálmirigy regenerációját (95). 


\section{II.5.d. Az MSC-k immunszuppresszív faktorai}

Az MSC-k immunszuppresszív hatásának mechanizmusát sok tanulmány igyekezett feltárni, melyek rámutattak, hogy az MSC-k immunregulációja egy összetett, többfaktoros, fajspecifikus folyamat. A következő fejezet a humán és egér MSC-k legfontosabb immunszuppresszív faktorairól fog áttekintést adni (3. ábra). Mivel a vizsgálatok többsége az MSC-k T-sejtekre gyakorolt hatására irányult, így ebben a fejezetben az ebben a folyamatban részt vevő faktorokról lesz szó a felfedezés időrendi sorrendjében.

A humán MSC-k számos, az immunválasz szabályozásában szereppel bíró mediátort termelnek. A TGF- $\beta 1$ az immuntolerancia kialakításában vesz részt a T- és Blimfociták proliferációjának, differenciációjának és túlélésének szabályozásával (96). A HGF-et kezdetben mint májsejtekre és különböző epitélsejtekre mitogén hatású fehérjét tartották számon. Immunreguláló szerepére először az a GVHD modellel végzett tanulmány világított rá, melyben igazolták, hogy azon egerek bélepitéliuma, melyek vázizmába HGF-et transzfektáltak, kevésbé kársosodott, és párhuzamosan a T-sejtek májba történő infiltrációja csökkent (97). A humán MSC-k által termelt TGF- $\beta 1$ és HGF szerepe ellentmondásos, ugyanis ezeket a fehérjéket neutralizáló ellenanyagok enyhítették az MSC-k gátló hatását a kevert limfocita reakcióra (92), míg más csoportok által végzett vizsgálatokban a neutralizáló ellenanyagok nem befolyásolták az MSC-k osztódásgátló hatását aktivált T-sejtekre $(98,99)$. A nem klasszikus MHC I molekulák közé tartozó humán leukocita antigén-G (HLA-G) immunszuppresszióban betöltött szerepe a magzattal szembeni anyai tolerancia kialakításánál vált nyilvánvalóvá. Egyik szolubilis izoformája, a HLA-G5 kevert limfocita reakcióhoz adva részlegesen gátolja a T-sejtek osztódását (100). A HLA-G5 funkcióját az MSC-k T-sejt osztódásgátlásában több tanulmány is egyértelmüen bizonyította neutralizáló ellenanyagok segítségével (101-103). A prosztaglandin E2 (PGE2) szerepe azért merült fel, mert a T-sejtekben az EP2/EP4 receptorokon keresztül, cAMP-mediált úton a különböző jelátviteli folyamatok végül a Tsejtek osztódásának gátlását eredményezik (104). Az eddigi adatok ellentmondásosak: egyes tanulmányok arról számolnak be, hogy az MSC-kben a PGE2 szintézisének gátlása részlegesen vagy teljesen visszafordítja az MSC-k T-sejt osztódást gátló hatását (93,99,105,106), míg mások szerint a PGE2 szintézis gátlása nem befolyásolja az MSC-k ilyen funkcióját $(74,105,107)$. Nemcsak a humán MSC-k, hanem számos sejtféleség termel IL-10-et, egy olyan citokint, melynek meghatározó szerepet tulajdonítanak a gyulladásos 
és autoimmun kórképek kialakulásának megelözésében (108). Az MSC-eredetü IL-10 mégsem járul hozzá az MSC-k T-sejtekre kifejtett osztódásgátló hatásához (105). A humán MSC-k legfontosabb immunmoduláló faktora az indolamin-2,3-dioxigenáz (IDO), egy triptofán lebomlást katalizáló enzim, ami melléktermékként kinurenint és más anyagcseretermékeket eredményez. IDO-t többféle sejt is termel, pl. makrofágok, dendritikus sejtek és fibroblasztok $(74,109)$. Az IDO triptofánszegény környezetet teremtve vagy a kinurenin út anyagcseretermékeinek proapoptotikus hatásán keresztül gátolja a T-sejtek osztódását (109). A humán MSC-k által termelt IDO szerepét azok triptofán analóggal történő kezelésével több tanulmány is igazolja, mivel az IDO enzimmüködésének gátlása az MSC-k T-sejt osztódásának gátlását megszünteti $(74,99,106,107,110-112)$. A triptofán pótlása MSC-T-sejt kokultúrában megszünteti az MSC gátló hatását a T-sejtek osztódására, mely azt támasztja alá, hogy az IDO a triptofán megvonásán keresztül hat (110), míg más kísérletben a kinurenin is szignifikánsan csökkenti a T-sejtek osztódását (106).

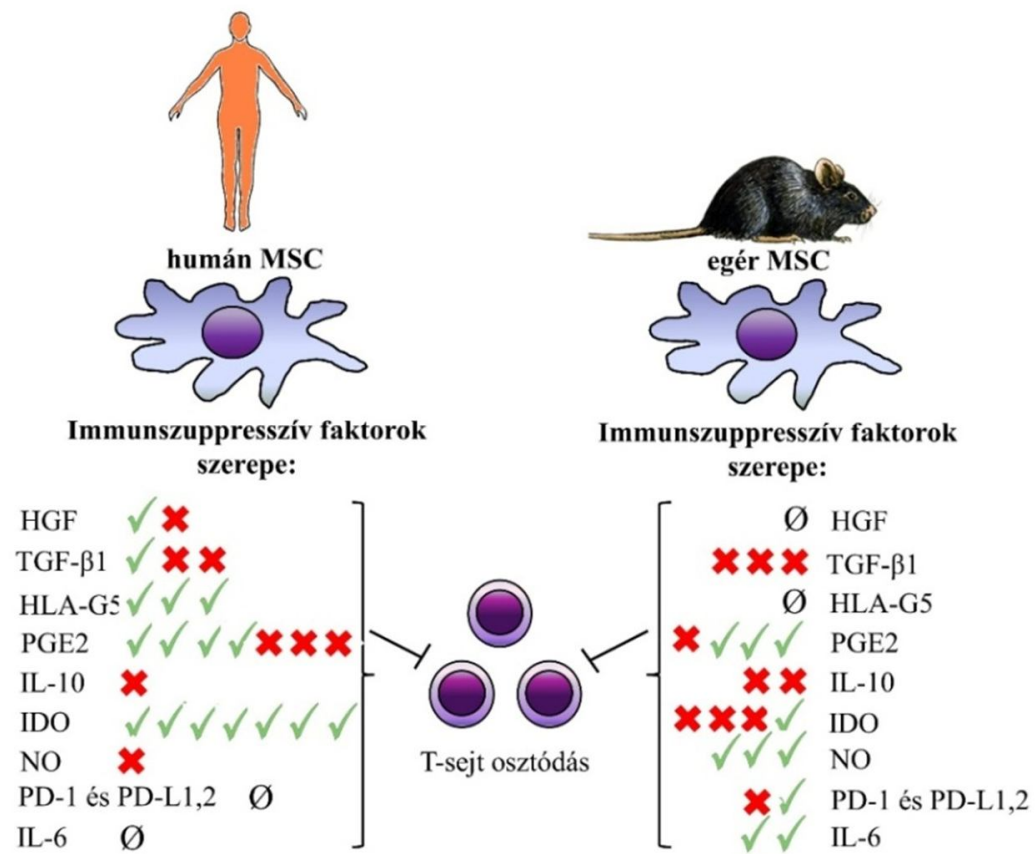

3. ábra. A humán és az egér MSC-k immunmoduláló faktorai. A zöld pipajelek és piros $X$-ek az adott immunszuppresszív faktor szerepét megerösitö vagy cáfoló közlemények számát jelzik. A Ø azt jelzi, hogy nem találtunk erre a faktorra vonatkozó adatot T-sejt osztódás gátlást illetően.

A rágcsáló MSC-k immunszuppresszív faktorai részben egyezőek a humán MSCével, ugyanakkor lényeges különbségeket is találhatunk. Az egér MSC-k konstitutívan 
kifejezik a TGF- $\beta 1$-et, és a TGF- $\beta 1$ gátolja a T-sejt osztódást (91), ugyanakkor a TGF- $\beta 1$ semlegesítése specifikus ellenanyaggal nem okoz változást az MSC immunszuppressziójában, ami a TGF- $\beta 1$ szerepét cáfolja (113-115). Két másik faktor, a HGF és IL-10 nem gátolja az egér T-sejtek osztódását (91), amit megerősítenek az MSCT-sejt kokultúrában IL-10-et semlegesítő ellenanyaggal kapott eredmények (113,115). Az egér MSC-k is konstitutívan szintetizálják a PGE2-t (91), de annak fontossága az immunszuppresszióban még vitatott. Specifikus gátlószerekkel több független csoport is igazolta a PGE2 részleges szerepét az MSC-k által T-sejtekre kifejtett osztódásgátlásban (91,114,116), míg mások kísérleteiben a PGE2 szintézis gátlása nem állította helyre a Tsejtek osztódását (115). A T-limfociták B7 kostimulációs molekulákkal homológiát mutató receptor membránfehérjéje, a programmed cell death 1 (programozott sejthalál-1, PD-1) és az antigént prezentáló sejtek felszínén lévő ligandmolekulái (PD-L-ek) között kialakuló kölcsönhatásaként a T-sejt receptoron és kostimulációs molekulákon keresztüli T-sejt aktiváció gátlást szenved (117). A limfocitákkal együtt tartott MSC-k felszínén a PD-1 ligandmolekuláinak (PD-L1 és PD-L2) kifejeződése indukálódik. A limfociták PD-1 molekulája és az MSC-k sejtfelszínén lévő PD-L1 és PD-L2 kölcsönhatásaként mind a Tsejtek, mind a B-sejtek osztódása csökken, ugyanis az ezeket a molekulákat semlegesítő ellenanyagok részben megszüntetik az MSC gátló hatását a T-sejtekre és B-sejtekre (118). A PD-1 siRNS-sel történő csendesítése szignifikánsan csökkenti az MSC-k in vitro immunszuppresszióját (119), míg English és kollégái szerint a PD-1 és ligandjainak blokkolása nem állítja helyre az MSC-k által gátolt T-sejt osztódást (91). Az IL-6-hoz mind gyulladás-serkentő, mind gyulladásgátló funkciók kapcsolhatók (120). Az egér MSCk által termelt IL-6 immunszuppresszív szerepét két közlemény hangsúlyozza. Az IL-6-ot semlegesítő ellenanyag részben feloldja az MSC-k gátló hatását (116), és az IL-6-deficiens MSC a vad típusú MSC-hez képest kevésbé gátolja a T-sejtek proliferációját (121). Az IDO részleges szerepét egér MSC T-sejtekre gyakorolt osztódásgátló hatásában eddig csak egyetlen közleményben mutatták ki (91), más kutatóknak ezt nem sikerült megismételni (99,114,115). A rágcsáló MSC-k fó immunszuppresszív faktora a nitrogén-monoxid (NO). A NO magas koncentrációban különböző hatásmechanizmusok révén gátolja a mitokondriális légzést, a fehérjeszintézist és DNS-, sejt-, illetve szövetkárosodást okoz (122). A NO-ot a különböző NO szintázok (endothelialis; neuronális és indukálható NOS) állítják elő (114). Rágcsálókban a makrofágok az L-arginin L-citrullinná átalakítása során nagy mennyiségü NO-t termelnek (123). MSC-kben az indukálható NOS (iNOS vagy 
NOS2) gyulladásos citokin stimulusra termeli a NO-t, mely gátolja a T-sejtek osztódását $(114,115)$. Az MSC-k által termelt NO in vivo funkcióját igazolja, hogy egér GVHD és izületi gyulladás modellben az iNOS-hiányos egérből származó MSC-k csekélyebb terápiás hatékonyságúak, mint a vad típusú egérből izolált MSC-k (115,121). Rendkívül izgalmas, hogy az emberből, kecskéből és nyúlból származó makrofágok nem rendelkeznek iNOS aktivitással (124). A humán-, sertés- és majomeredetű MSC-kben sem figyelhető meg iNOS aktivitás, és specifikus gátlószerrel nem igazolható a NO szerepe a T-sejt osztódás gátlásában, míg rágcsáló MSC-kben magasabb az iNOS aktivitás és az iNOS gátlásával az MSC-k osztódásgátló képessége jelentősen csökken (112,125).

Összegzésként megállapíthatjuk, hogy mind a humán, mind a rágcsáló MSC immunszuppressziójában a PGE2 részleges szereppel bír, az IDO a humán, a NO pedig a rágcsáló MSC-k meghatározó immunmoduláló faktora. A humán MSC immunszuppressziójában a HLA-G szerepét is több tanulmány megerősíti. A többi faktor esetében az eredmények meglehetősen ellentmondásosak, vagy a szerepüket illetően mindeddig csak kevés vizsgálat történt (3. ábra).

\section{II.6. Az MSC-k funkcióit befolyásoló tényezők: mikrokörnyezet és heterogenitás}

\section{II.6.a. A gyulladásos mikrokörnyezet hatása az MSC-k funkcióira}

Egyre gyülik azoknak az irodalmi adatoknak a sokasága, melyek azt támasztják alá, hogy az MSC-ket körülvevő mikrokörnyezet, legfóképpen a gyulladásos sejtközeg erőteljesen befolyásolja az MSC-k biológiai funkcióját. A gyulladásos környezet eltérően hat az MSC-k differenciációjára, proangiogén funkciójára és immunmodulációjára. A gyulladásos szövet, illetve az aktivált T-sejtek felülúszója gazdag gyulladáskeltő citokinekben (IFN- $\gamma$ és TNF- $\alpha$ ) (126). Az immunsejtek által kibocsátott gyulladáskeltő citokinek $(115,127)$ hatását az MSC-k funkcióira a következő két alfejezetben tárgyaljuk.

\section{II.6.a.1. Differenciáció és proangiogén hatás}

A gyulladásoskeltő citokinek hatását az MSC differenciációjára ellentmondások övezik. Az eddigi tanulmányokban leginkább a TNF- $\alpha$ szerepét vizsgálták a csont differenciációban. Míg egyes szerzők szerint a TNF- $\alpha$ gátolja a csont differenciációt (129132), mások szerint fokozza azt (133). Ha az MSC-t TNF- $\alpha$ és IL-17 kombinációjával kezeljük, a csont differenciáció szintén erősebb lesz (134). A harmadik álláspont szerint a 
TNF- $\alpha$ hatása koncentrációfüggő: alacsony koncentrációban $(0,01 \mathrm{ng} / \mathrm{mL})$ serkenti, magas koncentrációban (100 ng/mL) azonban gátolja a csont irányú differenciációt (135). A TNF$\alpha$ gátolja a zsír és porc irányú differenciációt is, mint ahogy egy másik gyulladásos citokin, az IL-1 $\beta$ is $(130,136)$. Az IFN- $\gamma$ hatásáról az MSC differenciációra eddig csak egy tanulmány számolt be, mely szerint IFN- $\gamma$ magas koncentrációban $(200 \mathrm{ng} / \mathrm{mL})$ gátolja az MSC-k in vitro csont differenciációját, míg alacsonyabb koncentrációban $(50 \mathrm{ng} / \mathrm{mL})$ nem (131). A gyulladásos környezet differenciációt gátló hatására egy másik bizonyíték az, hogy vad típusú egérbe oltva feltehetőleg az immunrendszer müködésének köszönhetően az MSC nem differenciálódik csont irányba, míg tímuszhiányos (nude) egérben igen. Továbbá a tímuszhiányos (nude) egérben az MSC in vivo csont differenciációját a T-sejtek oltása gátolta és vad típusú egérben az IFN- $\gamma$-t és TNF- $\alpha$-t semlegesítő ellenanyagok fokozták az MSC-k in vivo csont differenciációját (131).

Eddig csak egy közleményben találhatunk információt arról, hogy a gyulladásos környezet hogyan befolyásolja az MSC-k proangiogén funkcióját. Az IFN- $\gamma / \mathrm{TNF}-\alpha-$ előkezelt MSC-kben megnő a VEGF és hipoxia indukálta faktor-1 $\alpha$ szekréciója, mely hozzájárulhat ahhoz, hogy a citokinekkel elöstimulált MSC-k jobban elösegítik a tumor növekedését és az érképződését (137).

\section{II.6.a.2. Immunszuppresszív funkció}

Az MSC-k immunmoduláló funkciója a. „licensing” révén aktiválódik. Mivel erre a kifejezésre megfelelő magyar szakszó nem található a hazai szakirodalomban, a dolgozatban bevezettük a citokinavatás fogalmát. A citokinavatás folyamata során az MSC-k gyulladásos citokinekkel találkoznak, mint az IFN- $\gamma$, TNF- $\alpha$ és IL- $1 \alpha / \beta$, melyek az MSC-ket immunmoduláció tekintetében aktiválják, vagyis gyulladáscsökkentő fenotípus irányába tolják el. Ez utóbbi függ a felhasznált faktor típusától, koncentrációjától és a kezelés időtartamától (128). Egy másik tényező az, hogy a gyulladásos citokinek által közvetített immunszuppresszív tulajdonságot serkentő jelek mellett az MSC-k milyen arányban kapnak a gátló fenotípust elfojtó, immunstimuláló jeleket, mint például a Tolllike receptor (TLR) aktiváció. A TLR3 és TLR4 aktiváció csökkentette az MSC-k Jagged1 fehérje expresszióját, ezáltal gátolva a Notch1-függő T-sejt proliferáció gátlást (138). Emellett a TLR3 és TLR4 aktiváció indukálta az IL-1 $\beta$, IL-6, IL-8, a TNF-szerü apoptózis indukáló ligand (TRAIL) gyulladásos citokinek és kemokin (C-C motívum) ligand 5 (CCL5) expresszióját (139). Következésképp a TLR3/4 aktiváció az MSC-ket 
gyulladásserkentő irányba tolja el. Harmadrészt az MSC-k citokinavatása in vivo a lokálisan jelen lévő, egyéni, a patológiás folyamatok során változó citokinkoncetrációknak köszönhetően nehezen szabályozható. Következésképp a különböző betegségmodellekben az MSC-k eltérő időpontokban történő oltása különböző mértékben volt hatásos (140-142). Tehát in vivo környezetben a citokinavatás megfelelő végbemeneteléhez azt is figyelembe kell vennünk, hogy a betegség mely fázisában történik az MSC oltás. Az IFN- $\gamma$ és a TNF- $\alpha$ serkentő hatását az MSC-k immunszuppressziós képességére számos kísérlet igazolja (106,107,111). Ha az MSC-T-sejt kokultúrákban az MSC-k közel 100\%-ban gátolják a Tsejtek osztódását, akkor az MSC-k citokinavatásának nincs további gátlásnövelő hatása (91). Polchert és kollégái az in vitro eredményeket in vivo kísérletben is igazolni tudták: a GVHD egér modelljében az IFN- $\gamma$-val előaktivált MSC-k oltása hatásosabbnak bizonyult a betegség kialakulásának megelőzésében, mint a kezeletlen MSC-kkel való oltás (143). Az IFN- $\gamma$ döntő szerepét az MSC-k immunszuppresszív aktivitásának a fokozásában többféleképpen is igazolták. Az MSC-k szuppresszív hatását az aktivált T-sejtek osztódására az IFN- $\gamma$ receptor specifikus blokkoló antitest megszünteti (144). Az IFN- $\gamma-$ hiányos egér T-sejtjeinek proliferációját az MSC-k kevésbé gátolják, mint a vad típusú Tsejteket, ellenben a kokultúrához 1,25 ng/mL koncetrációban adott IFN- $\gamma$ jelentősen növeli az MSC-k gátló hatását IFN- $\gamma$ hiányos T-sejtekre (119). Az IFN- $\gamma$ receptor hiányos egérből izolált MSC-k sem gátolják az aktivált T-sejtek osztódását, és a vad típusú MSC-vel ellentétben nem segítik elő a GVHD-s egerek túlélését (115). Ren és munkatársai azt is kimutatták, hogy az MSC-k immunszupresszív aktivitásának fokozására az IFN- $\gamma$ és TNF$\alpha$ vagy IL-1 $\alpha / \beta$ kombinációja hatásosabb, mint az egyes citokinek önmagukban (115). A citokinavatás MSC immunszuppressziót serkentő hatása azon alapulhat, hogy az MSC-k IFN- $\gamma$-val és TNF- $\alpha$-val történő kezelése immunszuppresszív faktorok mint az IL-6, IL-10, HGF, PD-L1, TGF- $\beta 1$, PGE2, NO és IDO1, és immunsejteket toborzó kemokinek mint CXCL-9 és CXCL-10 fokozott termelését váltja ki $(91,115,145)$. Ezek a mediátorok MSC kultúrában, aktivált T-sejtekkel vagy gyulladásos citokinekkel történő találkozás hiányában nem, vagy csak nagyon alacsony szinten szekretálódnak. Az egér MSC-ben stimulálatlanul, normál tenyésztési körülmények között az IDO, PD-L1 és PD-L2 kifejeződés hiányzik, a HGF kifejeződés pedig alacsony. Citokinkezelés nélkül a humán és egér MSC iNOS és IDO sem mRNS, sem pedig fehérje szinten nem fejeződik ki $(99,110,115,125)$. 
Ezekből az adatokból látszik, hogy míg a gyulladásos környezet egyértelműen fokozza az MSC-k immunszuppresszív aktivitását, addig kevés adat áll rendelkezésünkre azzal kapcsolatban, hogy a gyulladásos környezet hogyan befolyásolja az MSC-k proangiogén funkcióját, másrészt a gyulladásos citokinek a tanulmányok többségében gátolják az MSC-k differenciációját. Ez utóbbi megállapítások alátámasztása azonban még további vizsgálatokat igényel.

\section{II.6.b. Az MSC funkciók inter- és intrapopulációs heterogenitása}

Az MSC kultúrák heterogenitása kétféleképpen értelmezhető: egyrészt az egyedek között megfigyelt, azaz MSC populációk közti (interpopulációs), másrészt az MSC populáción belüli (intrapopulációs), tehát az egy egyedből izolált MSC kultúra heterogenitását jelenti. A heterogenitás vagy sokféleség tükröződhet a sejtek morfológiájában, kolóniaképzésében, osztódási rátájában, sejtfelszíni markerprofiljában, differenciációs potenciáljában és különböző biológiailag aktív faktorok termelésében (146). A populációk közti heterogenitás egyik példája, hogy 17 donor csontvelöjéből származó MSC-k növekedési üteme, alkalikus foszfatáz aktivitása, illetve csont irányba differenciáltatva a csontspecifikus gének kifejeződése eltérő volt (147). Egy másik példa, hogy 5 különböző egértörzsből izolált csontvelői MSC-k eltérő Sca-1, CD34 és CD106 kifejeződést mutattak és különböző mértékben differenciálódtak csont, porc és zsír irányba (16).

A populáción belüli heterogenitást klonális heterogenitásnak is nevezzük. A klonális heterogenitás vizsgálata visszanyúlik egészen az MSC kutatás gyökereihez, Alexander J. Fridenstein és kollégáinak munkásságához, akik megfigyelték, hogy a csontvelői sztrómális sejtek egy sejtből kialakuló kolóniáinak egy része diffúziós kamrában in vivo csont- és porcszövetet formált, míg más kolóniák megőrizték fibroblasztszerü morfológiájukat (1). Ezt követően Pittenger és munkatársai bizonyították elsőként, hogy a humán csontvelői MSC klónok között vannak olyanok, melyek csont, porc és zsír irányba is differenciáltathatóak. Ezeket tekintették a közlemény szerzői valódi MSC-nek. A korlátozottabb differenciációs képességgel rendelkező klónokról feltételezték, hogy a fenntartás folyamán elveszítették differenciációs képességüket, vagy valamilyen differenciációs útvonal irányába elkötelezett progenitorsejtekről van szó (148). A klonális heterogenitás vizsgálatát Muraglia és kollégái 185 humán csontvelői MSC klónra terjesztették ki. A klónok egynegyede mindhárom irányba képes volt differenciálódni, a 
legtöbbjük pedig csont és porc irányba differenciálódott csak. Olyan klónt nem találtak, amely csont-zsír, porc-zsír, kizárólag porc vagy kizárólag zsír irányba differenciálódott volna (149). Mivel a fenntartás során a klónok elveszítették először a zsír, majd a porc irányú differenciálódási képességüket, feltételezték, hogy a tapasztalt kiindulási heterogenitás hátterében egy csont irányba történő fokozatos elköteleződés áll. Egy későbbi tanulmány ellentmond ennek a hipotézisnek, ugyanis itt a vizsgált 96 humán csontvelői MSC klón között a csont, porc és zsír irányú differenciáció mind a 8 lehetséges kombinációja előfordult. A két donorból izolált klónok közel fele tripotens volt, és a nem differenciálódó klónok aránya elenyésző volt (150). Ezzel szemben az Okamoto és kollégái által vizsgált telomerázzal immortalizált humán klónok többsége elveszítette differenciálódási képességét, és a tripotens klónok száma is csekély volt (151). Más szövetböl, mint például a zsírszövetböl izolált MSC populáció is különböző potenciálú klónokat tartalmaz, legfőképpen csont-porc és porc-zsír irányba differenciálódókat (152). A fenti adatok rávilágítanak az MSC populációk differenciálódási heterogenitására, mely lehet az intenzív sejttenyésztés, a speciális in vitro differenciáltatási protokollok következménye, vagy tükrözheti az MSC populációk természetes módon előforduló különböző irányokba elkötelezett sejtek sokféleségét is.

$\mathrm{Az}$ immunszuppresszív funkciót érintő heterogenitást illetően nem rajzolódott ki egységes kép az MSC biológiában, mivel az ilyen irányú vizsgálatok száma csekély és eredményeik ellentmondásosak. Míg egy meglehetősen kevés, specifikusan az egyes klónokra vonatkozó adatot tartalmazó tanulmány szerint az MSC klónok immunmodulációja egyöntetü (113), más csoportok szembeötlő különbségekre hívják fel a figyelmet $(115,153,154)$. 


\section{Célkitüzések}

A mesenchymalis őssejtek sejtterápiás felhasználási köre rendkívül széles, melyek közül az immunológiai kórképek kezelése, illetve a regeneratív medicinában való alkalmazásuk a legígéretesebb területek. Az MSC-k segítik a kóros immunológiai folyamatok révén sérült szövetek regenerációját, illetve a terápia során érvényesül gyulladáscsökkentő és immunválaszt befolyásoló hatásuk. Az ilyen célból történő felhasználás során az MSC-k gyulladásos környezetbe kerülnek, mely befolyásolhatja az MSC-k terápiás hatékonyságát. A gyulladásos környezetben jelen lévő gyulladáskeltő citokinek mint az IFN- $\gamma$ és TNF- $\alpha$ serkentik számos MSC immunszuppresszív faktor termelését, ezáltal fokozva az MSC-k immunszuppresszív hatékonyságát, ugyanakkor csökkentik differenciálódási potenciáljukat. Az MSC-k felhasználásának sikerességét még egy másik tényező is befolyásolhatja a gyulladásos mikrokörnyezeten felül, ez pedig az MSC-k heterogenitása. Régóta ismert, hogy az MSC-k morfológiailag, növekedési és differenciálódási képességüket tekintve egymáshoz viszonyítva heterogén populációk. Ugyanakkor kevés adat áll rendelkezésünkre abban a vonatkozásban, hogy az MSC egy adott populációjának egyedi sejtjei különböznek-e immunreguláló képességük szempontjából, illetve egy sejt szinten a gyulladásos mikrokörnyezet hogyan befolyásolja a differenciálódási és immunszabályozó funkciókat. Ennek megértéséhez a következő kérdéseket fogalmaztuk meg:

1) Milyen paraméterekkel jellemezhetőek az egy sejtből kiinduló MSC kultúrák eltérései, vagyis az MSC populáció heterogenitása?

2) Annak összehasonlítása, hogy a monoklonális MSC sejtkultúrák milyen faktorokon keresztül és milyen mértékben fejtik ki T-sejt proliferációt gátló hatásukat.

3) Hogyan befolyásolja a gyulladásos környezet az egyedi MSC klónok immunszuppresszív aktivitását és differenciálódási képességét? 


\section{Anyagok és módszerek}

\section{IV.1. Az MSC kultúra izolálása, fenntartása és klónozása}

Az általunk használt MSC-ket Dr. Uher Ferenc (Országos Vérellátó Szolgálat, Össejtbiológiai Laboratórium) izolálta egy vad típusú C57BL/6 egér combcsontjából és sípcsontjából Peister és munkatársai által leírt módszerrel (16).

Az MSC-k fenntartása komplett médiumban (KM) történt, mely DMEM (Gibco ${ }^{\circledR}$ ) médium kiegészítve 10\% hőinaktivált magzati borjú szérummal (FBS, Gibco ${ }^{\circledR}$ ), 2 mM Lglutaminnal $\left(\mathrm{Gibco}^{\circledR}\right)$ és 100-100 $\mu \mathrm{g} / \mathrm{mL}$ penicillin-sztreptomicinnel (PAA). Az MSC-ket $37^{\circ} \mathrm{C}-\mathrm{os}, 5 \% \mathrm{CO}_{2}$ koncentrációjú párásított inkubátorban növesztettük.

A monoklonális kultúrák alapításához az egy C57BL/6 egérből származó MSC alapkultúrából a 10. passzázst követően $0,05 \%$ tripszin-EDTA (Gibco ${ }^{\circledR}$ ) tartalmú médiummal eltávolítottuk az MSC-ket a tenyésztőedény aljáról, és médiummal hígítottuk annyira, hogy 96-lyukú szövettenyésztő lemezre (Orange Scientific) szétosztva minden egyes lyukba statisztikailag 1 sejt kerüljön. CKX41 inverz fénymikroszkópot (Olympus Holding Europa $\mathrm{GmbH}$ ) használtunk a valóban 1 sejt eredetű klónok kiválogatására. A monoklonális kultúrákat 10\% FBS-t és 5\% lószérumot $\left(\right.$ Gibco $\left.^{\circledR}\right)$ tartalmazó DMEM/F-12 médiumban $\left(\mathrm{Gibco}^{\circledR}\right)$ növesztettük fel, és az összes MSC morfológiát megtartó klón közül random módon ötöt (MSC2-MSC6) választottunk ki további vizsgálatra.

\section{IV.2. Sejtfelszíni markerek vizsgálata áramlási citometriával}

Az MSC kritériumoknak megfelelően meghatároztuk az MSC kultúra sejtfelszíni markermolekula profilját. $5 \times 10^{5}$ sejtszuszpenzióba vitt MSC-t jelöltünk fluoreszceinizotiocianáttal (FITC) konjugált anti-CD34 és fikoeritrinnel (PE) konjugált anti-CD44, CD73, CD90 és Sca-1 monoklonális ellenanyagokkal (2. táblázat) fél óráig, $4^{\circ} \mathrm{C}$-on és sötétben. A CD3, CD11b, CD45R, Ly6G és TER119 markereket biotinilált elsődleges ellenanyaggal (2. táblázat) jelöltük, majd ezt követően PE-konjugált sztreptavidinnel (Dako) további 30 percig, $4^{\circ} \mathrm{C}$-on és sötétben. A 2. táblázatban szereplő ellenanyagok mind patkányban termeltetett, BD Pharmingen által gyártott immunoglobulinok. A jelölést követően a minták fluoreszcencia intenzitását FACSCalibur áramlási citométerrel (Becton Dickinson) mértük. Az adatok kiértékelését CellQuest ${ }^{\mathrm{TM}}$ (Becton Dickinson) szoftverrel végeztük. 


\begin{tabular}{|c|c|}
\hline Ellenanyag & Jelölés típusa \\
\hline anti-egér Sca-1 & PE-konjugált \\
\hline anti-egér CD3 & biotinilált \\
\hline anti-egér CD11b & biotinilált \\
\hline anti-egér CD34 & FITC-konjugált \\
\hline anti-egér CD44 & PE-konjugált \\
\hline anti-egér CD45R & biotinilált \\
\hline anti-egér CD73 & PE-konjugált \\
\hline anti-egér CD90 & PE-konjugált \\
\hline anti-egér Ly6G & biotinilált \\
\hline anti-egér TER119 & biotinilált \\
\hline
\end{tabular}

\section{2. táblázat}

Az MSC klónok sejtfelszíni markereinek vizsgálatához az MSC-ket sejtszuszpenzióba vittük, és a megfelelő antitestekkel (3. táblázat) inkubáltuk fél óráig, sötétben és $4^{\circ} \mathrm{C}$-on $\left(5 \times 10^{5} \mathrm{sejt} /\right.$ minta $)$. A 3. táblázatban felsorolt elsődleges antitestek szintén patkányban termeltett, BD Pharmingen által gyártott ellenanyagok. A jelölés után mostuk a sejteket immunfluoreszcencia pufferrel (IFB). A konjugálatlan elsődleges ellenanyaggal (anti-CD11b,-CD29,-CD45 és -CD106) jelölt mintákat kecskében termeltetett FITC-konjugált másodlagos ellenanyaggal, a biotinilált anti-CD119-el jelölt mintákat PE- vagy FITC-konjugált sztreptavidinnel (Dako) inkubáltuk fél óráig, sötétben és $4^{\circ} \mathrm{C}$-on. A mintákat mostuk, felvettük IFB-ben, és fluoreszcencia intenzitásukat FACSCalibur áramlási citométerrel (Becton Dickinson) mértük. Az adatok kiértékelését CellQuest $^{\mathrm{TM}}$ (Becton Dickinson) szoftverrel végeztük. A konjugálatlan ellenanyagokkal és a biotin-konjugált ellenanyaggal jelölt mintákhoz elsődleges ellenyanyag nélküli kontrollt, a PE-konjugált ellenanyaggal jelölt mintákhoz festés nélküli kontrollt használtunk.

\begin{tabular}{|c|c|}
\hline Ellenanyag & Jelölés típusa \\
\hline anti-egér Sca-1 & PE-konjugált \\
\hline anti-egér CD11b & konjugálatlan \\
\hline anti-egér CD29 & konjugálatlan \\
\hline anti-egér CD44 & PE-konjugált \\
\hline anti-egér CD45 & konjugálatlan \\
\hline anti-egér CD73 & PE-konjugált \\
\hline anti-egér CD106 & konjugálatlan \\
\hline anti-egér CD119 & biotinilált \\
\hline anti-patkány IgG & FITC-konjugált \\
\hline
\end{tabular}

3. táblázat 


\section{IV.3. In vitro zsírsejt és csontképző sejt irányú differenciáció}

Az MSC-k zsírsejt irányba történő differenciáltatásához a következő médiumot állítottuk össze: DMEM/F-12 $\left(\right.$ Gibco $\left.^{\circledR}\right), 10 \%$ FBS (Gibco $\left.{ }^{\circledR}\right), 100-100 \mu \mathrm{g} / \mathrm{mL}$ penicillinsztreptomicin (PAA), 0,5 mM 3-izobutil-1-metilxantin (IBMX, Sigma-Aldrich), $66 \mu \mathrm{M}$ indometacin (Sigma-Aldrich), $2 \mu \mathrm{L} / \mathrm{mL}$ inzulin (inzulin lispro injekció, $100 \mathrm{U} / \mathrm{mL}$, Humalog $\left.^{\circledR}\right)$ (148). A sejteket 3 napig tartottuk zsírsejt differenciáltató médiumban, majd $0,05 \%$ tripszin-EDTA tartalmú médiummal eltávolítottuk a tenyésztőedény aljáról és $8 \%$ os paraformaldehiddel (Sigma-Aldrich) fixáltuk őket. A zsírsejt differenciációt jelző lipidcseppeket Oil Red O (Sigma-Aldrich) festéssel tettük láthatóvá metilénkék (SigmaAldrich) háttérfestés mellett. A zsírsejt differenciációról CKX41 inverz fénymikroszkóphoz csatlakoztatott Camedia C-5060 kamerával fényképeket készítettünk (Olympus Holding Europa GmbH).

$\mathrm{Az}$ csontképző sejt irányba differenciáltató médium KM-en alapult, melyet kiegészítettünk $10 \mathrm{mM} \beta$-glicerofoszfáttal (Sigma-Aldrich), $50 \mu \mathrm{g} / \mathrm{mL}$ L-aszkorbinsav-2foszfáttal (Sigma-Aldrich) és $0,1 \mu \mathrm{M}$ hidrokortizonnal (Sigma-Aldrich) (17). Az MSC-ket 14 napig tartottuk ebben a médiumban, majd 0,05\% tripszin-EDTA tartalmú médiummal eltávolítottuk a tenyésztőedény aljáról, $8 \%$ formaldehiddel fixáltuk őket, és Alizarin Red S festék (Sigma-Aldrich) oldattal $(\mathrm{pH} \mathrm{4,1)} \mathrm{tettük} \mathrm{láthatóvá} \mathrm{a} \mathrm{csontosodási} \mathrm{gócokban}$ felhalmozódó kálciumot. A csontképző sejt differenciációról CKX41 inverz fénymikroszkóphoz csatlakoztatott Camedia C-5060 kamerával fényképeket készítettünk.

\section{IV.4. Zsírsejt differenciáció vizsgálata AdipoRed ${ }^{\mathrm{TM}}$ reagenssel és citofluorimetriával}

Az MSC-ket 3 napig tartottuk zsírsejt differenciáltató médiumban, majd szuszpenzióba vittük és 4\%-os paraformaldehiddel (Sigma-Aldrich) fixáltuk őket. A zsírsejt differenciációt jelző lipidcseppeket fluoreszcensen jelöltük AdipoRed ${ }^{\mathrm{TM}}$ reagenssel a gyártó által javasolt körülmények mellett (Lonza). A fluoreszcens lipidcseppekről Axioskop 2 Mot fluoreszcens mikroszkóppal (Carl Zeiss) EC Plan-Neofluar 20x/0.5 objektívvel (Carl Zeiss) készítettünk felvételeket. A zsírsejtekben felhalmozódó lipidek mennyiségi meghatározásához a fent leírt módon jelöltük a sejteket AdipoRed ${ }^{\mathrm{TM}}$-del $\left(5 \times 10^{5}\right.$ sejt/minta). A sejtek fluoreszcencia intenzitását FACSCalibur áramlási citométerrel mértük, az adatok kiértékelését CellQuest ${ }^{\mathrm{TM}}$ szoftverrel végeztük. 


\section{IV.5. A növekedés vizsgálata}

$2 \times 10^{4}$ MSC-t ültettünk ki $35 \mathrm{~mm}$ átmérőjű sejttenyésztő csészébe (Greiner), minden számolási napra 2-2 párhuzamossal. A kiültetést követő 2-6. napon 0,05\% tripszinEDTA tartalmú médiummal távolítottuk el a sejteket a tenyésztőedényről, az élő sejtek elkülönítésére a sejteket tripánkék festékoldattal festettük és Bürker kamrában számoltuk. Az MSC klónok populáció kétszereződési idejét (population doubling time, PDT) a következő képlet alapján számoltuk ki:

$$
\mathrm{PDT}=\mathrm{t} 2-\mathrm{t} 1 \div[(\log \mathrm{n} 2-\log \mathrm{n} 1) \times 3.32]
$$

ahol t1 és t2 a kiültetéstől eltelt idő (óra) két külön számolási időpontban, melyek között a sejtek növekedése lineáris fázisban volt, $\mathrm{n} 1$ és $\mathrm{n} 2$ pedig a sejtszám $\mathrm{t} 1$, illetve $\mathrm{t} 2$ időpontban. A PDT tehát megadja, hogy az adott sejtpopuláció sejtszáma mennyi idő alatt duplázódik meg.

\section{IV.6. In vitro prevascularis struktúra teszt}

A prevascularis teszt során az MSC-ket és a H5V (155) egér szív endotélsejteket (mely utóbbit Dr. Vizler Csaba ajándékozott csoportunknak, MTA SZBK, Biokémiai Intézet) 24-lyukú sejttenyésztő lemezen együtt-tenyésztésbe (kokultúrába) vontunk. A kokultúrában a sejtek aránya $1: 1$ volt, a sejtszám pedig külön-külön $2 \times 10^{4} /$ lyuk. Kontrollként egyező számú, monokultúrában tartott sejteket használtunk. A kokultúra 3. napján 5 véletlenszerüen kiválasztott, nem átfedő látómezőt lefényképeztünk Olympus Cell-R fluoreszcens mikroszkóppal (Olympus Holding Europa $\mathrm{GmbH}$ ), melyhez UPlanSApo 4x/0.16 objektívet használtunk. A fényképeken a prevascularis struktúrák hosszát CellR Imaging szoftver segítségével becsültük meg (Olympus Holding Europa $\mathrm{GmbH})$.

\section{IV.7. In vitro T-sejt proliferációs teszt}

Kilencvenhat-lyukú lemezre lyukanként $1,25 \times 10^{3}-2 \times 10^{4}$ MSC-t szélesztettünk $100 \mu \mathrm{L}$ KM-ben, az MSC sejtszámot az egyes kísérletekhez tartozó ábraaláírásban tüntettük fel. Balb/C egérből izoláltuk a mesenterialis, inguinalis és brachialis nyirokcsomókat, melyeket hibridóma lapáttal RPMI $\left(\right.$ Gibco $\left.^{\circledR}\right)$ médiumban 
szétnyomkodtunk, ezáltal a bennük lévő leukocitákat felszabadítottuk a médiumba. Egyes kísérletekhez az így nyert leukocitákból T-sejteket szeparáltunk. A leukocitákat vagy szeparált T-sejteket centrifugálással összegyüjtöttük, 5\% FBS-t tartalmazó foszfáttal pufferelt fiziológiás sóoldatban (PBS) szuszpendáltuk úgy, hogy a sejtkoncentráció $2 \times 10^{6}$ sejt/mL volt. A leukocitákhoz $2,5 \mu \mathrm{M}$ koncentrációban karboxifluoreszcein-diacetátszukcimidilésztert (CFSE, CellTrace ${ }^{\mathrm{TM}}$ CFSE Cell Proliferation Kit, Life Technologies) adtunk, és a sejteket szobahőmérsékleten, sötétben 5 percig inkubáltuk. Ezt követően a sejteket RPMI-vel kétszer mostuk, és a már kiültetett MSC-hez lyukanként $2 \times 10^{5}$ leukocitát adtunk $100 \mu \mathrm{L} \quad 10 \% \quad$ FBS-t, $50 \mu \mathrm{M} \quad \beta$-merkaptoetanolt (Sigma-Aldrich) tartalmazó RPMI médiumban. Így a kokultúra össztérfogata $200 \mu \mathrm{L}$ volt. A leukociták aktivációját a kokultúrához adott $5 \mu \mathrm{g} / \mathrm{mL}$ Concanavalin A (ConA, Sigma-Aldrich) növényi lektinnel, a szeparált T-sejtek aktivációját anti-CD3/CD28 ellenanyaggal (Dynabeads, Invitrogen) végeztük. Specifikus inhibítorokkal végzett kísérletekben a nitrogén-monoxid szintáz 2 (NOS2), a prosztaglandin-endoperoxid szintáz 2 (PTGS2) vagy az indolamin-2,3-dioxigenáz (IDO) enzim müködését $1 \mathrm{mM}$ NG-metil-L-argininacetáttal (L-NMMA, Sigma-Aldrich), $10 \mu \mathrm{M}$ indometacinnal (Sigma-Aldrich), illetve $1 \mathrm{mM}$ 1-metil-triptofánnal (1-MT, Sigma-Aldrich) gátoltuk. Hetvenkét óra elteltével a le nem tapadó leukocitákat PBS-sel mostuk, és felvettük őket $10 \mu \mathrm{g} / \mathrm{mL}$ propídium-jodiddal (Sigma-Aldrich) kiegészített IFB-ben. A sejtek fluoreszcencia intenzitását FACSCalibur áramlási citométerrel mértük, az adatok kiértékelését ModFit $\mathrm{LT}^{\mathrm{TM}}$ Version 2.0. szoftverrel (Verity Software House, Inc) végeztük.

Egyes kísérletekben az MSC-ket 24 óráig $100 \mathrm{ng} / \mathrm{mL}$ egér rekombináns IFN- $\gamma$-val (R\&D Systems) és $50 \mathrm{ng} / \mathrm{mL}$ TNF- $\alpha$-val előkezeletük (melyet Dr. Vizler Csabától, az MTA SZBK Biokémiai Intézetéből kaptunk) (156). A kezelést követően a sejteket kétszer KM-mel mostuk, majd a T-sejt proliferációs tesztet a fent leírtak alapján vittük véghez.

\section{IV.8. T-sejt szeparáció és aktiválás}

Balb/C egérből a fennt leírt módon izoláltuk a mesenterialis, inguinalis és brachialis nyirokcsomókat. Az így nyert leukocitákból T-sejteket szeparáltunk BD IMagTM T lymphocyte Enrichment Set DM kit és IMagnet ${ }^{\mathrm{TM}}$ készülék segítségével (BD Biosciences). Ehhez először a sejteket $\left(2 \times 10^{6} / \mathrm{mL}\right)$ PBS-ben szuszpendáltuk, és hozzáadtuk a biotinilált monoklonális ellenanyag koktélt $\left(5 \mu \mathrm{L} / 10^{6}\right.$ leukocita), mely a T-sejtektől különböző leukocitákat ismeri fel. A sejteket 15 percig, sötétben és jégen inkubáltuk. A jelölés után a 
sejteket mostuk, centrifugálással ülepítettük, és hozzáadtuk a gyártó által biztosított sztreptavidinnel borított mágneses részecskéket $\left(5 \mu \mathrm{L} / 10^{6}\right.$ leukocita). Erőteljes keverés után a sejteket fél óráig $4^{\circ} \mathrm{C}$-on tartottuk. A sejteket tartalmazó Falcon csövet 8 percre a BD IMagnet ${ }^{\mathrm{TM}}$ mágneses készülékre helyeztük. A T-sejteket tartalmazó felülúszót összegyüjtöttük, és a mágneses részecskékhez új médiumot adtunk. Megismételtük még egyszer a mágneses szeparálást, és a felülúszót az előzőhöz hozzáadtuk.

A szeparált T-sejtek aktivációjához a sejteket $\left(2 \times 10^{5} /\right.$ lyuk $)$ kitettük 96-lyukú sejttenyésztő lemezre, és hozzáadtunk $2 \mu \mathrm{L} /$ lyuk anti-CD3/CD28 ellenanyaggal borított mágneses gyöngyöt (Dynabeads, Invitrogen).

\section{IV.9. Citokinmérés felülúszóból}

Balb/C egérből a fennt leírt módon izoláltuk a mesenterialis, inguinalis és brachialis nyirokcsomókat. Az így nyert leukocitákból T-sejteket szeparáltunk és a sejteket a fent leírt módon 72 órán keresztül anti-CD3/CD28 ellenanyagokkal aktiváltuk. Hetvenkét óra múlva a T-sejtek felülúszóját összegyüjtöttük.

Az IL-2,4,5, IFN- $\gamma$ és a TNF- $\alpha$ fehérjék detektálását a Cytometric Bead Array és Mouse Th1/Th2 Cytokine kit (BD Biosciences) segítségével végeztük mintánként $50 \mu \mathrm{L}$ felülúszóból. Az $50 \mu \mathrm{L}$ felülúszóhoz hozzáadtuk a gyöngyökhöz kovalensen kötött, PEkonjugált anti-IL-2, -IL-4, -IL-5, -IFN- $\gamma$ és anti-TNF- $\alpha$ ellenanyagokat tartalmazó oldatot és a detektációs reagenst. Két órán keresztül inkubáltuk sötétben és szobahőn. Ezt követően a gyöngyöket mostuk, centrifugálással ülepítettük, mosópufferben felvettük, és fluoreszcencia intenzitásukat FACSCalibur áramlási citométerrel mértük. Az adatok kiértékelését CellQuest $^{\mathrm{TM}}$ szoftverrel végeztük. A felülúszókban a citokinek mennyiségét a gyártó által biztosított sztenderd sor alapján kalibráltuk.

\section{IV.10. Western blot analízis}

Az MSC-ket RIPA pufferben lizáltuk ( $10^{7} \mathrm{MSC} / \mathrm{mL}$ puffer). A lizátumot 10\%-os SDS-poliakrilamid gélen Page Ruler ${ }^{\mathrm{TM}}$ elöre festett fehérje molekulasúly marker mellett (Fermentas) futtattuk, majd az elválasztott fehérjéket elektromos árammal (20V feszültséggel, 16 órán át és $4^{\circ} \mathrm{C}$-on) nitrocellulóz membránra (Whatman ${ }^{\circledR} \operatorname{Protran}^{\circledR}$ ) transzferáltuk. A membránt 1 órán keresztül 3\% zselatint (Sigma-Aldrich) és 0,05\% Tween $^{\circledR}$ 20-at tartalmazó (Sigma-Aldrich) Tris pufferelt sóoldatban (TBST) szobahőn telítettük. A membrán szabad kötőhelyeinek telítése után $4^{\circ} \mathrm{C}$-on 1-1 órán keresztül a 
laborunkban elöállított 2500× hígított nyúl anti-Gal-1 ellenanyaggal (71), majd 3× TBST mosás után 3000× hígított HRP-konjugált anti-nyúl immunoglobulinnal (Dako) inkubáltuk a membránt. Felviteli kontrollként $10000 \times$ hígított nyúl anti- $\beta$-aktin ellenanyagot használtunk (Abcam). Az immunreaktív fehérjéket kemilumineszcens Amersham ${ }^{\mathrm{TM}} \mathrm{ECL}$ Prime reagenssel (GE Healthcare Life Sciences) hívtuk elő, és CCD Chemi 410 kamerával felszerelt EC3 Imaging System munkaállomás segítségével készítettünk róla felvételt (Ultra-Violet Products). A felvételen a sávok denzitását VisionWorks ${ }^{\circledR}$ LS Image Acquisition and Analysis szoftverrel (Ultra-Violet Products) analizáltuk.

\section{IV.11. Kvantitatív valós idejü (real-time) polimeráz láncreakció (qRT-PCR)}

Az MSC-t (10\% $/$ minta) $35 \mathrm{~mm}$ átmérőjü sejttenyésztő csészébe KM médiumba ültettük ki. Másnap a médiumot $100 \mathrm{ng} / \mathrm{mL}$ IFN- $\gamma$-val és $50 \mathrm{ng} / \mathrm{mL}$ TNF- $\alpha$-val kiegészített friss KM-re cseréltük, és a sejteket további 24 óráig inkubáltuk. Kontrollként azonos időben kiültetett, KM médiumban tartott sejteket használtunk. Az inkubációs idő leteltével totál RNS-t izoláltunk az MSC-ből Nucleospin RNA II kittel (MACHEREY-NAGEL $\mathrm{GmbH})$ a gyártó utasításai szerint. A másolati DNS (cDNS) átírását RevertAid H Minus cDNS szintézis kittel (Thermo Fisher Scientific) végeztük $2 \mu \mathrm{g}$ totál RNS-ből kiindulva a gyártó utasításai szerint. A qRT-PCR-t Rotor Gene3000 készülékben (Corbett Life Science) végeztük. A PCR reakcióhoz a Ptgs2, Nos2 és Idol gének esetén TaqMan ${ }^{\circledR}$ univerzális génexpressziós master mixet (Life Technologies), az angiopoietin-1 (Angpt1), Vegfa, Tgfb1, galektin-1 (Lgals1), Runt-szerü transzkripciós faktor-2 (Runx2), csont Gla fehérje (bone gla protein, Bglap) és szekretált foszfoprotein-1 (Sppl) gének esetén AccuPower $^{\circledR} 2 \mathrm{X}$ Greenstar qPCR master mixet (Bioneer) használtunk. A vizsgált gén (GOI) expresszióját a glicerinaldehid-3-foszfát-dehidrogenáz (Gapdh) referencia gén kifejeződéséhez viszonyítottuk oly módon, hogy a vizsgált gén relatív expresszióját a referencia génhez képesti áttörési ciklusaik $(\mathrm{Ct})$ különbségeként $(\Delta \mathrm{Ct})$ ábrázoltuk: $\Delta \mathrm{Ct}=\mathrm{Ct}_{\text {Gapdh }}-\mathrm{Ct}_{\text {GOI. }}$. A relatív mRNS különbségeket a $2^{\Delta \Delta \mathrm{Ct}}$ képlet alkalmazásával kaptuk, ahol a $\Delta \Delta \mathrm{Ct}=\left(\mathrm{Ct}_{\text {Gapdh }}-\mathrm{Ct}_{G O I}\right)_{\text {egyik MSC klón }}-\left(\mathrm{Ct}_{\text {Gapdh }}-\mathrm{Ct}_{G O I}\right)_{\text {másik MSC klón a klónok }}$ génexpressziós szintjének meghatározása esetén, vagy $\Delta \Delta \mathrm{Ct}=\left(\mathrm{Ct}_{\text {Gapdh }}-\mathrm{Ct}_{G O I}\right)_{\text {kezelt }}-$ $\left(\mathrm{Ct}_{\text {Gapdh }}-\mathrm{Ct}_{G O I}\right)_{\text {kontroll }}$ a génexpressziós változás környezeti vizsgálatakor. A Ptgs 2 (Mm00478374_m1), Nos2 (Mm01309902_m1), Ido1 (Mm00492586_m1*) és Gapdh (Mm99999915_g1) gének vizsgálatához kereskedelmi forgalomban lévő TaqMan ${ }^{\circledR}$ génexpressziós próbákat vásároltunk, míg az Angpt1, Bglap, Gapdh, Lgals1, Runx2, Spp1, 
$T g f b 1$ és $V e g f a$ génekhez a Roche által ingyenesen hozzáférhetővé tett Universal Probe Library Assay Design program alapján terveztünk primereket (4. táblázat).

\begin{tabular}{|c|c|c|}
\hline Gén & Primer & Szekvencia \\
\hline \multirow[t]{2}{*}{ Angpt1 } & forward & 5'-cggatttctcttcccagaaac-3' \\
\hline & reverz & 5'-tccgacttcatattttccacaa-3' \\
\hline \multirow[t]{2}{*}{ Bglap } & forward & 5'-agactccggcgetacctt-3' \\
\hline & reverz & 5'-ctcgtcacaagcagggttaag-3' \\
\hline \multirow[t]{2}{*}{ Gapdh } & forward & 5'-tttgatgttagtggggtctcg-3' \\
\hline & reverz & 5'-agcttgtcatcaacgggaag-3' \\
\hline \multirow[t]{2}{*}{ Lgals1 } & forward & $5^{\prime}$-ctctcgggtggagtcttctg-3' \\
\hline & reverz & 5'-ggtttgagattcaggttgctg-3' \\
\hline \multirow[t]{2}{*}{ Runx 2} & forward & 5'-agtagccaggttcaacgatctga-3' \\
\hline & reverz & 5'-gactgttatggtcaaggtgaaactctt-3' \\
\hline \multirow[t]{2}{*}{ Sppl } & forward & 5'-ggaggaaaccagccaagg-3' \\
\hline & reverz & 5'-tgccagaatcagtcactttcac-3' \\
\hline \multirow[t]{2}{*}{$T g f b l$} & forward & 5'-tggagcaacatgtggaact-3' \\
\hline & reverz & 5'-cagcagccggttaccaag-3' \\
\hline \multirow[t]{2}{*}{$V e g f a$} & forward & 5'-aaaaacgaaagcgcaagaaa-3' \\
\hline & reverz & 5'-tttctccgctctgaacaagg-3' \\
\hline
\end{tabular}

4. táblázat

\section{IV.12. Késői típusú túlérzékenységi reakció kiváltása}

A késői típusú túlérzékenységi reakció (Delayed Type Hypersensitivity, DTH) kiváltásához antigénként csirke tojásfehérje albumint, ún. ovalbumint (OVA, SigmaAldrich) használtunk. A kísérlet menetét a 4.ábra szemlélteti. A szenzibilizációhoz $1 \mathrm{mg} / \mathrm{mL}$ koncentrációban oldottunk OVA-t PBS-ben, és komplett Freund-adjuvánssal (CFA, Sigma-Aldrich) $1: 1$ arányban emúlziót készítettünk. Hat-nyolc hetes hím C57BL/6 egereket immunizáltunk állatonként $100 \mu \mathrm{g}$ OVA-t tartalmazó emúlziót oltva az állatok bőre alá. Kontrollként CFA-val emúlzionált PBS-t oltottunk. Ezt követően állatonként $10^{6}$ MSC-t $200 \mu$ L PBS-ben oltottunk az állatok hasüregébe. Az MSC-vel nem oltott állatokba $200 \mu$ L PBS-t oltottunk. Négy nap múlva a DTH reakció kiváltásához az állatok jobb hátsó talppárnájába 12,5 $\mu \mathrm{L}$ PBS-ben oldott $250 \mu \mathrm{g}$ hőaggregált ovalbumint oltottunk, a kontroll bal hátsó talpárnájába pedig 12,5 $\mu$ L PBS-t. A talppárnák oltását közvetlenül megelőzően, illetve 48 órával az oltás után mértük a talppárnák vastagságát mindkét hátsó lábon. $\mathrm{Az}$ ovalbumin átal kiváltott DTH reakció során fellépő talppárna relatív duzzanatát $(\mathrm{RD})$ a 
következő képlet alapján számítottuk: $\mathrm{RD}=\left(\mathrm{J}_{48}\right.$ óra $-\mathrm{B}_{48}$ óra $)$ - $\left(\mathrm{J}_{0}\right.$ óra $-\mathrm{B}_{0}$ óra $)$, ahol J az OVAval oltott jobb hátsó talppárna vastagságát, B a PBS-sel oltott bal hátsó talppárna vastagságát jelenti mm-ben megadva.

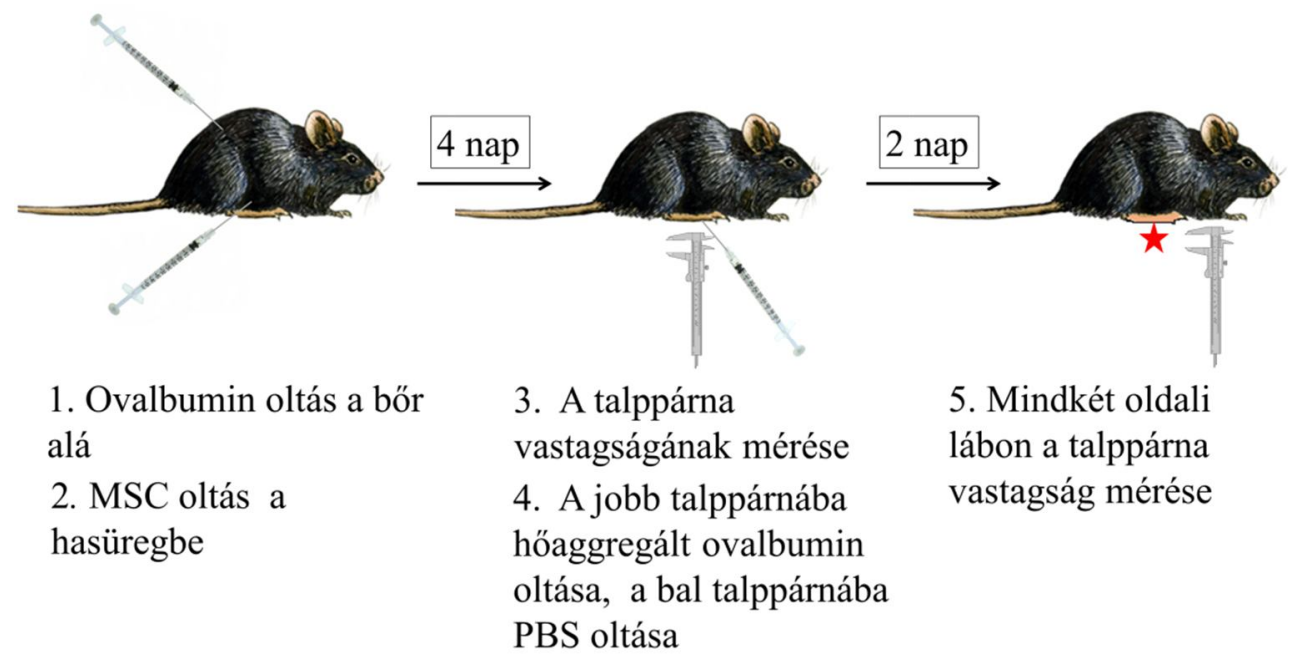

\section{4. ábra. A DTH kísérlet menete}

\section{IV.13. Statisztikai elemzés}

Az eremények statisztikai elemzéséhez a GraphPad Prism 6.03 (GraphPad Software) szoftvert használtuk. Azoknál a kísérleteknél (az összes, kivéve 24. ábra), melyek több kísérleti csoportból álltak, az adatokon egyutas varianciaanalízist végeztünk (Analysis of Variance, ANOVA). Abban az esetben, ha az ANOVA szignifikáns különbséget mutatott $(\mathrm{p}<0,05)$, akkor az egyes kísérleti csoportok közötti különbségek többszörös összehasonlításához a Fisher-féle Legkissebb Szignifikáns Különbség (least significant difference, LSD) post hoc tesztet végeztünk. A 24. ábránál, mely csak két kíséleti csoportot tartalmazott a Student-féle T-tesztet alkalmaztuk. Egy különbséget statisztikailag akkor tekintettünk szignifikánsnak, ha a p érték kisebb volt mint 0,05 $(*: \mathrm{p}<0,05 ; * *: \mathrm{p}<0,01 ; * * *: \mathrm{p}<0,001)$. Az ábrákon több kísérletben nyert adatok átlagát jelenítettük meg, és megadtuk az adatok standard eltérését (standard deviáció, SD) vagy az átlag standard hibáját (standard error of the mean, SEM). 


\section{Eredmények}

\section{V.1. Az MSC-k jellemzése}

V.1.a. Sejtfelszíni markerek vizsgálata

A klónozatlan, heterogén MSC kultúra nem rendelkezik vérsejtfejlődési sorokra jellemző CD3, CD11b, CD34, CD45R, Ly6G és TER119 és más sejtvonalakra jellemző specifikus sejtfelszíni markermolekulákkal, ellenben hordozza az MSC-kre jellemző CD44, CD73, CD90 és Sca-1 molekulákat (5. ábra). Az eredmények értelmében a kultúra sejtfelszíni markerek alapján MSC-nek nevezhető.

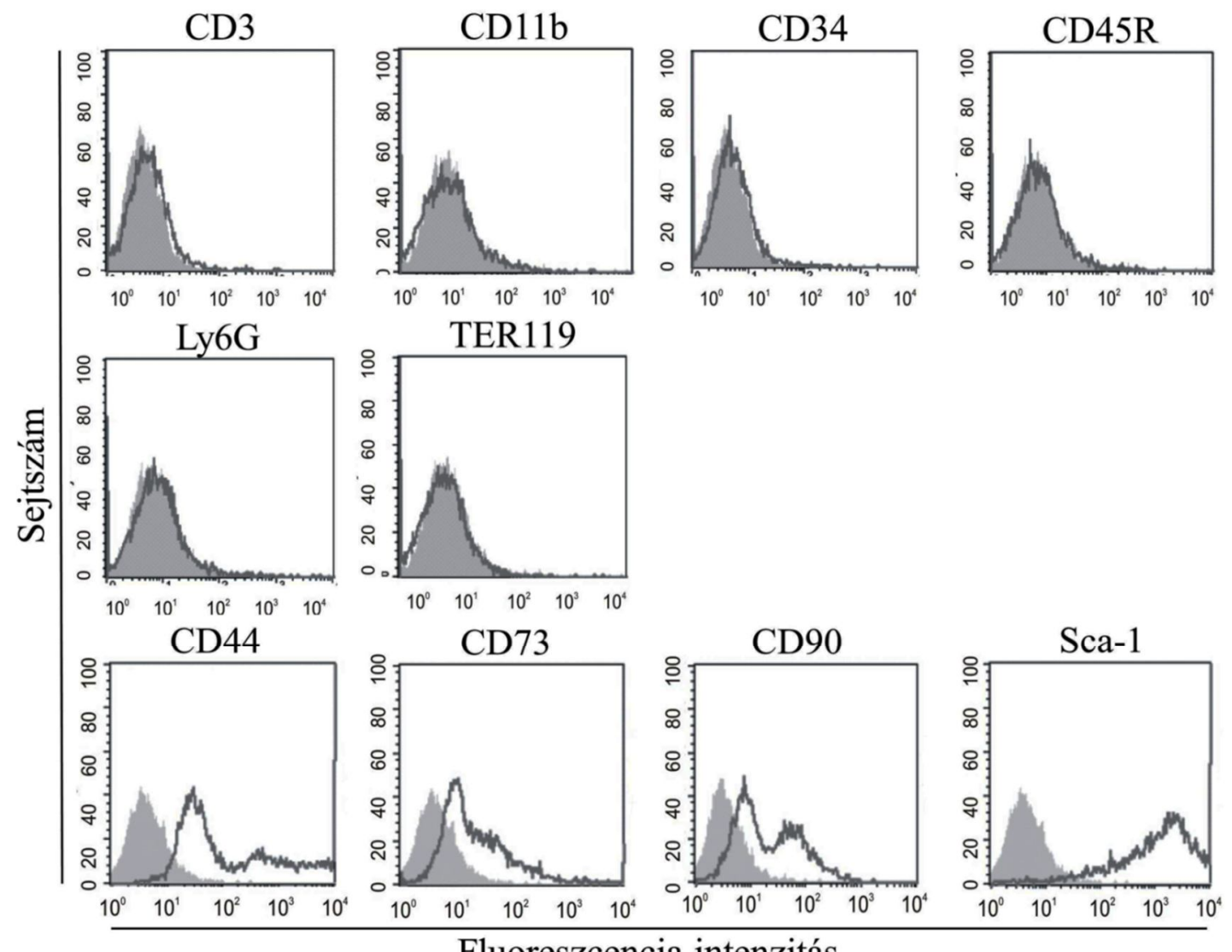

5. ábra. Az MSC kultúra sejtfelszíni markermolekulái. Az MSC-t anti-CD3, CD11b, CD45R, Ly6G, TER119, CD44, CD73, CD90 és anti-Sca-1 ellenanyagokkal (sötét vonal) jelöltük, és áramlási citometriával mértük a sejtek fluoreszcencia intenzitását. A CD34, CD44, CD73, CD90 és Sca-1 jelölés negatív kontrolljaként nem festett sejteket használtunk (szürke hisztogram), míg a CD3, CD11b, CD45R, Ly6G és TER119 jelölés negatív kontrollja az elsödleges ellenanyag nélkül adott PE-konjugált sztreptavidin volt (szürke hisztogram). 
Az MSC kultúrából hígításos módszerrel egy sejt eredetü klónokat hoztunk létre (MSC2-6). A kiindulási MSC kultúrához hasonlóan egyik MSC klón sem hordozta a vérsejtfejlődési sorokra jellemző CD11b és CD45 markereket, mindazonáltal mindegyik klón 100\%-ban kifejezte az MSC-kre jellemző CD73, Sca-1, CD29, CD44, CD106 és CD119 markereket. A CD73 alacsonyan, míg a Sca-1, CD29, CD44, CD106 és CD119 magasan fejeződött ki a sejtek felszínén (6. ábra).

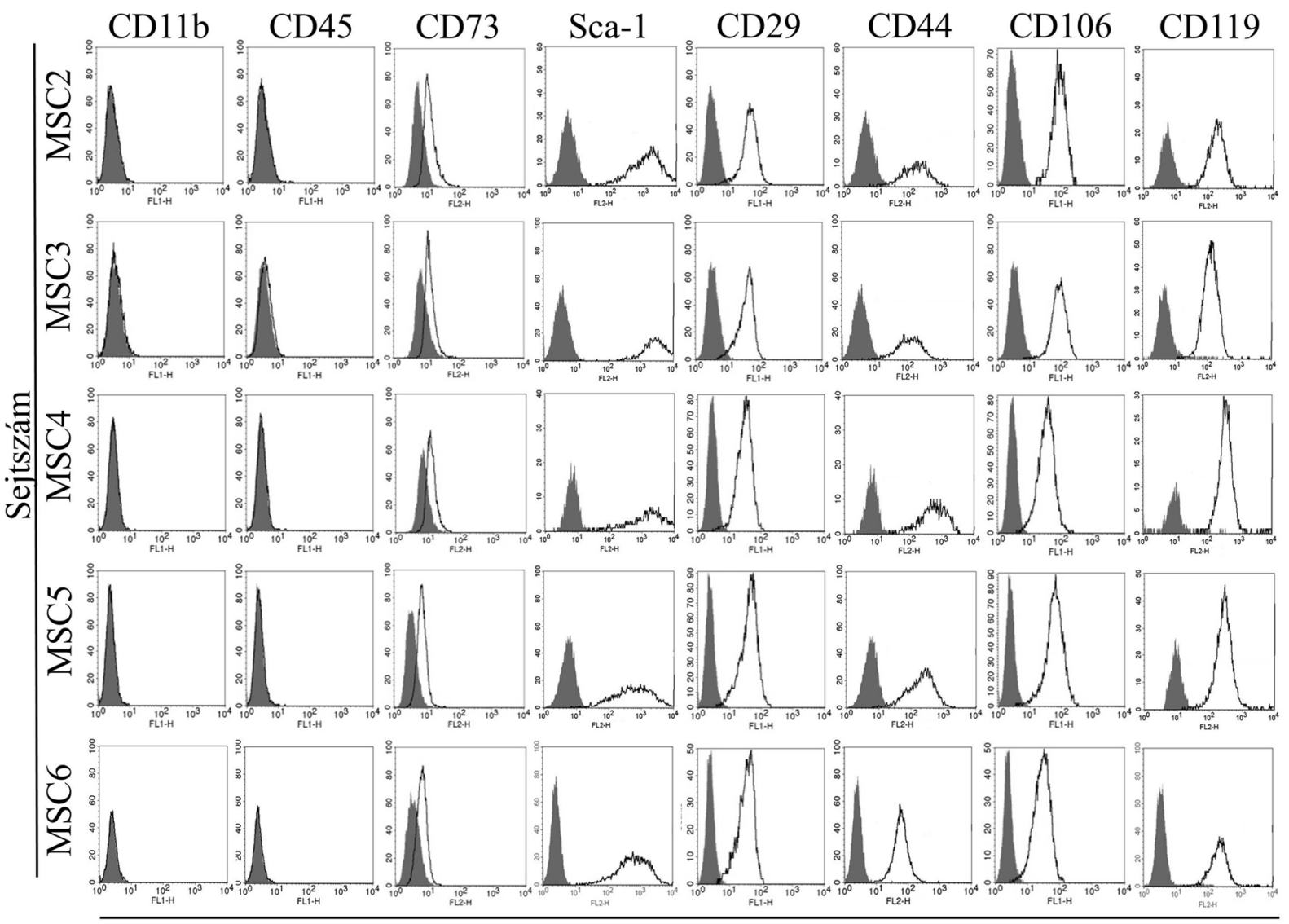

Fluoreszcencia intenzitás

6. ábra. A monoklonális MSC vonalak sejtfelszíni markermolekulái. Az MSC2-6 klónokat anti-CD11b, -CD45-CD73, -Sca-1, -CD29, -CD44, -CD106 és anti-CD119 ellenanyagokkal (fekete vonal) jelöltük, és áramlási citometriával analizáltuk a sejteket. A CD73, Sca-1, CD44 és CD119 jelölés negatív kontrolljaként nem festett sejteket használtunk (szürke hisztogram), míg a CD11b, CD45, CD29 és CD106 jelölés negativ kontrollja az elsödleges ellenanyag nélkül adott másodlagos ellenanyag volt (szürke hisztogram). 
V.1.b. Morfológia és növekedési tulajdonságok

Az MSC2-MSC6 klónok az MSC-kre jellemző 100\% sejtdenzitású (konfluenciájú) kultúrában fibroblaszt-szerü, kitapadó, megnyúlt, orsó alakú sejtek (nincs bemutatott adat), alacsonyabb sejtdenzitás esetén kiterülő, hosszú nyúlványokat képező sejtek (7./A ábra). Az MSC klónok átlagos populáció kétszereződési ideje 16 és 21 óra között változott (7/B. ábra).

A

MSC2

MSC3

MSC4
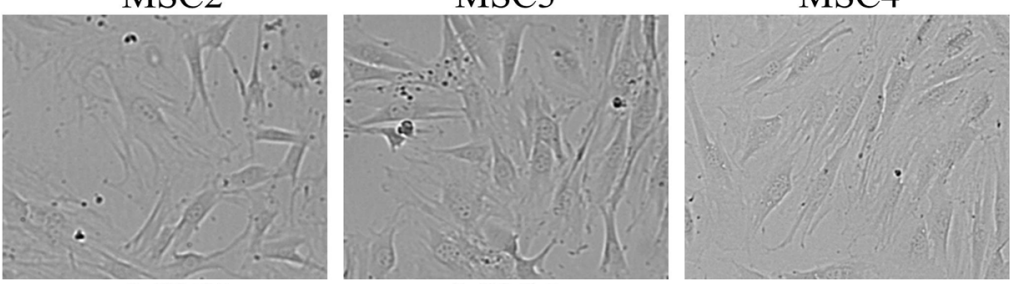

MSC5

MSC6
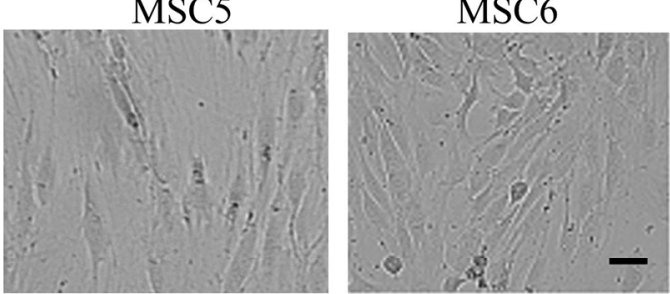

B

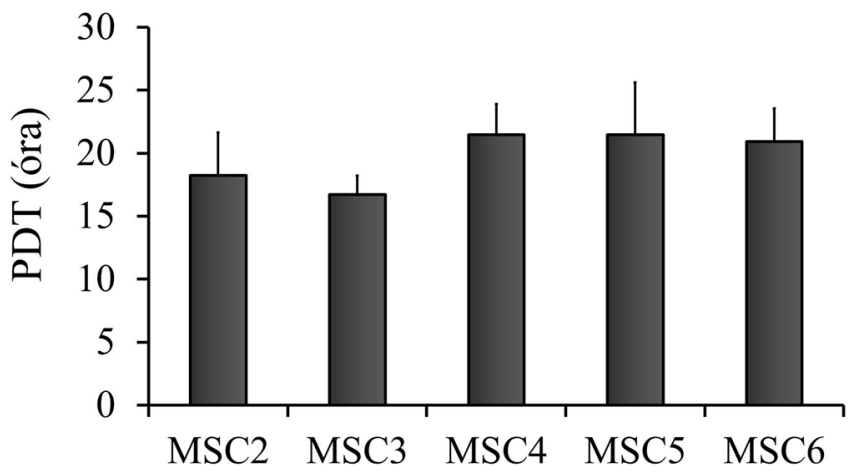

7. ábra. Az MSC klónok morfológiája és növekedése. A.) $2 \times 10^{4}$ MSC-t ültettünk ki 24lyukú lemezre, és 2 napig KM médiumban növesztettük öket, majd a sejteket Olympus Cell$R$ fluoreszcens mikroszkóphoz csatlakoztatott kamerával fényképeztük. Mérce $=50 \mu M . B$.) $2 \times 10^{4}$ MSC-t ültettünk ki 35 mm átméröjü Petri-csészébe. A kiültetést követö 2.-6. napon felszedtük és számoltuk a sejteket. A növekedési görbe lineáris fázisában mért sejtszámokból a az Anyagok és módszerek IV.5. alfejezetében szereplö képlet alapján számítottuk a sejtek PDT-jét ( $t 1=48$ óra; $t 2=96$ óra). A grafikon 2-2 párhuzamossal végzett 2 független kisérlet átlagát $(+S D)$ mutatja be. 
V.1.c. In vitro csontképző és zsírsejt irányú differenciálódás

A klónozatlan heterogén MSC kultúra in vitro csontképző sejt irányú differenciálódását speciális faktorokkal indukáltuk. A sejtek csontosodási gócokba tömörültek és kálciumban gazdag ún. mineralizált extracelluláris mátrixproteineket termeltek. A 14 nap alatt kialakuló csontosodási gócok Alisarin Red S-sel barnásvörösen festődnek (8. ábra).

A zsírsejt irányú differenciálódást stimuláló faktorok jelenlétében az MSC kultúra 3 nap alatt kerekded, lipidcseppekkel teli sejtekké alakult. A lipidcseppeket Oil Red O festéssel tettük láthatóvá (8. ábra).

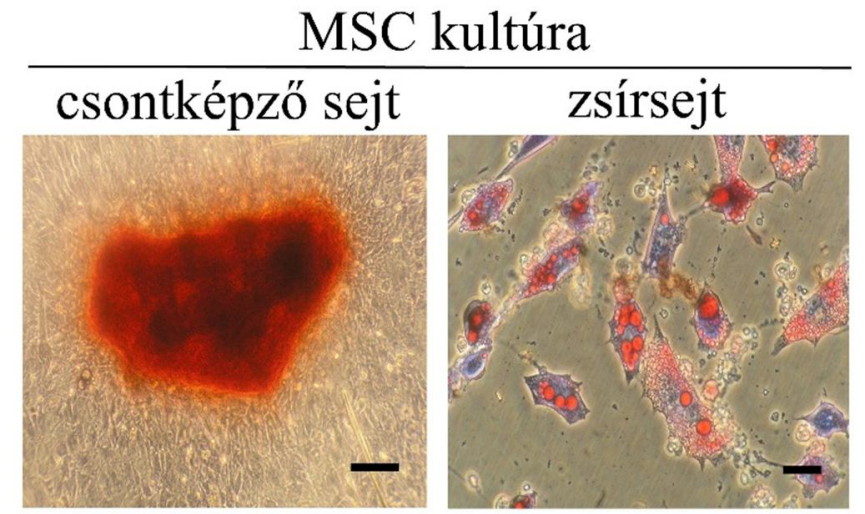

8. ábra. Az MSC kultúra in vitro csontképzö sejt és zsírsejt irányú differenciációja. Az in vitro csontképzö sejt irányba differenciáltatott MSC kultúrákban a differenciáció 14. napján a csontosodási gócokban felhalmozódó kálciumot Alisarin Red S-sel megfestettük (bal oldali kép). A zsírsejt irányba differenciáltatott MSC-ben a kialakuló lipidcseppeket a 3. napon Oil Red O festékkel láthatóvá tettük (jobb oldali kép). A csontképzö sejt és zsirrsejt differenciációról CKX41 mikroszkóphoz kapcsolt Olympus Camedia C-5060 kamerával készitettünk fényképeket. Mérce $=50 \mu \mathrm{M}$

Speciális faktorokkal az MSC klónok in vitro csontképző sejt differenciációja indukálható volt, az indukciót követő 14. napon Alisarin Red S festés alapján a csontosodási gócok mindegyik klón esetén megjelentek, az MSC2, MSC4 és MSC5 erőteljes, míg az MSC3 és MSC6 gyenge in vitro csontképző sejt differenciációt mutatott (9/A. ábra). 
Az MSC klónok mindegyike differenciáltatható volt zsírsejt irányba (9/B. ábra). A klónok differenciálódási képességét a specifikus AdipoRed ${ }^{\mathrm{TM}}$ lipidcsepp festéssel mennyiségileg összevethetővé tettük. A festés alapján a klónok differenciálódási képessége egyforma volt, mivel a fluoreszcensen festett zsírsejtekben felhalmozódó lipidek áramlási citométerrel történő detektálása azt mutatta, hogy az egyes klónok közel azonos mennyiségü neutrális lipidet halmoztak fel a differenciáció folyamán (9/C. ábra).
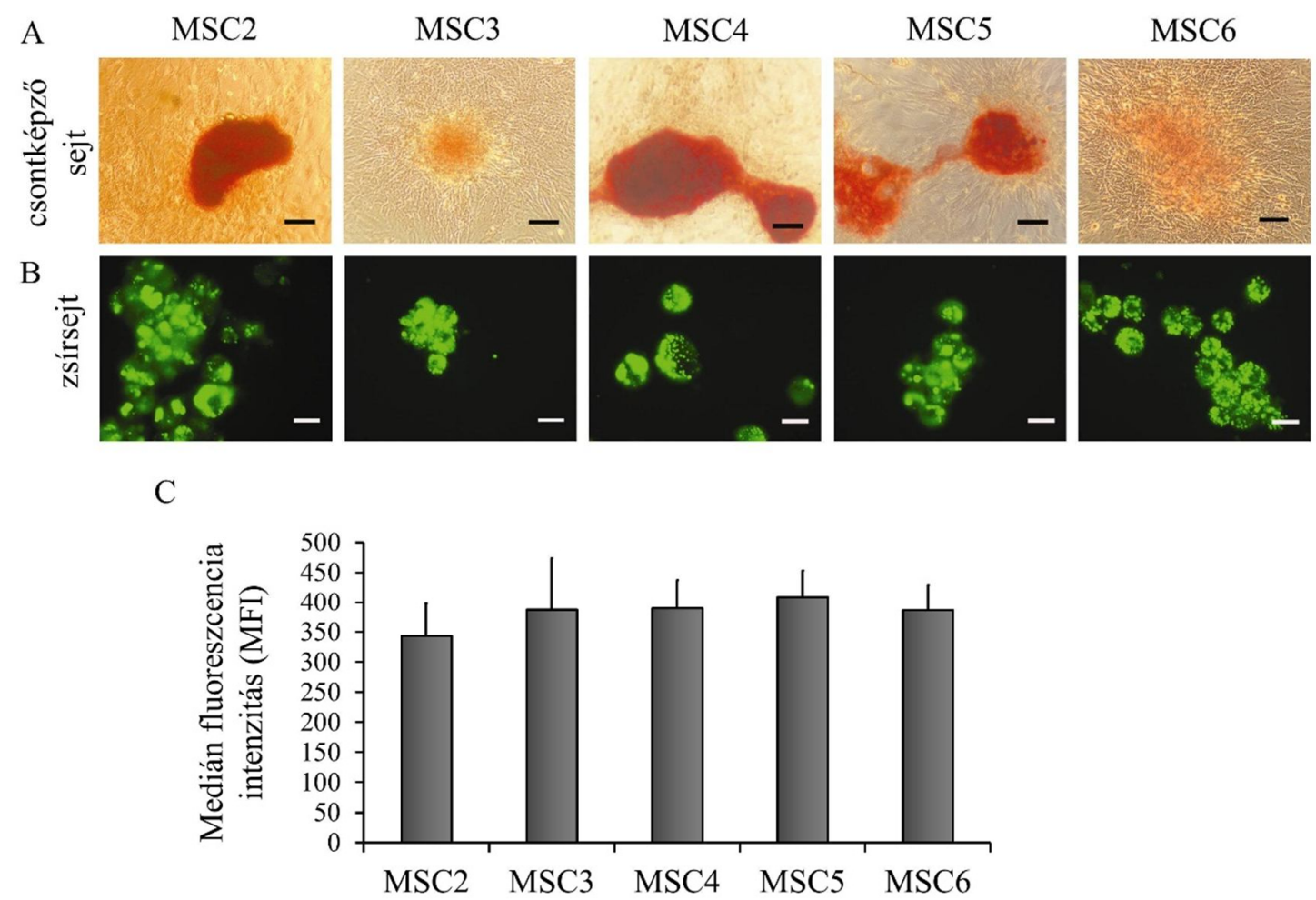

9. ábra. Az MSC klónok in vitro csontképzö sejt és zsírsejt irányú differenciációja. A.) Az in vitro csontképzö sejt irányba differenciáltatott MSC klónokban a differenciáció 14. napján Alisarin Red S-sel megfestettük a csontosodási gócokban felhalmozódó kálciumot. A gócokról CKX41 mikroszkóphoz kapcsolt Olympus Camedia C-5060 kamerával készitettünk fényképeket. B.) A zsírsejt irányba differenciáltatott MSC-ben a 3. napon AdipoRed ${ }^{\mathrm{TM}}$ fluoreszcens festékkel láthatóvá tettük a kialakuló lipidcseppeket és Axioskop 2 Mot fluoreszcens mikroszkóppal lefényképeztük a sejteket. Mérce $=50 \mu M$. C.) $A$ fluoreszcensen jelölt zsirsejtekben felhalmozott lipidek mennyiségét áramlási citometriával (FACSCalibur) hasonlítottuk össze. A grafikon 5 független kísérlet átlagát (+SD) jeleníti meg. 


\section{V.1. d. In vitro proangiogén hatás}

Az MSC-k az endotélsejtekkel kapcsolatban lévő periendotelialis sejtek előalakjának tekinthetők (21). Az endotél- és periendotelialis sejtek kölcsönhatásának vizsgálatára laborunkban egy olyan módszert állítottunk be, mely során a vad típusú klónozatlan, heterogén MSC-t és H5V egér szív endotélsejteket együtt-tenyésztünk (kokultúra). Különböző sejtarányok (MSC : endotélsejt $=5: 1,1: 1,1: 5)$ közül az $1: 1$ arány bizonyult a legoptimálisabbnak. A kokultúra során az $1: 1$ arányban lévő MSC és endotélsejtek 3 nap alatt spontán módon sajátos hálózatokba, ún. prevascularis struktúrákba rendeződtek össze (10. ábra). A struktúrák létrehozásában mindkét sejttípus egyaránt részt vett, ugyanakkor önmagában az MSC kultúra és a H5V nem képzett struktúrákat (10. ábra). Kimutattuk, hogy az MSC-k által termelt proangiogén lektin, a Gal1 meghatározó faktor a prevascularis struktúrák kialakulásában, ugyanis a Gal-1-deficiens MSC szignifikánsan kisebb mértékben támogatja a H5V-vel alkotott struktúrák képződését (71).
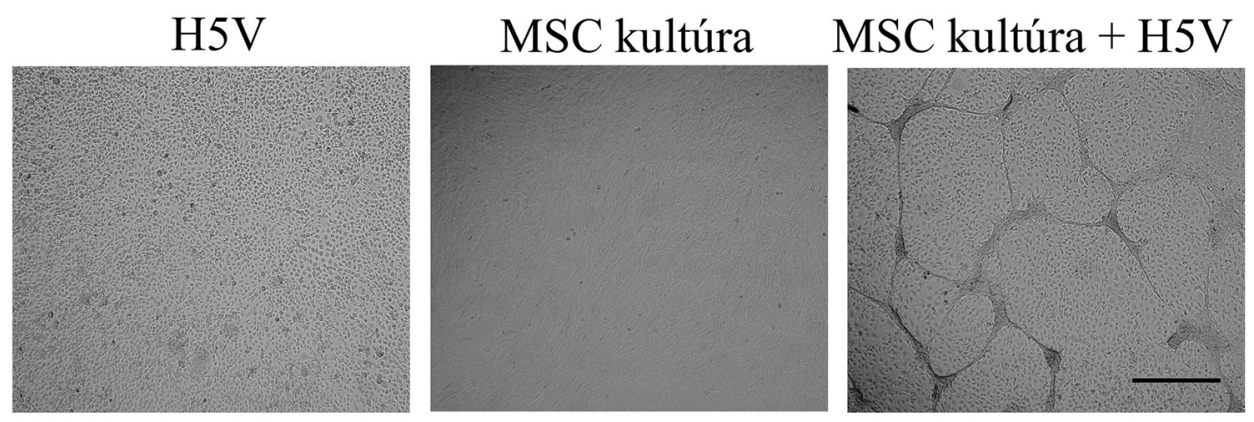

10. ábra. Az MSC-k támogatják a prevascularis struktúrák képződését. $2 \times 10^{4} M S C$-t és $2 \times 10^{4}$ H5V-t 3 napig tenyésztettünk együtt. A kokultúrában képzödö presvascularis struktúrákat Olympus Cell-R fluoreszcens mikroszkóppal 4x-es UplanSApo objektívvel lefényképeztük. Az ábrán reprezentativ képek láthatóak. Mérce $=500 \mu \mathrm{M}$

Ennek alapján az MSC klónokat H5V/MSC kokultúra rendszerben vizsgáltuk annak eldöntésére, hogy az MSC klonális szinten is rendelkezik-e proangiogén tulajdonsággal. Önmagában sem a H5V, sem az MSC klónok nem képeztek prevascularis struktúrákat. Kokultúra rendszerben viszont mindegyik MSC klón elősegítette a 
prevascularis struktúrák kialakulását (11. ábra), és a képződő struktúrák hossza hasonló volt a különböző MSC klónt tartalmazó kokultúrákban (12. ábra).

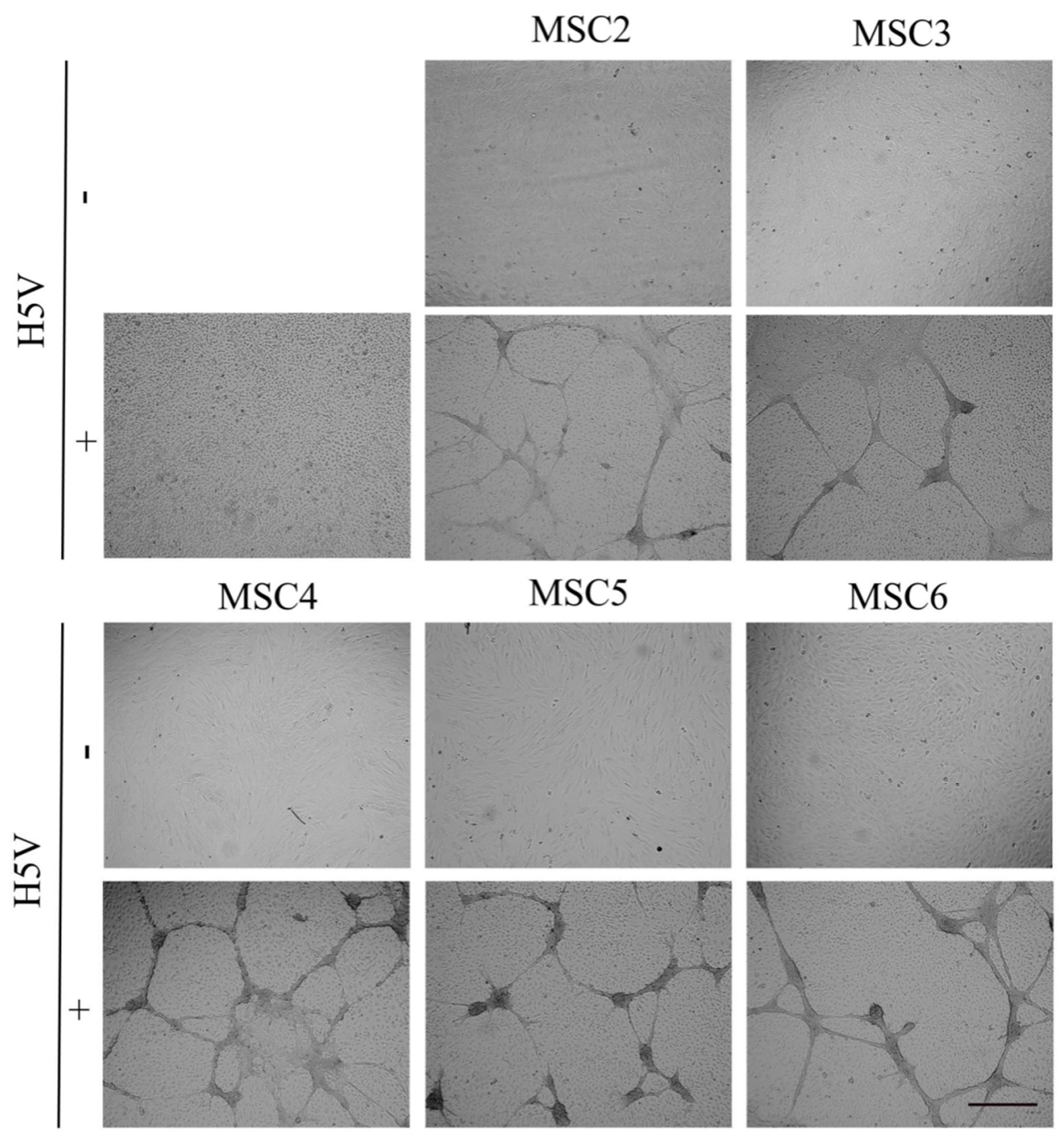

11. ábra. Az MSC klónok támogatják a prevascularis struktúrák képződését. A 3 napos kokultúrákban $\left(2 \times 10^{4} \mathrm{MSC}\right.$ és $\left.2 \times 10^{4} \mathrm{H} 5 \mathrm{~V}\right)$ képzödö presvascularis struktúrákat 5 random módon kiválasztott nem átfedö látómezöben fényképeztük (lásd 10. ábra). Mérce $=500 \mu \mathrm{M}$ 


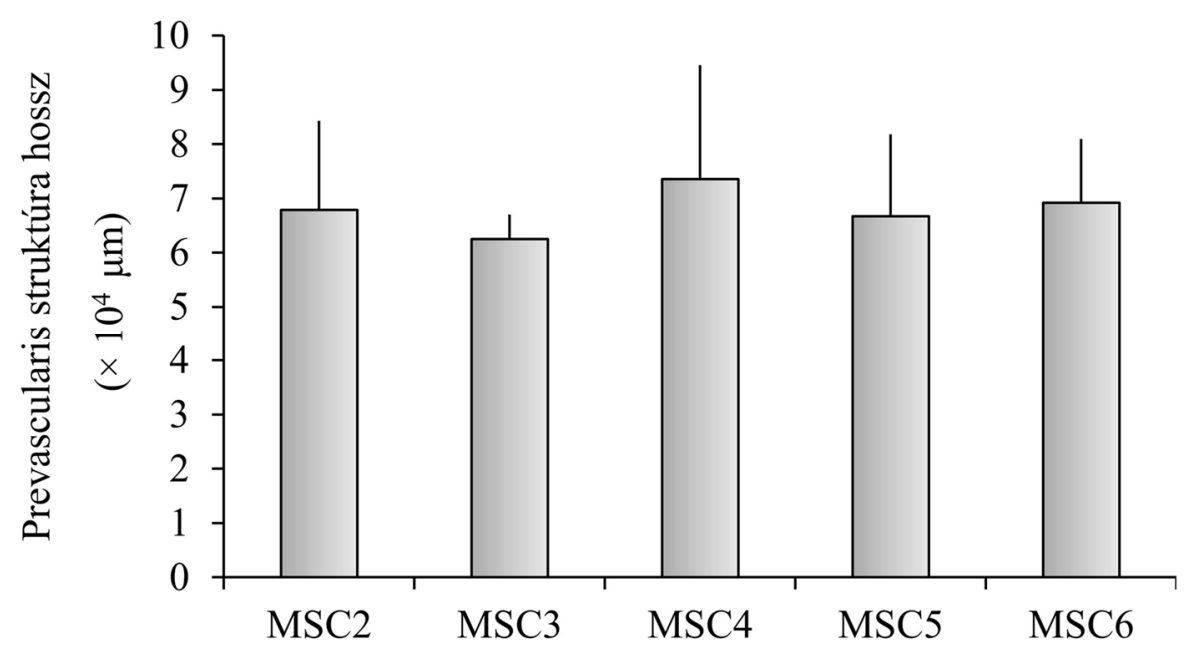

12. ábra. Az MSC klón/H5V kokultúrában képzödö presvascularis struktúrák hossza hasonló. Az MSC/H5V kokultúra 3. napján készitett 5 random módon kiválasztott, nem átfedö látómezöről készitett fotón CellR imaging szoftver segitségével megmértük a struktúrák hosszát. Az ábrán a 3 független kísérletben mért összstruktúrahossz átlagát jelenitettük meg (+SD).

Az MSC klónok proangiogén faktorokat kódoló génjeinek kifejeződését qRT-PCRrel vizsgáltuk és megállapítottuk, hogy az egyes gének expresszióját összevetve a klónokban az Angpt1, Vegfa és Lgals1 gének mRNS kifejeződése hasonló volt (13/AC. ábra). Az utóbbi faktor, a Gal-1 expresszióját fehérje szinten is analizáltuk. A 13/D és E ábra mutatja, hogy az egyes klónokban a Gal-1 szint hasonló. 
A

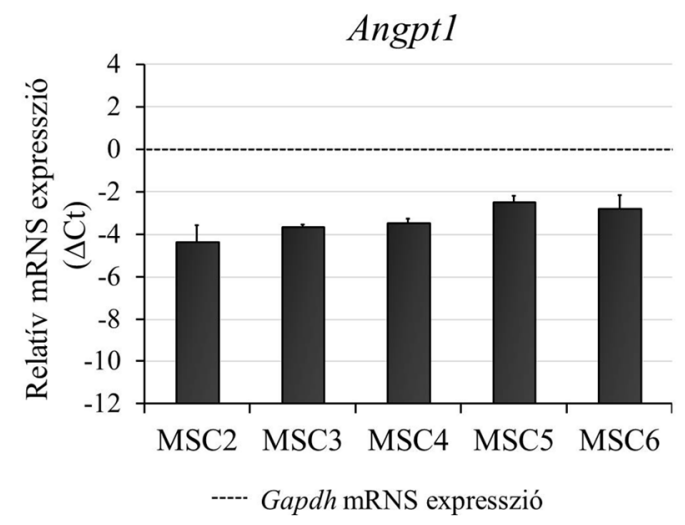

C

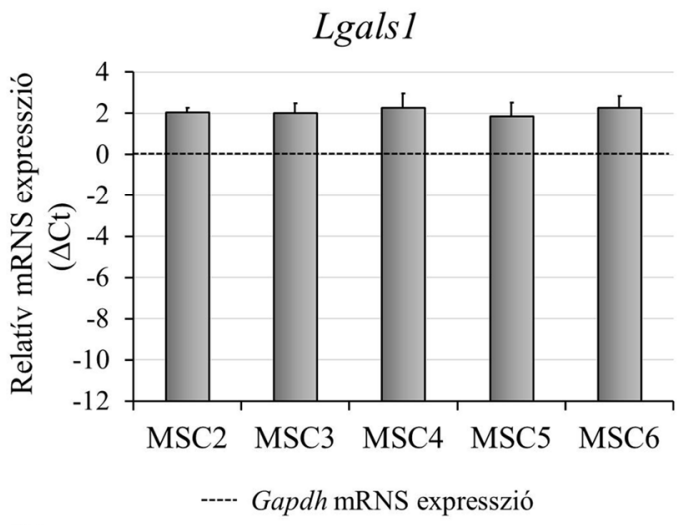

E

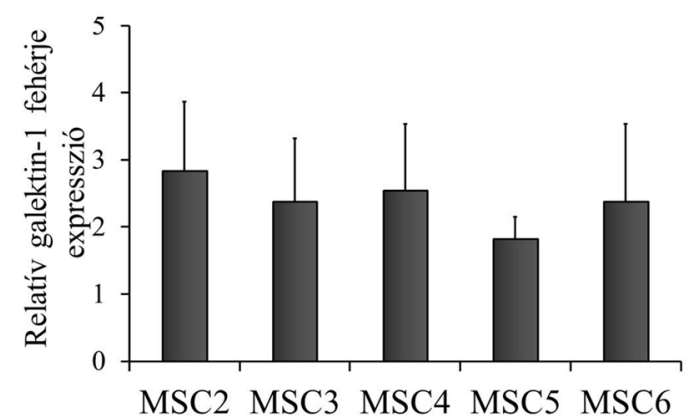

B

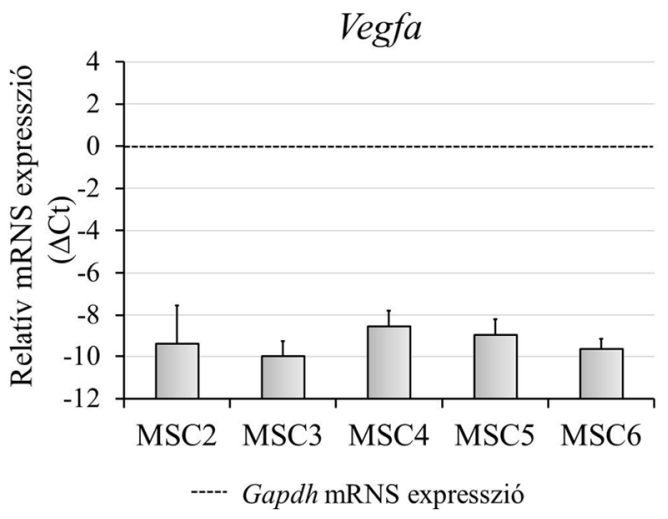

D

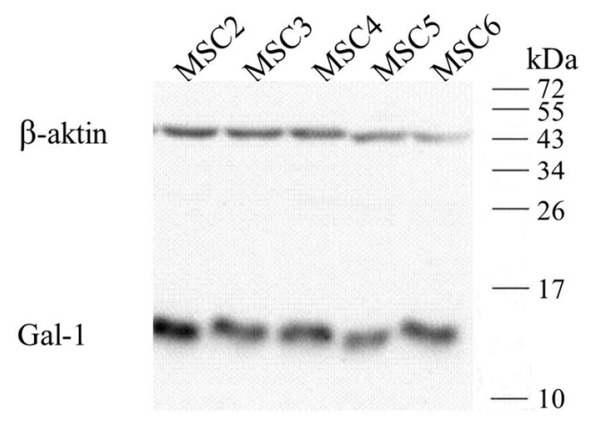

13. ábra. A vizsgált proangiogén faktorokat kódoló gének expressziója hasonló az egyes MSC klónokban. A.)-C.) A vizsgált gének expresszióját qRT-PCR segitségével vizsgáltuk. Az egyes gének kifejezödését (GOI) a Gapdh gén kifejezödéséhez viszonyitottuk a következö módon: $\Delta \mathrm{Ct}=\mathrm{Ct}_{\text {Gapdh }}-\mathrm{Ct}_{G O I .}$. A.) Angpt1, B.) Vegfa, C.) Lgals1. A $\Delta$ Ct értékek 3 független kisérlet átlagai (+SD). D.) Gal-1 fehérje expresszióját Western blottal analizáltuk. A reakció során a Gal-1-et nyúl anti-Gal-1 és HRP-konjugált anti-nyúl ellenanyaggal jelöltük, és Amersham ${ }^{\mathrm{TM}}$ ECL Prime reagenssel elöhivtuk. E.) A Gal-1 mennyiségek összehasonlitását a Western blot denzitometrálásával végeztük. A felvételen a detektált sávok denzitását VisionWorks ${ }^{\mathbb{B}}$ LS Image Acquisition and Analysis szoftverrel analizáltuk. A grafikonon 2 független kisérlet eredményének az átlaga $(+S D)$ szerepel. 


\section{2. Immunszuppresszív aktivitás és immunszuppresszív faktorok; T-sejt osztódás}

gátlása in vitro

V.2.a. Az MSC-k in vitro T-sejt osztódást gátló hatása

A klónozatlan, heterogén MSC kultúra hatását a ConA-val aktivált T-sejtek osztódására T-sejt/MSC kokultúrás rendszerben vizsgáltuk eltérö MSC-T-sejt arányoknál ( $1: 160 ; 1: 80 ; 1: 40 ; 1: 20$ és $1: 10)$. Az MSC-k $1: 160$ és $1: 80$ MSC/T-sejt arányban nem szignifikánsan, míg $1: 40,1: 20$ és $1: 10$ arányban szignifikánsan gátolták a T-sejtek proliferációját (14/A. ábra).

$\mathrm{Az}$ egér MSC immunszuppresszív hatásában a szakirodalom szerint a legjelentősebb faktorok az NO és a PGE2 $(91,114,115)$. Az NO és a PGE2 szerepét az MSC általi T-sejt osztódás gátlásában specifikus inhibítorokkal vizsgáltuk. Az NO, illetve a PGE2 gátlószerét, az L-NMMA-t, illetve indometacint az MSC-T-sejt kokultúrához adtuk. Mindkét gátlószer teljesen megszüntette a klónozatlan MSC kultúra gátló hatását a ConA-aktivált T-sejtek osztódására (14/B. és C. ábra). 
A

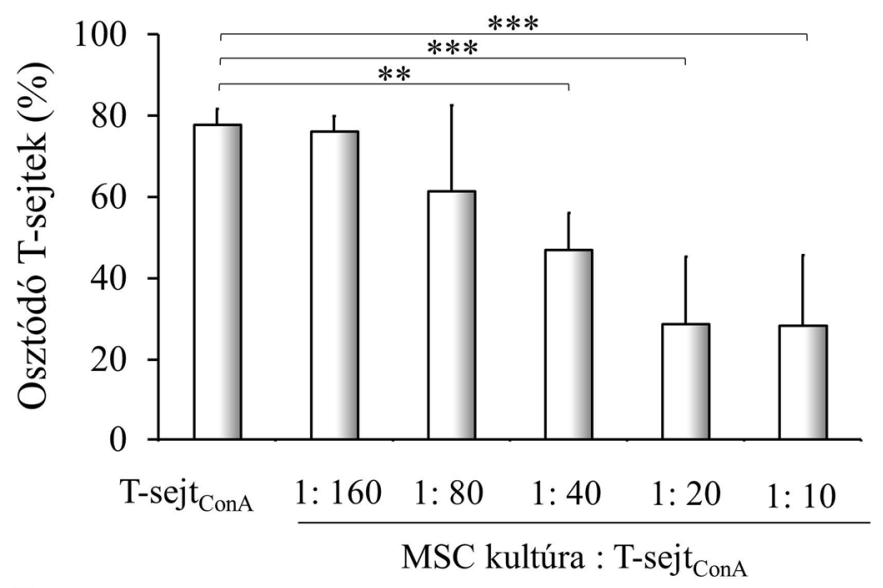

$\mathrm{B}$

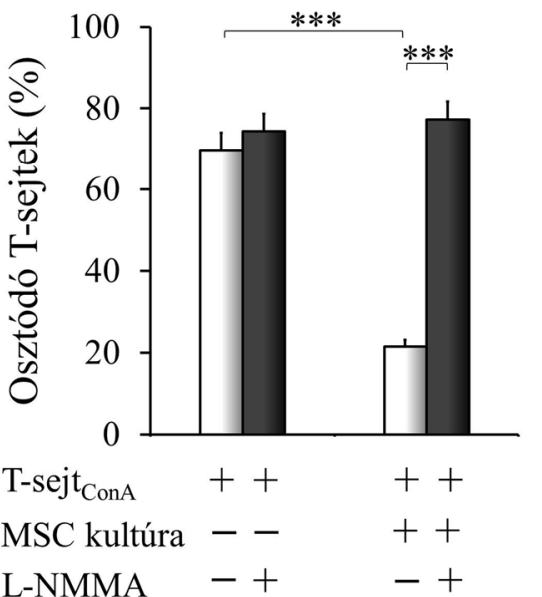

$\mathrm{C}$

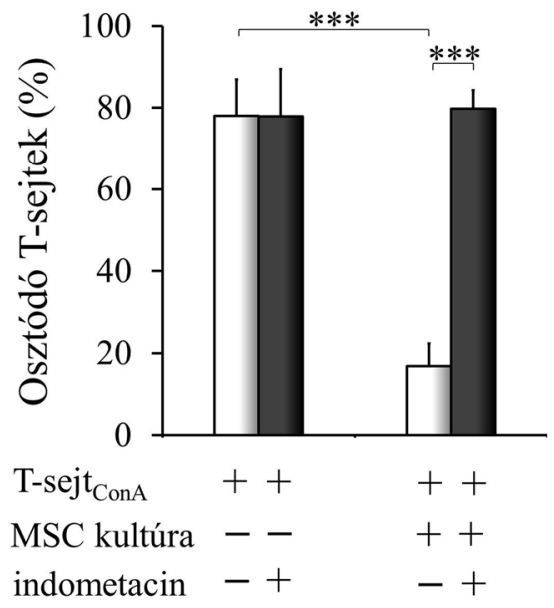

14. ábra. Az MSC kultúra T-sejt proliferáció gátló hatása és az NO, illetve a PGE2 szerepe ebben a folyamatban. A.) A CFSE-vel jelölt nyirokcsomó sejteket és az MSC-ket 1:160-1:10 arányban kokultúrába helyeztük. A T-sejtek proliferációját ConA-val stimuláltuk, és a kokultúra 3. napján a T-sejt proliferációt áramlási citométerrel mértük. B.) és C.) CFSE-vel jelölt nyirokcsomó sejteket MSC-vel 1:40 arányban tartottunk kokultúrában $50 \mu M$ L-NMMA (B), vagy $10 \mu M$ indometacin (C) jelenlétében, illetve inhibitorok nélkül. A T-sejt osztódást a kokultúra 3. napján áramlási citométerrel vizsgáltuk. A citofluorimetriás adatokat ModFit LT ${ }^{T M}$ szoftver segítségével értékeltük ki. Az A.) és C.) ábrák 2-2 független kisérlet eredményének az átlagát (+SD). jelenítik meg, a B.) kísérlet pedig 3 független, triplikátumokkal végzett kísérlet közül a reprezentatívat jeleníti meg.

Az MSC klónok in vitro immunszuppresszív képességének vizsgálatára is az MSCT-sejt kokultúrás rendszert alkalmaztuk. Az MSC klónok közötti különbségek előzetes kísérletek alapján az 1:40 arányú MSC-T-sejt kokultúrában jelentek meg, így a további kísérletekhez ezt az arányt választottuk. Mindegyik MSC klón szignifikánsan $(\mathrm{p}<0,001)$ 
gátolta a ConA-aktivált T-sejtek proliferációját, ugyanis az MSC klónok jelenlétében az osztódó T-sejtek aránya az MSC nélküli kontrollhoz képest alacsonyabb volt (15/B. ábra). Az MSC2, MSC4 és MSC5 klón erőteljesen gátolta a ConA-aktivált T-sejtek proliferációját, míg az MSC3 és MSC6 gyenge gátló hatást fejtett ki (15/A-B. ábra). Az MSC klónok között gátlóképesség alapján a következő sorrendet állíthatjuk fel: MSC2 $\geq$ MSC5 > MSC4 > MSC3 >> MSC6.

A

ConA-aktivált T-sejt proliferáció

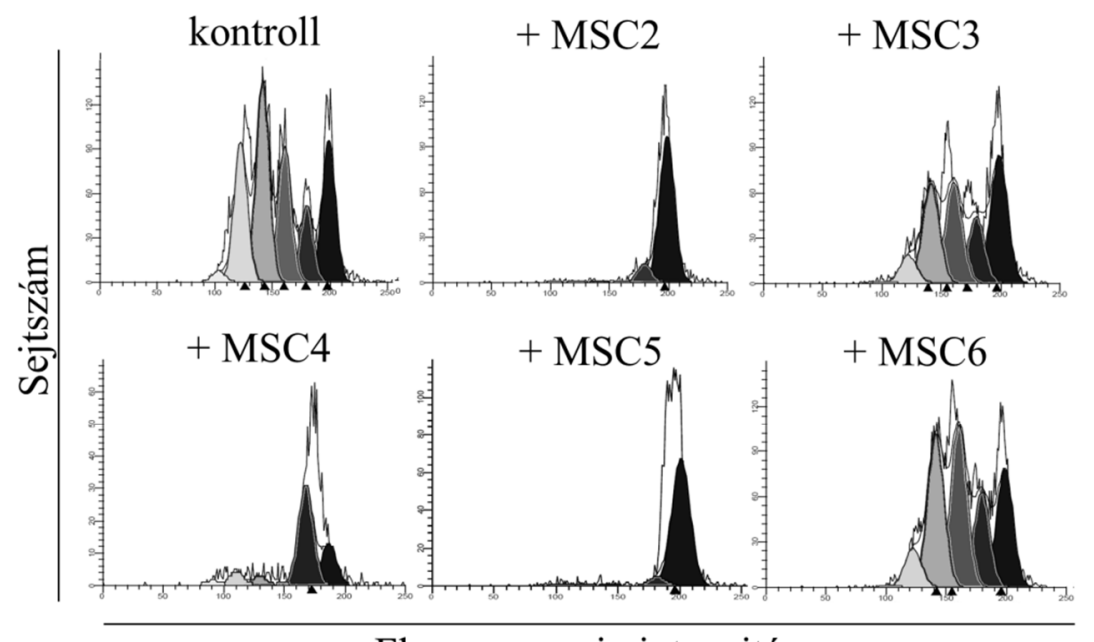

Fluoreszcencia intenzitás

B

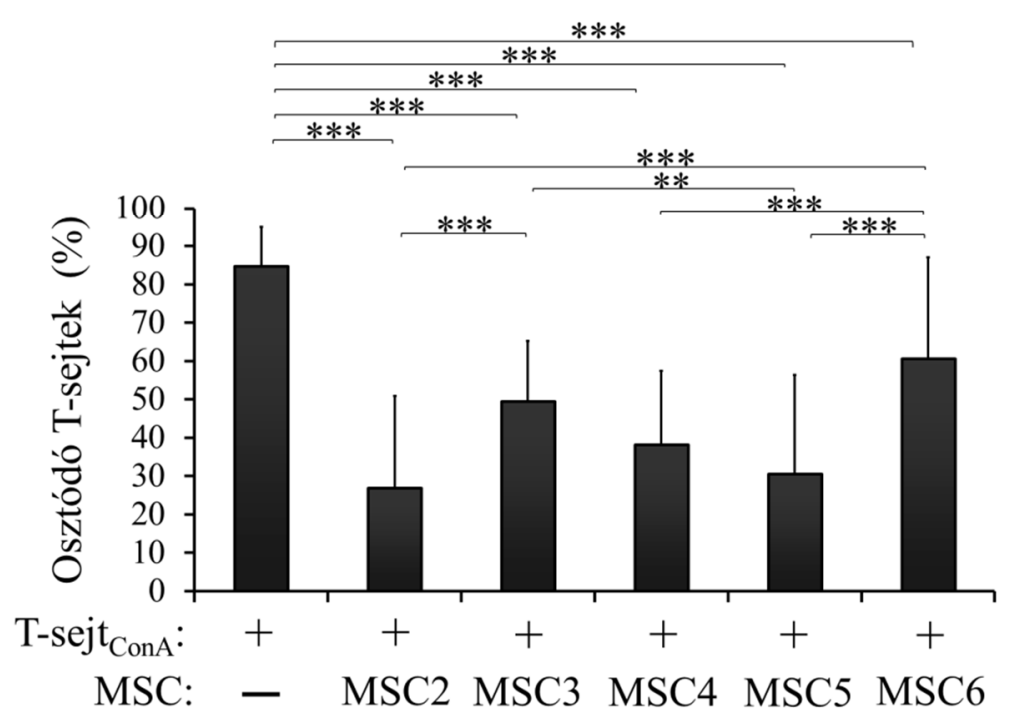

15. ábra. Az MSC klónok gátlása a ConA-aktivált T-sejtek proliferációjára. A kokultúrás kisérlet a 14. ábrán leirtak szerint történt. Az A.) ábrán az MSC2-6-T-sejt kokultúrák reprezentatív citofluorimetriás profilja látható. A citofluorimetriás adatokat ModFit $L T^{T M}$ szoftver segitségével értékeltük ki. A B.) ábra 5 független, triplikátumokkal elvégzett kisérlet eredményét mutatja. 


\section{V.2.b. Az immunszuppresszív faktorok génkifejeződése az MSC klónokban}

Annak eldöntésére, hogy az MSC klónok közötti különbség a T-sejt proliferáció gátlásában abból adódik, hogy a klónok immunmoduláló génjeinek kifejeződése eltérő, qRT-PCR-rel megállapítottuk az NO és a PGE2 szintézisért felelős Nos2, Ptgs2, illetve a triptofán hiányos környezetet kialakító enzimet kódoló gén, az Idol relatív mRNS szintjét. A Nos2 alap állapotú kifejeződése tükrözte az MSC klónok T-sejt proliferáció gátló képességét. Az MSC2 és MSC5 klónok esetén mintegy 3 nagyságrenddel (a relatív mRNS különbség: 3338, illetve 1991), az MSC4 klónban pedig 2 nagyságrenddel (a relatív mRNS különbség 127) magasabban fejeződött ki a Nos2, mint az MSC3-ban. Az MSC6-ban a Nos2 mRNS expresszió egyáltalán nem volt detektálható (16/A. ábra).

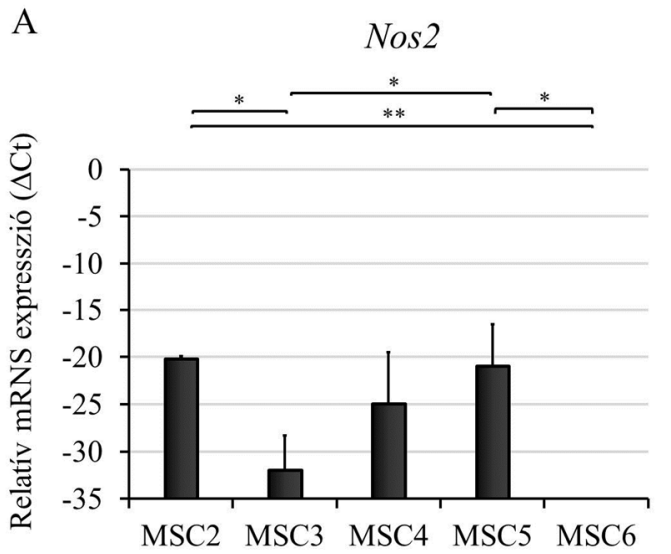

B $\quad \operatorname{Ptg} 2$

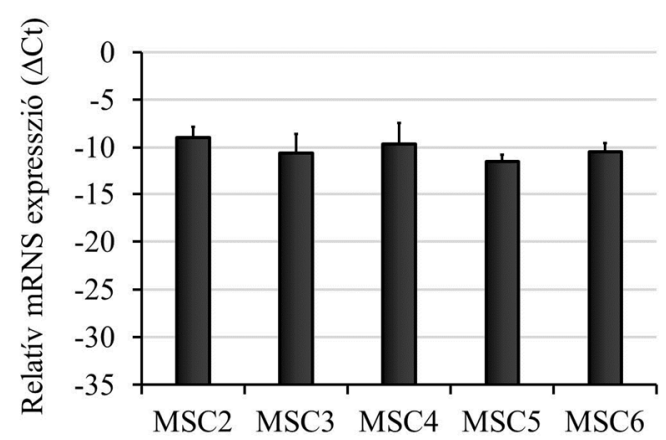

16. ábra. Az MSC klónok immunszuppresszív faktorait kódoló gének kifejezödése. Az MSC-k kiültetését követöen 24 óra múlva RNS-t izoláltunk. A Nos2 (A) és Ptgs2 (B) gének kifejezödését qRT-PCR során a Gapdh háztartási gén kifejezödéséhez viszonyitottuk. Az ábrán 2 független kísérlet átlagát jelenitettük meg (+SEM).

A Ptgs2 alapállapotban minden klónban magasabban fejeződött ki, mint a Nos2, és a Ptgs2 mRNS expresszióban nem volt szignifikáns különbség a klónok között (16/B. ábra). Az Idol mRNS alapállapotban qRT-PCR-rel nem volt kimutatható egyik MSC klónban sem (21/C. ábra).

\section{V.2.c. Az in vitro T-sejt osztódás gátlásának hatásmechanizmusa}

A hatásmechanizmus vizsgálatához a legerősebb és leggyengébb T-sejt proliferáció gátlást mutató MSC2 és MSC6 klónt választottuk. Az immunszuppresszív faktorok, az 
NO, a PGE2 és az IDO1 szerepének tisztázására az MSC-T-sejt kokultúrákban specifikus inhibítorokat, L-NMMA-t, indometacint és 1-MT-t alkalmaztunk. Az L-NMMA teljesen, míg az indometacin részlegesen fordította vissza az MSC2 T-sejt proliferáció gátló hatását (17/A. ábra). Ezzel szemben a gátlószerek jelenléte nem befolyásolta az MSC6 gátló hatását (17/A. ábra). Az 1-MT, nem meglepő módon hatástalan volt a két MSC klón aktivitására (17/B. ábra), hiszen az IDO kifejeződése nem mutatható ki a klónokban (21/C. ábra).

A

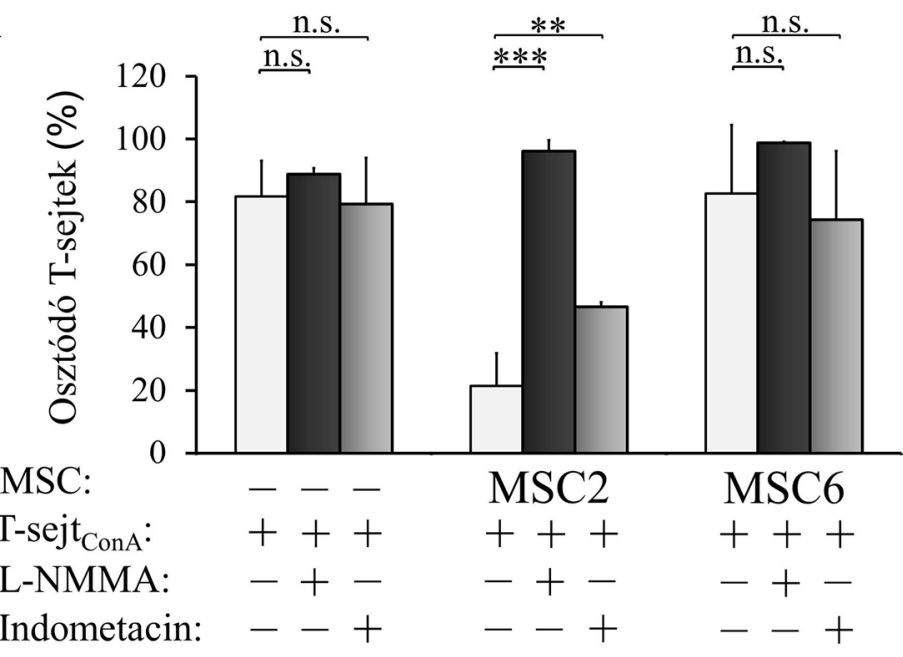

B

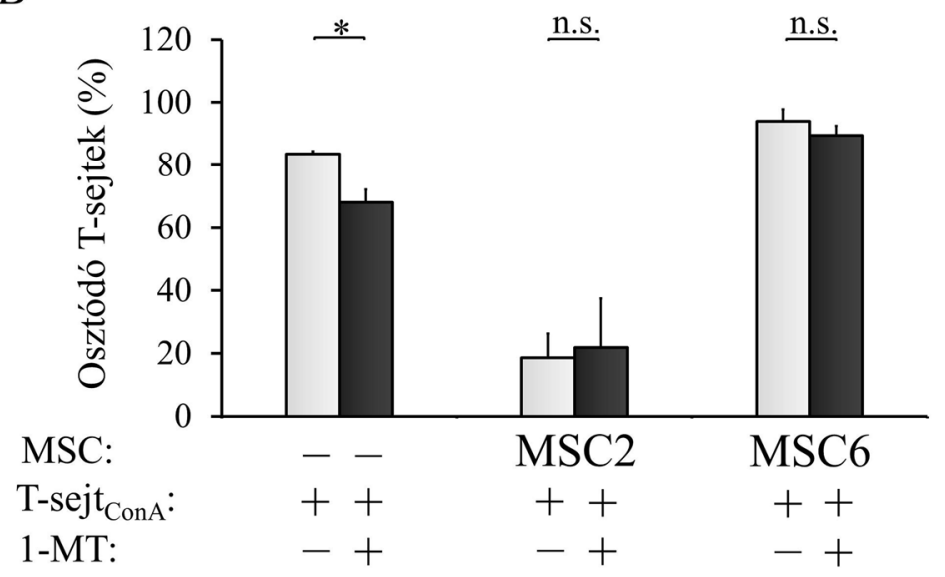

17. ábra. Az NO, a PGE2 és az IDO1 szerepe az MSC2 és MSC6 klón T-sejt proliferáció gátló hatásában. A 14. ábrán leirtak szerint létesitett kokultúrához $1 \mathrm{mML}$-NMMA-t (A), $10 \mu M$ indometacint (A), illetve $1 \mathrm{mM}$ 1-MT-t (B) adtunk vagy gátlószer nélkül inkubáltuk. A T-sejtek proliferációját áramlási citométerrel mértük 72 órás kokultúrában és az adatokat a ModFit LT ${ }^{T M}$ szoftver segitségével értékeltük ki. Az A.) és B.) ábra egy triplikátumokkal végzett reprezentatív kísérlet eredményét mutatja. 


\section{V.3. Gyulladásos faktorok hatása az MSC-k funkcióira}

\section{V.3.a. Differenciáció}

A gyulladásos környezet befolyásolja az MSC-k differenciálódását (129-134,136). Kérdésünk az volt, hogy vajon a különböző differenciálódási készséget mutató, egy sejtből kialakuló MSC klónok hasonló módon változnak-e gyulladásos mikrokörnyezetben. Az MSC2 és MSC6 klónokat IFN- $\gamma$-val és TNF- $\alpha$-val kezeltük és vizsgáltuk csont irányú differenciálódásukat. A citokinavatás megszüntette a stimulálás nélkül jól differenciálódó MSC2 klón csont irányú differenciációját, míg nem befolyásolta a stimulálás nélkül sem differenciálódó MSC6 klónt (18/A. ábra).

A fenti eredményekkel összhangban a 24 órás IFN- $\gamma$ és TNF- $\alpha$ kezelés csökkentette az MSC2 és MSC6 klón csont irányú differenciálódását szabályozó és jelző markergének, a Runx2, Bglap és Spp1 kifejeződését (18/B. ábra). 
A

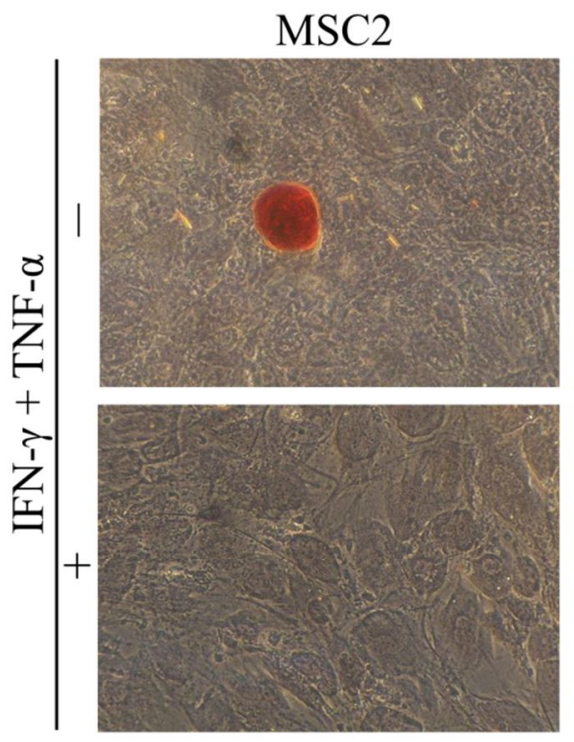

$\mathrm{B}$
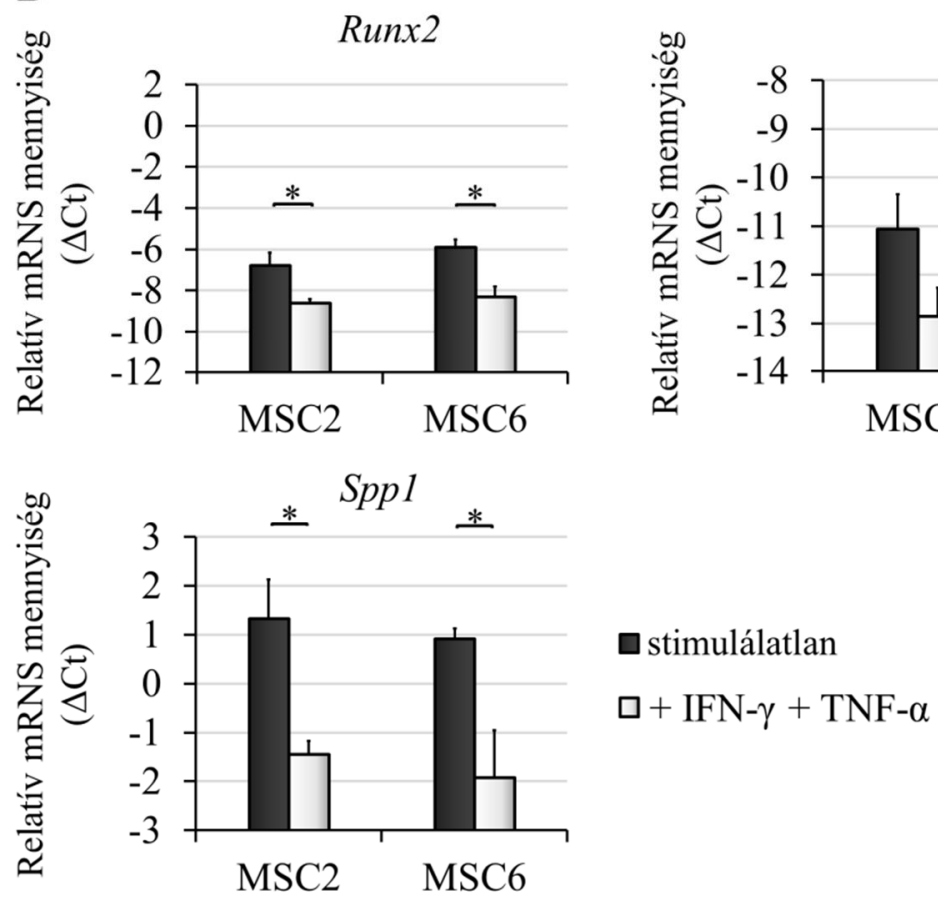

18. ábra. A citokinavatás hatása az MSC2 és MSC6 in vitro csontképzö sejt irányú differenciálódására és a differenciációs markergének kifejezödésére. A.) A $100 \mathrm{ng} / \mathrm{mL}$ IFN- $\gamma$-val és $50 \mathrm{ng} / \mathrm{mL} T N F$ - $\alpha$-val elökezelt MSC2 és MSC6 kultúrákat 14 napra csont differenciáltató médiumba helyeztük. A csontosodási gócokban felhalmozódó kálcium festése Alisarin Red S-sel történt. A csontképzö sejt differenciációról CKX41 mikroszkóphoz kapcsolt Olympus Camedia C-5060 kamerával készitettünk fényképeket. Mérce $=50 \mu M$. B.) A nem stimulált (fekete oszlopok) vagy citokinekkel stimulált (szürke oszlopok) MSC2 és MSC6 klónokból izolált RNS-böl qRT-PCR-rel vizsgáltuk a Runx2, Bglap és Sppl gének kifejezödését, melyeket a Gapdh háztartási gén kifejezödéséhez viszonyitottuk. A grafikon 2 független kísérlet eredményét (+SEM) jeleniti meg. 


\section{V.3.b. Proangiogén hatás}

A neoangiogenezis fontos lépése a szövetregenerációnak. A szövetek sérülése sok esetben a krónikus gyulladásoknak tudható be, ezért a gyulladásos környezet hatása az MSC által támogatott érképzésre fontos szempontja volt a vizsgálatunknak. A 19. ábra mutatja, hogy a citokinek, IFN- $\gamma$ és TNF- $\alpha$ jelenlétében az MSC klónok H5V endotélsejtekkel együtt tenyésztve nem, vagy csak nagyon csekély mértékben képeztek prevascularis struktúrákat a citokin nélküli MSC-H5V kokultúrákhoz képest (19/A és B. ábra).

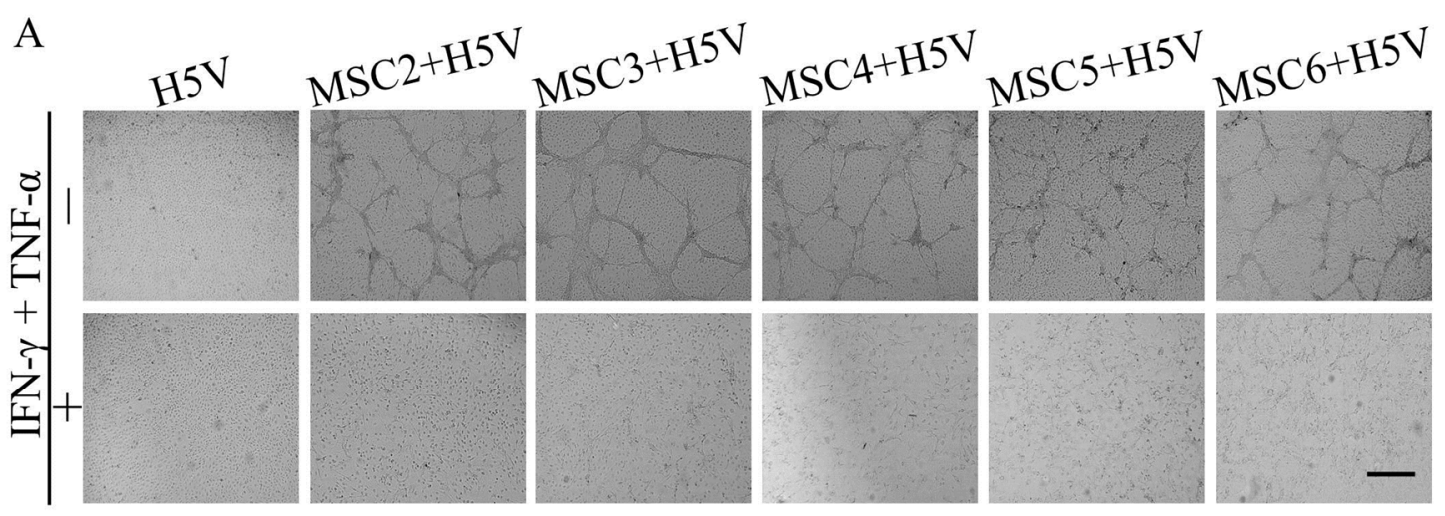

$\mathrm{B}$

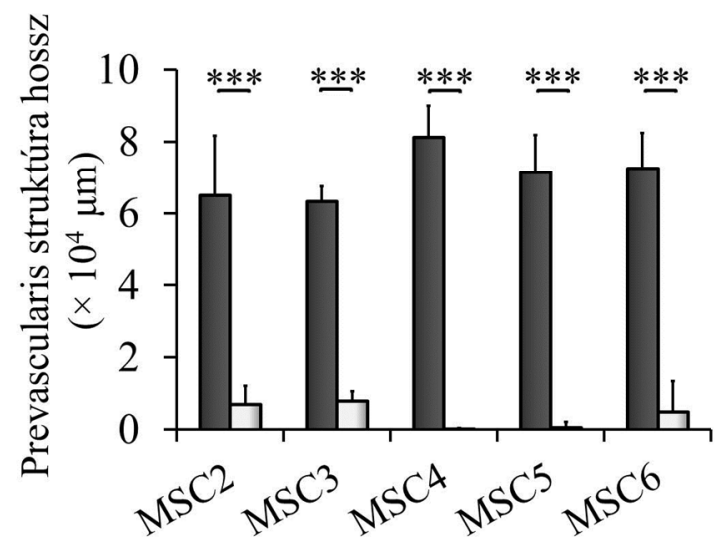

19. ábra. Gyulladásos citokinek hatása az MSC-k proangiogén funkciójára. A.) MSC-t $\left(2 \times 10^{4}\right.$ sejt $)$ és H5V-t $\left(2 \times 10^{4}\right.$ sejt $) 3$ napig együtt-tenyésztettünk 24-lyukú lemezen $20 \mathrm{ng} / \mathrm{mL} \quad I F N-\gamma$ és $10 \mathrm{ng} / \mathrm{mL}$ TNF- $\alpha$ hozzáadásával vagy anélkül (kontroll). A kokultúrában képzödö presvascularis struktúrákat 5 random módon kiválasztott nem átfedö látómezöben Olympus Cell-R fluoreszcens mikroszkóppal, 4x-es UplanSApo objektívvel fényképeztük. Az ábrán reprezentativ képek láthatóak. Mérce $=500 \mu M$. B.) CellR imaging szoftver segitségével mértük a struktúrák hosszát. Az ábrán az 5 látómezöben mért összesitett struktúrahosszat jelenitettük meg, mely 3 független kísérlet eredményének az átlaga $(+S D)$. 


\section{V.3.c. T-sejt proliferáció gátlás in vitro modellrendszerben}

Az MSC-k a sejttranszplantációk során sok esetben krónikus gyulladásos környezetbe kerülnek, melyben a gyulladásos citokinek koncentrációja magas. A következőkben azt vizsgáltuk, hogy a gyulladásos mikrokörnyezet hogyan befolyásolja az MSC-k T-sejt osztódást gátló tulajdonságát. A krónikus gyulladás fenntartásában a Th1sejtek és a makrofágok által termelt IFN- $\gamma$-nak és TNF- $\alpha$-nak van szerepe. A krónikus gyulladásos mikrokörnyezet modellezésére T-sejteket aktiváltunk anti-CD3/CD28 ellenanyaggal. A T-sejt receptoron keresztül ilyen módon aktivált T-sejtek felülúszójában az IFN- $\gamma$ és a TNF- $\alpha$ mennyisége volt a legmagasabb (20/A. ábra). Ezt a felülúszót adtuk a klónozatlan, heterogén MSC kultúrához, és mértük az MSC-ben az immunmoduláló citokinek vagy az előállításukért felelős enzimeket kódoló gének (Nos2, Ptgs2 és Ido1) expressziós változását. Az aktivált T-sejtek felülúszója magasabb szintre növelte a stimulálatlan MSC kultúrában alacsonyan kifejeződő Nos2 mRNS szintjét (relatív mRNS változás: 27,66), indukálta az eddig nem kifejeződő Ido1 expressziót, és a Ptgs 2 mRNS szintjében pedig nem okozott változást (20/B.ábra). A T-sejt felülúszóban aktiválás hatására nagy mennyiségben megjelenő IFN- $\gamma$ és TNF- $\alpha$ szerepét tisztított citokinekkel vizsgáltuk tovább. A Nos2 mRNS kifejeződését a két citokin külön-külön is fokozta $\left(2^{\Delta \Delta \mathrm{CtIFN}-\gamma}=7,36 ; 2^{\triangle \Delta \mathrm{CtTNF}-\alpha}=18,64\right)$, ám a két citokin együtt sokkal erőteljesebben $\left(2^{\Delta \Delta \mathrm{CtIFN}-\gamma \mathrm{TNF}-\alpha \gamma}=4705\right)$ növelte az MSC kultúra Nos2 mRNS kifejeződését (20/C. ábra). A Ptgs 2 mRNS kifejeződésére az IFN- $\gamma$ nem volt hatással $\left(2^{\Delta \Delta \mathrm{CtIFN}-\gamma}=1,12\right)$, a TNF- $\alpha$ viszont növelte $\left(2^{\Delta \Delta \mathrm{CtTNF}-\alpha}=6,1\right)(20 / \mathrm{C}$. ábra). Az Idol mRNS kifejeződést az IFN- $\gamma$ és a két citokin kombinációja jelentősen növelte, míg a TNF- $\alpha$ önmagában nem volt rá hatással (20/C. ábra). Ezeket az eredményeket figyelembe véve az MSC klónok kezelésére a két citokint együttesen használtuk.

Annak vizsgálatára, hogy az IFN- $\gamma$ és TNF- $\alpha$ kezelés hatására megemelkedett Nos 2 mRNS szint befolyásolja-e a klónozatlan, heterogén MSC kultúra T-sejt proliferáció gátló képességét, az aktivált T-sejt proliferáció mértékét az IFN- $\gamma$-val és TNF- $\alpha$-val előkezelt MSC-k jelenlétében vizsgáltuk. A citokinnel előkezelt MSC kultúra szignifikánsan $(\mathrm{p}<0,01)$ jobban gátolta a ConA-aktivált T-sejtek osztódását (20/D. ábra). 
A

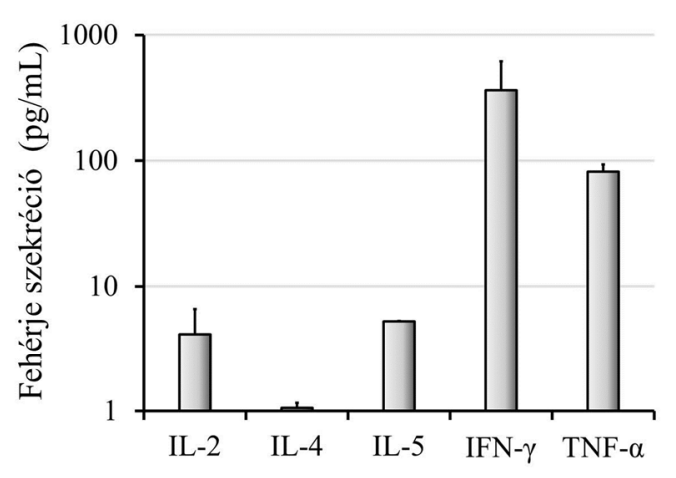

$\mathrm{C}$

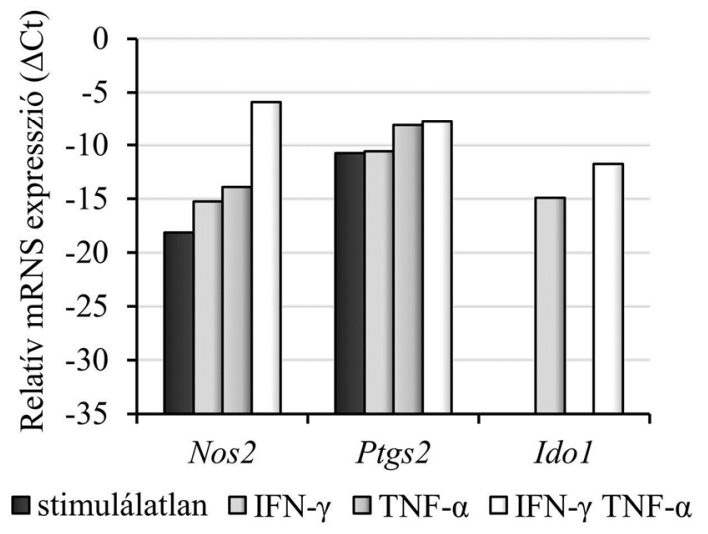

B

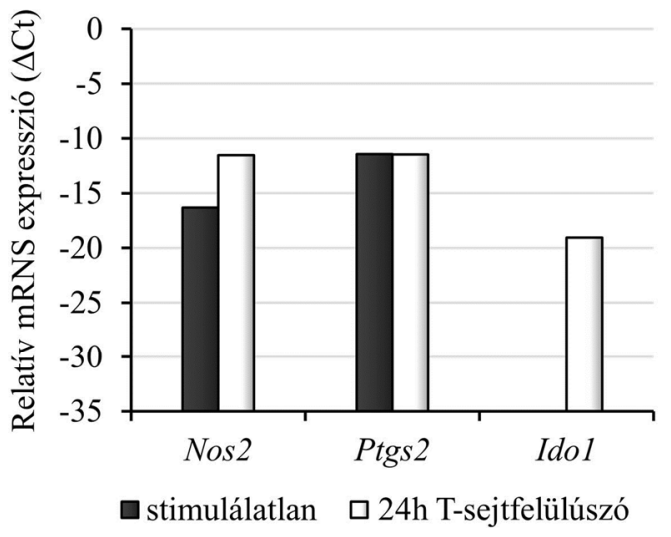

$\mathrm{D}$

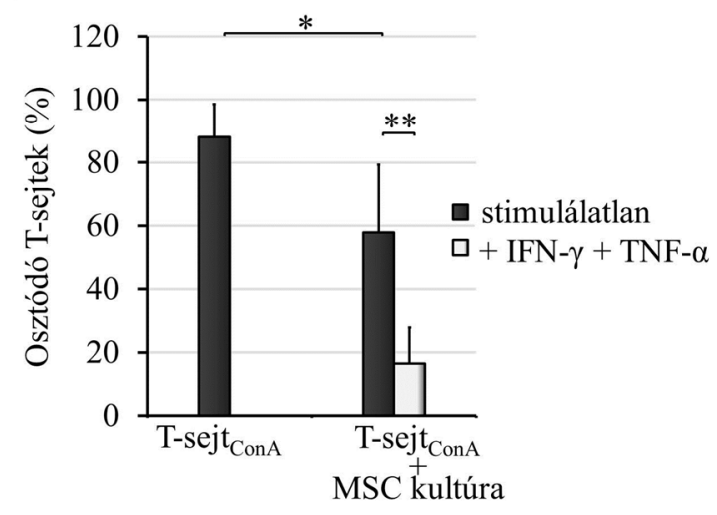

20. ábra. Gyulladásos citokinek hatása az MSC kultúra immunszuppresszív faktorainak termelödéséért felelös gének kifejezödésére és az MSC-k in vitro T-sejt proliferáció gátlására. A.) Az izolált T-sejteket 72 órán át anti-CD3/CD28 ellenanyaggal aktiváltuk,

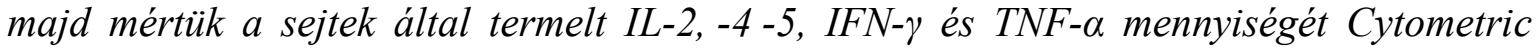
Bead Array és Mouse Th1/Th2 Cytokine kit segitségével. B.) Az MSC kultúrán a második napon a médium felét 72 órán át anti-CD3/CD28-cal aktivált T-sejtek felülúszójára cseréltük, ezt követöen 24 órával RNS-t izoláltunk, és qRT-PCR-rel mértük a jelölt gének kifejezödését. A génexpressziót a Gapdh háztartási gén kifejezödéséhez viszonyitottuk. C.)

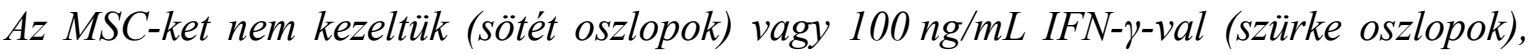
$50 \mathrm{ng} / \mathrm{mL} T N F-\alpha$-val (szürke oszlopok), vagy a két citokinnel együttesen 24 óráig kezeltük (világos oszlopok), majd RNS izolás után qRT-PCR-rel mértük a jelölt gének expresszióját. D.) Az MSC-ket nem kezeltük (sötét oszlopok) vagy $100 \mathrm{ng} / \mathrm{mL} I F N$ - $\gamma$-val és $50 \mathrm{ng} / \mathrm{mL}$ TNF- $\alpha$-val együtt (világos oszlopok) 24 óráig stimuláltuk a kokultúrába helyezés elött. A Tsejt osztódást az MSC/T-sejt kokultúrában a 13. ábrán leirtak szerint mértük. A D.) ábra 2 független, triplikátumokkal elvégzett kísérlet eredményét $(+S D)$ mutatja.

Az MSC klónok gyulladásos citokinekkel (IFN- $\gamma$ és TNF- $\alpha$ ) történő kezelése mindegyik klónban nagy mértékben megnövelte a Nos 2 (relatív mRNS változás $8 \times 10^{4}$ - 
$\left.1,08 \times 10^{8}\right)(21 /$ A. ábra) és Idol (21/C. ábra) expresszióját, míg a Ptgs2 (21/B. ábra) kifejeződésére kisebb hatással volt (átlagos mRNS változás 9,2). Az MSC3 és MSC6 klónban alacsonyan vagy nem kifejeződő Nos2 mRNS (21/A. ábra) a citokinkezelés hatására a többi klónhoz hasonlóan magas szintre emelkedett (21/A. ábra) kiegyenlítve a stimulálatlan klónok között tapasztalt különbségeket.

A

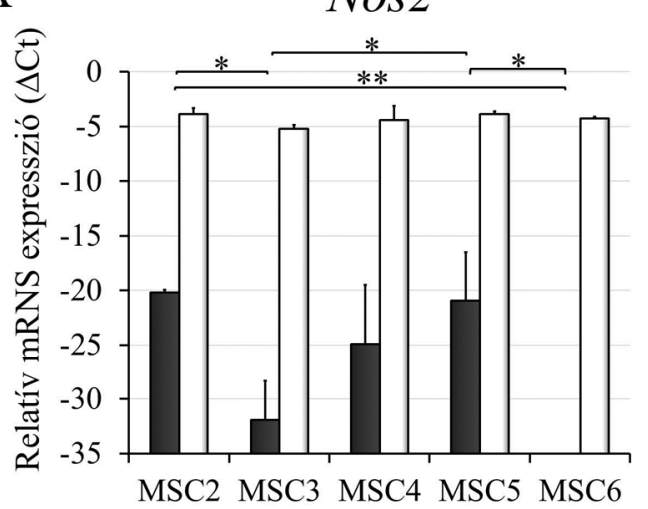

C

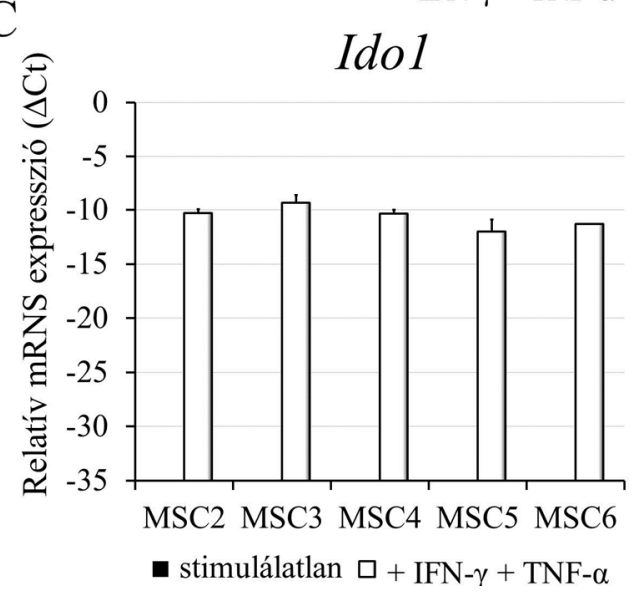

$\mathrm{B}$

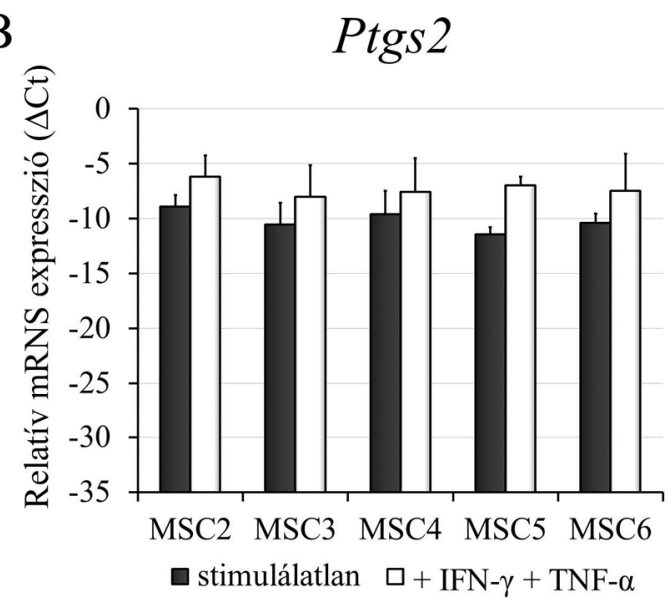

21. ábra. Gyulladáskeltö citokinek hatása az MSC klónok immunszuppresszív faktorait kódoló gének kifejezödésére. Az MSC-ket stimulálatlanul hagytuk (fekete oszlopok), vagy 24 óráig $100 \mathrm{ng} / \mathrm{mL} I F N$ - $\gamma$-val és $50 \mathrm{ng} / \mathrm{mL} T N F$ - $\alpha$-val kezeltük (fehér oszlopok), majd a sejtekböl RNS-t tisztitottunk. A Nos2 (A), a Ptgs2 (B) és az Ido1 (C) gének kifejezödését qRT-PCR-rel vizsgáltuk. A vizsgált gén expressziójának mértékét a Gapdh háztartási gén kifejezödéséhez viszonyitottuk. Az ábrán 2 független kisérlet átlagát jelenitettük meg $(+S E M)$.

Az MSC klónok immunszupresszív faktorainak expresszió növekedése (21. ábra) összhangban volt a T-sejt proliferáció gátló hatásukban bekövetkező változásokkal. A gyulladáskeltő citokinekkel (IFN- $\gamma$ és TNF- $\alpha$ ) történő előkezelés fokozta az MSC klónok 
immunszuppresszív sajátságát (22/A. ábra). A T-sejt osztódást gátló hatás fokozódása a gyengén gátló klónoknál, az MSC3-nál és MSC6-nál érvényesült legjobban, míg a stimulálatlanul is erősen gátló klónok hatása (MSC4 és MSC5) csekély mértékben erősödött, és a legerősebben gátló klón (MSC2) gátló hatása nem változott (22/B. ábra).

A

ConA-aktivált T-sejt proliferáció

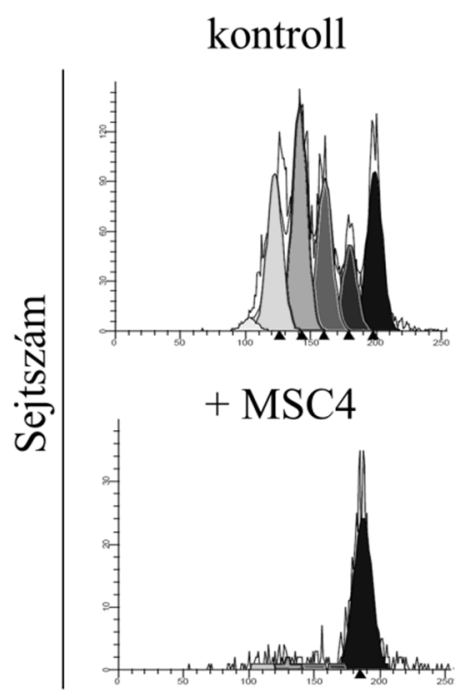

$+\operatorname{MSC} 2$

$+\mathrm{MSC} 3$
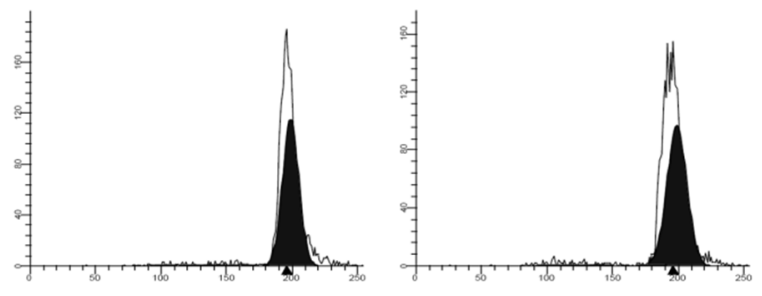

+ MSC5

+ MSC6
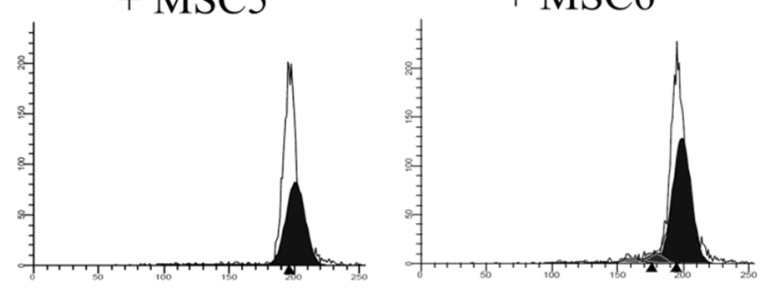

Fluoreszcencia intenzitás

B

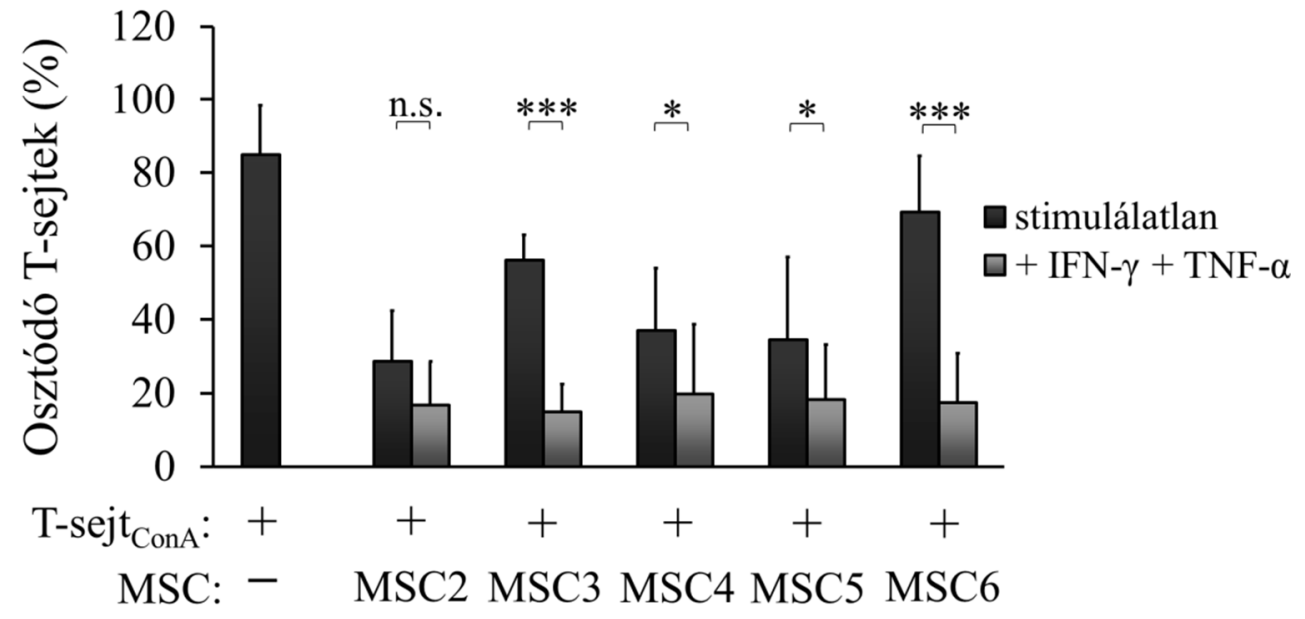

22. ábra. A IFN-y és TNF-a kezelés különbözö mértékben serkenti az MSC klónok Tsejtek proliferáció gátló hatását. A T-sejt proliferációs kokultúrás kísérlet a 14. ábra alatt leirtak szerint történt. A.) Az MSC-T-sejt kokultúrák reprezentativ citofluorimetriás profilja. B.) $A z$ A.) ábrán bemutatott citofluorimetriás adatokat 5 független, triplikátumokkal végzett kisérlet esetében ModFit $L T^{T M}$ szoftver segitségével értékeltük ki. 
Az előző kísérletek bizonyítják, hogy a gyulladásos citokinek jelenléte fokozza az MSC-k immunszuppresszív faktorainak expresszióját (21. ábra) és T-sejt proliferáció gátló hatását (22. ábra). A következőkben azt vizsgáltuk, hogy mely(ek) az(ok) az MSC-eredetü faktor(ok), melyek részt vesznek a T-sejt osztódás szabályozásában gyulladásos mikrokörnyezetben. Specifikus inhibítorokkal gátoltuk az NO (L-NMMA) és a PGE2 (indometacin) szintézisét és az IDO (1-MT) aktivitását az IFN- $\gamma$-val és TNF- $\alpha$-val stimulált legerőteljesebb MSC2 és leggyengébb gátlást mutató MSC6 klónban. Az L-NMMA teljes mértékben megszüntette mindkét citokinekkel kezelt klón T-sejt proliferáció gátlását (23/A. ábra), mely igazolja, hogy az NO az MSC klónok fó faktora a T-sejt proliferáció gátlásban. Ezzel szemben a PTGS2-gátló indometacin csak részben csökkentette a citokinekkel kezelt MSC6 osztódásgátló hatását, a citokinekkel kezelt MSC2 esetében pedig hatástalan volt (23/A. ábra). Az IDO1 inhibítor 1-MT nem befolyásolta sem az MSC2, sem az MSC6 gátló hatását a T-sejtek osztódására (23/B. ábra) annak ellenére, hogy a gyulladáskeltő citokinkezelés eröteljesen indukálta az MSC klónokban az Ido1 mRNS kifejeződését (21/C. ábra). 

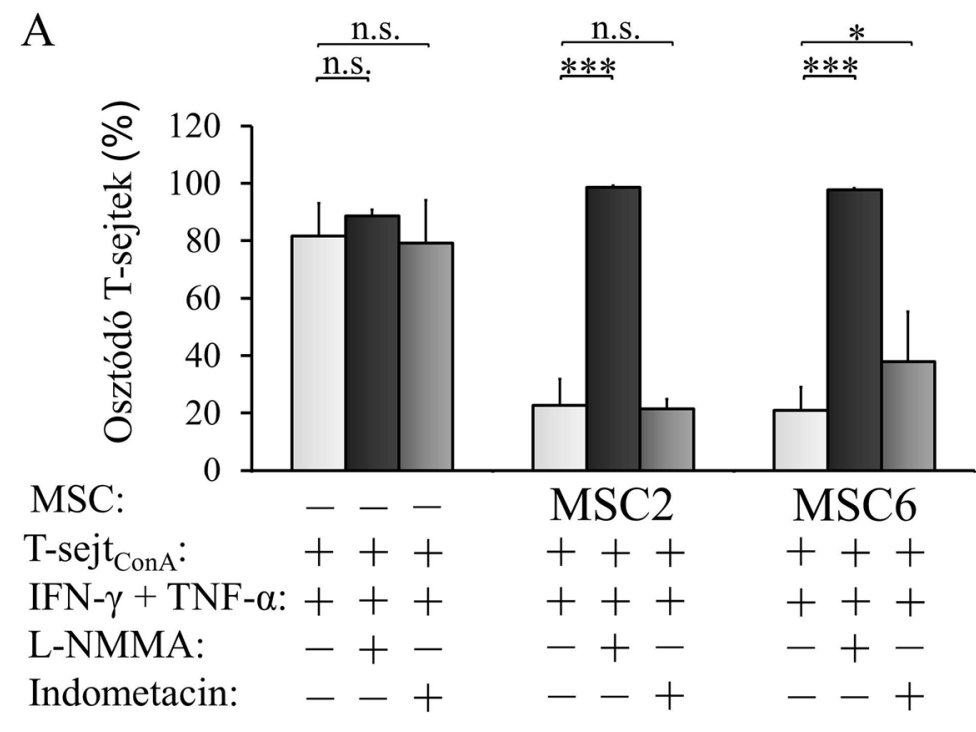

B

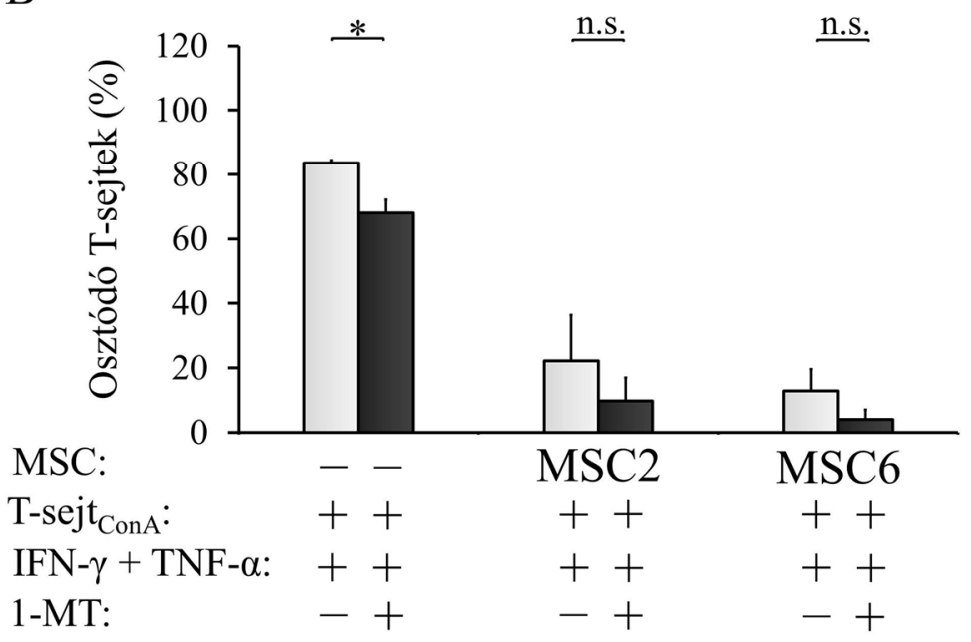

23. ábra. Az NO, a PGE2 és az IDO1 szerepe a gyulladáskeltó citokinekkel elökezelt MSC2 és MSC6 klón T-sejt proliferáció gátló hatásában. Az MSC-T-sejt kokultúrát a 14. ábránál leirt módon állitottuk össze A.) $1 \mathrm{mM} L$-NMMA, $10 \mu \mathrm{M}$ indometacin és B.) $1 \mathrm{mM}$ 1-MT jelenlétében vagy gátlószer nélkül. A T-sejtek proliferációját áramlási citométerrel mértük 72 órás kokultúrában, és az adatokat a ModFit $L T^{T M}$ szoftver segitségével értékeltük ki. Az A.) és B.) ábra egy triplikátumokkal elvégzett reprezentativ kisérlet eredményét $(+S D)$ mutatja.

\section{V.4. In vivo DTH egérmodell alkalmazása az MSC-k és MSC klónok gyulladáscsökkentő hatásának igazolására}

Az in vivo immunszuppresszív aktivitás vizsgálatához a csirke tojásfehérje, az ovalbumin által kiváltott késői típusú túlérzékenységi reakciót (DTH) választottuk. A kísérlet során ovalbumint oltottunk az egerek bőre alá és 4 nap után megismételve az oltást 
az egerek talppárnájába kiváltottuk a DTH reakciót, melyet a talppárnák erőteljes duzzanata jelzett. A reakció az újraoltást követő 2. napon a legmarkánsabb, így a talpak vastagodását ebben az időpontban tüntettük fel. Ha az első ovalbumin oltás időpontjában klónozatlan, heterogén MSC kultúrát oltottunk az egerek hasüregébe, akkor az MSC-k szignifikánsan $(\mathrm{p}=0,0146)$ csökkentették a talppárnák ödémáját a csak ovalbuminnal oltott kontrollhoz képest (24. ábra).

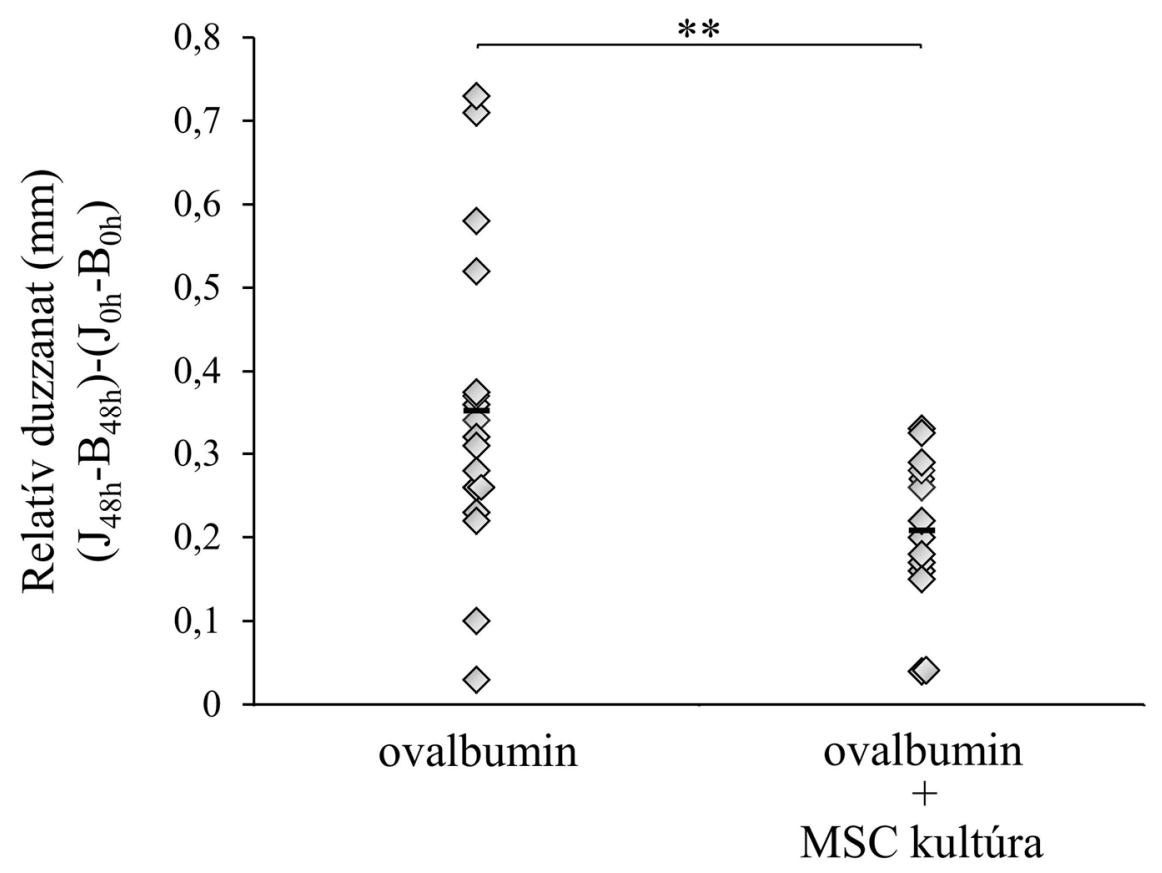

24. ábra. Az MSC kultúra immunszuppresszív hatása az ovalbumin indukálta késői típusú túlérzékenységi reakcióban. Him C57BL/6 egerek böre alá ovalbumint oltottunk, egyidejüleg a hasüregbe PBS-t vagy $10^{6}$ MSC-t oltottunk. Négy nap múlva höaggregált ovalbumint oltottunk az egerek jobb oldali hátsó talppárnájába (J) és PBS-t a bal oldali hátsó talppárnájába (B). Negyvennyolc óra után mértük az egerek talppárnájának vastagodását (mm). Az ábra 6 független kísérlet adatait tartalmazza $(n=17 ; n=14)$.

Az MSC2 és MSC6 klónok in vivo immunszuppresszív aktivitását az ovalbumin által kiváltott DTH reakció gátlásában vizsgáltuk. Az MSC2-vel történő oltás szignifikánsan csökkentette az ovalbumin által kiváltott talppárna duzzanatot $(\mathrm{p}<0,01)$, míg az MSC6-tal történő oltás nem befolyásolta a talpödémát. Ha azonban az MSC6 klónt a beoltást megelőzően 24 óráig kezeltük IFN- $\gamma$-val és TNF- $\alpha$-val, az MSC6 az MSC2-höz 
hasonlóan szignifikánsan $(\mathrm{p}<0,05)$ csillapította a talppárnák duzzanatát (25. ábra). Az erősen immunszuppresszív MSC2 hatása nem változott citokin előkezelés hatására (nem bemutatott adat).

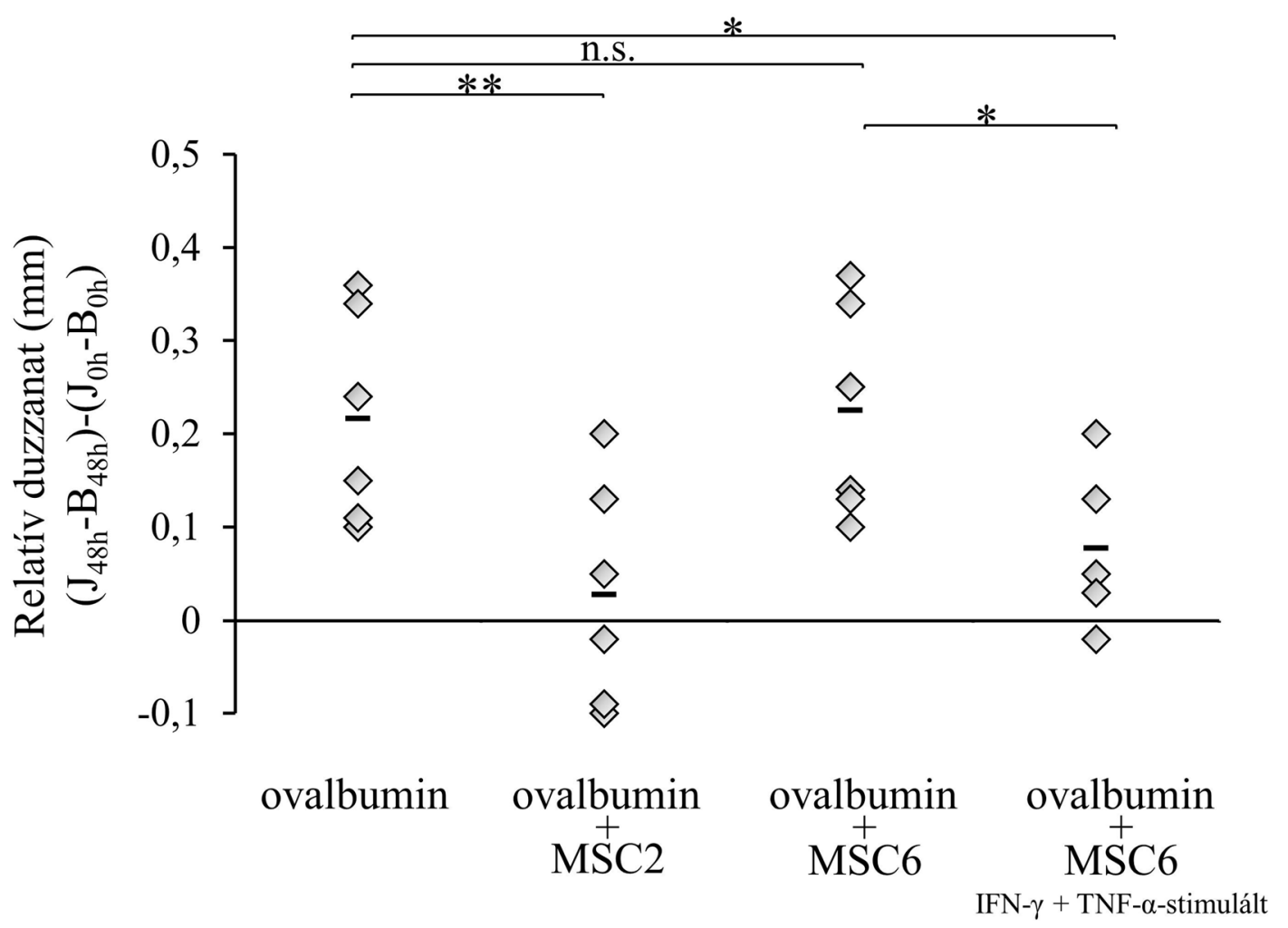

25. ábra. Az MSC2 és MSC6 hatása az ovalbumin által kiváltott DTH reakcióra. Hím $C 57 B L / 6$ egerek böre alá ovalbumint oltottunk, egyidejüleg a hasüregbe PBS-t vagy $10^{6}$ MSC2-t, MSC6-ot, illetve 24 óráig $100 \mathrm{ng} / \mathrm{mL} I F N$ - $\gamma$-val és $50 \mathrm{ng} / \mathrm{mL} T N F$ - $\alpha$-val elökezelt MSC6-ot oltottunk. Négy nap múlva höaggregált ovalbumint oltottunk az egerek jobb oldali hátsó talppárnájába (J) és PBS-t a bal oldali hátsó talppárnájába (B). Negyvennyolc óra után mértük az egerek talppárnájának vastagodását (mm). Az ábra 2 független kisérlet adatait tartalmazza $(n=5-6)$. 


\section{Következtetések}

A mesenchymalis őssejteket ezidáig több száz különböző célú klinikai vizsgálatba vonták be, melyek kimenetele meglehetősen változatos képet mutatott (46). Egyik feltételezett tényező ennek hátterében az MSC-k heterogenitása (157). Több, egy sejt eredetủ MSC klónnal végzett tanulmány kimutatta, hogy az MSC klónok mesenchymalis irányokba történő differenciálódási képessége eltérő (146). Más tulajdonságok, mint például a klónok proangiogén funkciója kevésbé került a heterogenitási vizsgálatok látómezöjébe, továbbá az immunszuppresszív funkciót érintő heterogenitást illetően sincs egyetértés a területen, mivel az ilyen irányú vizsgálatok száma csekély és eredményeik ellentmondásosak. Míg Xu és kollégái szerint az MSC klónok immunmodulációs képessége hasonló (113), más csoportok jelentős eltérést mutattak ki a klónok ilyen funkciója között $(115,153,154)$.

A jelen értekezés tárgya az egér csontvelöi eredetủ MSC populáció egysejtszintü diverzitásának vizsgálata, melyben elsősorban az MSC klónok nem gyulladásos és gyulladásos környezet által befolyásolt in vitro és in vivo immunszuppresszív tulajdonságára összpontosítottunk. Emellett a jellemzés részeként vizsgáltuk, hogy a gyulladásos citokinek hogyan módosítják a klónok csontképző- és zsírsejt irányú differenciációját, valamint a proangiogén (érképző) hatását.

\section{VI.1. Az MSC-k differenciációja}

Az MSC-k a szöveti regenerációt részben úgy segíthetik, ha közvetlenül a sérült szövet irányába differenciálódnak. Vajon egy MSC populáció egyes sejtjeiből kialakuló kolóniák hasonló, vagy különböző mértékben képesek differenciálódni? Az általunk vizsgált MSC klónok in vitro csont irányú differenciációja különböző volt, ami összhangban van az eddig közölt humán és rágcsáló MSC klónok csont differenciációját érintő eredményekkel $(115,149,150,158)$. Zsírsejt irányba mindegyik MSC klón hasonlóan differenciálódott. A terápiás felhasználás során az MSC beépülésnek és szövetirányú differenciálódásnak sok esetben olyan szövetben kell megvalósulnia, mely erőteljes gyulladásban van. Így a differenciálódási képesség vizsgálata gyulladásos mikrokörnyezetben alapvető fontosságú. A vizsgált MSC klónok gyulladásos citokinekkel (IFN- $\gamma$ és TNF- $\alpha$ ) történő elökezelés után nem differenciálódtak csont irányba, és a gyulladásos citokinek csökkentették a csont differenciációt szabályozó és jelző gének 
(Runx2, Bglap, Spp1) kifejeződését is. Ez az eredmény összhangban van azokkal a tanulmányokkal, melyek szerint a TNF- $\alpha$ gátolja az in vitro csont irányú differenciálódást (129-132), viszont ellentmond azoknak az eredményeknek, melyek szerint a TNF- $\alpha$ önmagában vagy IL-17-el kombinálva fokozza a csont irányú differenciációt $(133,134)$. A fenti ellentmondásra magyarázatul szolgálhat, hogy a szerzők eltérő citokinkoncentrációt alkalmaztak. Az alacsony citokinkoncentráció ugyanis serkentő, míg a magas gátló hatású $(131,135)$. In vivo állatmodellben, vad típusú egérben az IFN- $\gamma$-t és TNF- $\alpha$-t semlegesítő ellenanyagok fokozzák az MSC csont differenciációját (131), mely az általunk kapott eredményt támasztja alá.

\section{VI.2. Az MSC-k proangiogén funkciója}

A sérült szövetek megújulásánál sok esetben szükség van új erek képződésére is. Az elmúlt években bebizonyosodott, hogy az MSC-k által termelt faktorok palettája rendkívül széles, melyek között találhatunk endotélsejtek növekedésére és érképző folyamataira ható molekulákat is (159). Ezáltal in vitro modellrendszerben az MSC-k előidézik az endotélsejtek rendeződését kapilláris-szerü struktúrákba (23,65). Ezzel összhangban mi magunk is kimutattuk, hogy az MSC-k H5V endotélsejtekkel spontán módon, összefüggő prevascularis hálózatot alakítanak ki, melynek kiterjedtsége függ attól, hogy az MSC termel-e galektin-1 fehérjét (71). Kérdés, hogy az MSC sejtpopulációban az egyes sejtek hasonlóan vagy eltérően támogatják-e az angiogenezist az in vitro prevascularis modellben. A klónozás során nyert monoklonális MSC (MSC2-MSC6) sejtek hasonló mértékben képeznek prevascularis struktúrákat a H5V endotélsejtekkel, és ennek megfelelően a klónokban a proangiogén faktorok, Vegfa, Angpt1 és Lgals1 mRNS kifejeződése is hasonló. Az MSC-k terápiás alkalmazása folyamán a sérülés helyére jutó MSC proangiogén hatását módosíthatja a gyulladásos mikrokörnyezet. Az általunk vizsgált klónok gyulladáskeltő citokinek (IFN- $\gamma$ és TNF- $\alpha$ ) jelenlétében nem, vagy nagyon csekély számú prevascularis struktúrát képeztek endotélsejtekkel együtt tenyésztve. További vizsgálatok szükségesek annak megértésére, hogy a gyulladásos citokinek hogyan befolyásolják az MSC-k érképződést serkentő faktortermelését. Egy tanulmány arról számol be, hogy az IFN- $\gamma /$ TNF- $\alpha$-előkezelt MSC-kben megnő a VEGF és hipoxia indukálta faktor-1 $\alpha$ szekréciója, mely hozzájárulhat ahhoz, hogy a citokinekkel elökezelt MSC-k jobban elösegítik a tumornövekedést és -érképződést (137). 
Eredményeinkből az látszik, hogy a gyulladásos környezet gátolja az MSC-k differenciálódási és proangiogén hatását. Ezek alapján felmerül a kérdés, hogy azoknál a terápiáknál, melyeknél feltételezzük, hogy az MSC differenciációja vagy proangiogén hatása fontos szereppel bír, javasolt lehet-e a gyulladás csökkentése az MSC transzplantációt megelőzően? Véleményünk szerint fontos lenne ennek a kérdésnek a megválaszolása állatkísérletes betegségmodellek segítségével.

\section{VI.3. Az MSC-k immunszuppresszív funkciója}

A Ph.D. dolgozatomban leírt munkának a fő irányvonala az MSC immunmoduláló képességének egysejtszintű (klonális) vizsgálata. Az izolált MSC klónok különböző mértékben gátolták a ConA-aktivált T-sejtek osztódását, ahol a gátlás mértéke 30\%-tól 70\%-ig terjedt. Az MSC2, MSC4 és MSC5 klónok nagy mértékig gátolták a T-sejtek proliferációját, míg az MSC3 és MSC6 klónok általi gátlás szignifikánsan gyengébb volt. Ez az eredmény illeszkedik a mások által publikált adatok sorába $(115,153,154)$, melyek az egy sejt eredetü MSC klónok immunszuppresszív képességének különbségeiről adnak számot. A T-sejt proliferáció gátlásában megfigyelt sokféleség a Nos2 immunmodulációs gén klónonként változó szintű kifejeződésével magyarázható. A Nos2 által kódolt enzim funkciója a NO előállítása. Az erős gátlást mutató MSC2 és MSC5 klónok esetén mintegy 3 nagyságrenddel (a relatív mRNS különbség: 3338, illetve 1991), az MSC4 klónban pedig 2 nagyságrenddel (a relatív mRNS különbség 127) magasabban fejeződött ki a Nos2, mint a csekély gátlást mutató MSC3-ban. A Nos2 expresszió nem volt detektálható a legkevésbé gátló MSC6-ban. A klónokban mért különböző Nos2 mRNS expresszió hátterében sok tényező állhat. Egyrészt a Nos 2 gén átírását számos aktiváló és gátló hatású transzkripciós faktor szabályozza, melyek eltérő működése az egyes MSC klónokban különböző Nos2 transzkripcióhoz vezethet (160). A különbség a Nos2 mRNS molekula poszttranszkripcionális szabályozásából is fakadhat, az mRNS stabilitást szabályozó faktorok mint a heterogén nukleáris ribonukleoprotein I és L (hnRNPI/L) komplex eltérő kötődésével is magyarázható lehet (161). A NO T-sejt proliferáció gátlásban betöltött központi szerepét a NOS2 gátlószer, az L-NMMA használatával megerősítettük, mely visszafordította a legkifejezettebben gátló MSC2 klón hatását. Ennek a kísérletnek az eredménye egyezik a mások által, a teljes MSC populációval kapcsolatban leírtakkal $(114,115,153)$. A PGE2 szintézisben részt vevő enzimet kódoló Ptgs2 gén kifejeződésében nem találtunk szignifikáns különbséget a klónok között. Az egér MSC 
immunszuppressziójának mechanizmusában a PGE2 szerepét ellentmondó adatok övezik, melyek értelmében a PGE2-nek fontos (91) vagy mellékes (114) szerep jut, míg mások szerint egyáltalán nem járul hozzá a folyamathoz $(113,115,153)$. A PTGS2 gátlószer, az indometacin a mi kísérleteink szerint részben gátolta a T-sejt proliferációt, ezzel alátámasztva a PGE2 bizonyos fokú szerepét.

Egyre nő azoknak az irodalmi adatoknak a száma, melyek azt támasztják alá, hogy az MSC-ket övező gyulladásos mikrokörnyezet erőteljesen befolyásolja az MSC-k biológiai funkcióját. A gyulladás helyén az immunsejtek által termelt gyulladásos citokinek $(115,127)$ általi aktivációt idegen szóval „licensing”-nek nevezzük $(128)$, mely a dolgozatban az általunk alkotott citokinavatás kifejezésként szerepel. A citokinavatás az MSC-ket gyulladáscsökkentő fenotípus irányába tolja el, mely függ a felhasznált faktor típusától, koncentrációjától és a kezelés időtartamától (128). A gyulladásos környezet modellezésére és ezáltal az MSC-k gátló hatásának serkentésére az IFN- $\gamma$ és a TNF- $\alpha$ citokinek kombinációját választottuk. Az MSC kultúra előkezelése IFN- $\gamma$-val és TNF- $\alpha$-val együttesen számottevően megemelte a Nos $2\left(2^{\Delta \Delta \text { CtIFN- } \gamma \mathrm{TNF}-\alpha \gamma}=4705\right)$, illetve indukálta az Ido1 gének kifejeződését, és a citokinavatás kis mértékben növelte a Ptgs2 gén kifejeződését $\left(2^{\triangle \Delta C t I F N-\gamma \mathrm{TNF}-\alpha}=7,62\right)$ is. Következésképpen a citokinavatott MSC kultúra Tsejt proliferáció gátló képessége szignifikánsan megnőtt a kezeletlen MSC-éhez képest. Az MSC klónok IFN- $\gamma$ és TNF- $\alpha$ kezelése is serkentő hatású volt, és ilyen módon kiegyenlítette a klónok közti különbségeket, melyek a T-sejt osztódás gátlásában mutatkoztak, így a gyengén gátló MSC3 és MSC6 klónok elérték a kiemelkedően gátló MSC2, MSC4 és MSC5 klónok szintjét T-sejt osztódás gátlást illetően. Ez az eredmény arra mutat rá, hogy az IFN- $\gamma$ és TNF- $\alpha$ kezelés stimulálja a funkcióképtelen MSC klónok immunválaszt gátló képességét. Az MSC kultúránál megfigyeltekhez hasonló módon a citokinavatás az MSC klónokban is markánsan növelte a Nos2 és az Ido1 és közepesen fokozta a Ptgs 2 gének kifejeződését. Az a megfigyelésünk, hogy a citokinavatás minden klónban egyöntetűen indukálja a Nos2 mRNS expressziót, arra enged következtetni, hogy a stimulálatlan klónok közötti Nos2 mRNS expressziós különbségek nem a Nos2 génben történő mutációból fakadnak.

A citokinek által erőteljesen indukált Nos2 valóban szerepet játszik az MSC klónok által T-sejtekre kifejtett osztódásgátlásban, ugyanis specifikus gátlószerével, az L-NMMAval a citokinavatott MSC2 és MSC6 müködése gátolható volt. A PTGS2 indometacinnal történő gátlása részben megszüntette az MSC6 immunszuppresszív képességét, az MSC2- 
ére azonban a gátlószer hatástalannak bizonyult. Ebből azt a következtetést vonhattuk le, hogy az MSC populáción belül nem egységes az immunszuppressziót szolgáló különbözö faktorok, mint a PTGS2 szerepe.

Az Ido1 mRNS kifejeződésének indukciója volt a legszembetűnőbb változás, amelyet a gyulladásos körülmények közt tapasztaltunk, hiszen a stimulálatlan MSC kultúra és az MSC klónok ezt a gént egyáltalán nem fejezték ki. Ugyanakkor az IFN- $\gamma$ és az IFN- $\gamma$ és TNF- $\alpha$ kombinációja indukálta az Ido1 mRNS kifejeződését az MSC kultúrában, illetve a klónokban. A magas Ido1 expresszió ellenére az IDO1 specifikus gátlószere, az 1-MT nem volt hatással a citokinavatott MSC klónok immunszuppresszív képességére. Jóllehet a humán MSC egyik legfontosabb immunmoduláló faktora az IDO1 $(99,110)$, egér MSC-ben a szerepe nem egyértelmü. Még ha a gyulladásos citokinek előidézték is az Idol mRNS kifejeződését, az IDO1 fehérje egér MSC-ben nem volt kimutatható (125). Ennek megfelelően az IDO1 termelés gátlása nem oldotta fel az egér MSC T-sejt osztódás gátló hatását $(99,114,115)$. Erre talán magyarázatot nyújthat az a megfigyelés, hogy egy epitél karcinóma sejtvonalban az NO felszabadulása előidézte az IDO1 gyors proteaszómás lebomlását (162). Elképzelhető, hogy az IDO1 az NO hatására az egér MSC-ben is lebontásra kerül, ennek igazolására azonban további kísérletek szükségesek.

Az MSC-k in vitro T-sejt proliferációt gátló és így immunszuppresszív hatását az in vivo állatmodellek is alátámasztják $(72,95,118,142,143)$, mely felveti annak a lehetőségét, hogy az MSC sejtterápia alkalmas lehet különböző immunológiai kórképek kezelésére. Az MSC-k in vivo immunmoduláló hatását mi is igazoltuk egy ovalbumin által kiváltott késői típusú túlérzékenységi reakcióban. Az MSC kultúra eredményesen csökkentette az egerek ovalbumin oltás által elöidézett talppárna duzzanatát. Ugyanebben az in vivo rendszerben azt is kimutattuk, hogy az in vitro T-sejt osztódást a legerősebben és legkevésbé gátló MSC2, illetve MSC6 klón sikeresen (MSC2), illetve gyengén (MSC6) gátolta a DTH reakciót. Az in vitro eredményeket igazolta az is, hogy IFN- $\gamma$-val és TNF- $\alpha$-val elökezelt MSC6 az MSC2-klónhoz hasonlóan csillapította a talpak ödémáját jelezvén, hogy a gyenge hatású stimulálatlan MSC6 klón immunszuppresszív képessége a citokinavatás révén megnőtt. Eredményeink alátámasztják azokat a GVHD egérmodelljével végzett kísérleteket, melyekben a betegség kialakulásának megelőzésében az IFN- $\gamma$-val előaktivált MSC oltása hatásosabbnak bizonyult, mint a kezeletlen MSC-vel való oltás (143). 


\section{VI.3. Összefoglalás}

Munkánk összegzéseként megállapíthatjuk, hogy az egér csontvelői MSC populáción belül az immunmoduláló képességet illetően sokféleség uralkodik az egy sejt eredetű klónok között. Az MSC klónok közötti különbségek részben az immunregulatív faktorok előállításáért felelős enzimeket kódoló gének eltérő kifejeződésével magyarázhatóak. Ebben a tekintetben, az NO a meghatározó szerepű faktor, a PGE2 részt vesz a klónok által kifejtett immunszuppresszióban, míg az IDO1-nek nincs szerepe benne. Ennek a munkának az egyik fontos üzenete az, hogy a gyulladásos környezetben található citokinek úgy mint az IFN- $\gamma$ és a TNF- $\alpha$ eltolják, polarizálják az MSC-ket egy erőteljesen immunszuppresszív fenotípus irányába, míg differenciálódási képességük és érképződést elősegítő hatásuk gyengül, vagy teljesen meg is szünik (26. ábra). Gyulladásos citokinekkel való kezeléssel, ún. citokinavatással, az MSC klónok közötti immunfunkciót illető különbségek eltüntethetőek. Érdemes megfontolni ennek a vizsgálatnak az eredményeit az immunológiai terápiás felhasználást megelőzően, illetve felvetődik a kérdés, hogy regeneratív orvoslásban az MSC-k szövetregenerációt elősegítő hatását lehetne-e fokozni a sérülés helyén fellépő gyulladás enyhítése által.

\begin{tabular}{|c|c|c|c|c|}
\hline \multicolumn{2}{|r|}{ Nem stimulált } & \multicolumn{3}{|c|}{ IFN- $\gamma /$ TNF- $\alpha$-stimulált } \\
\hline & MSC2 & MSC2 & MSC6 & $\begin{array}{c}\text { Citokinkezelés } \\
\text { hatása }\end{array}$ \\
\hline $\begin{array}{l}\text { Csontképző sejt } \\
\text { differenciáció }\end{array}$ & $\begin{array}{c}+++ \\
\text { különböző }\end{array}$ & & - & \\
\hline $\begin{array}{l}\text { Prevascularis } \\
\text { struktúra teszt }\end{array}$ & $\begin{array}{c}++++\quad+++++ \\
\text { hasonló } \\
\end{array}$ & - & - & \\
\hline $\begin{array}{c}\text { T-sejt proliferáció } \\
\text { gátlás }\end{array}$ & $\begin{array}{c}+++++ \\
\text { különböző }\end{array}$ & $\begin{array}{r}+++++ \\
h\end{array}$ & $\begin{array}{l}\text { +++++ } \\
\text { ló }\end{array}$ & \\
\hline $\begin{array}{l}\text { DTH reakció } \\
\text { gátlás }\end{array}$ & $\begin{array}{c}+++++ \\
\text { különböző }\end{array}$ & $\begin{array}{r}+++++ \\
h\end{array}$ & $\begin{array}{l}\text { +++++ } \\
\text { ló }\end{array}$ & \\
\hline
\end{tabular}

26. ábra. A gyulladásos környezet hatása az MSC2 és MSC6 klónok funkcióira. A jelek száma arra utal, hogy az MSC-k az adott funkcót milyen mértékben képesek véghez vinni. A - jel a funkció hiányát jelzi. A nyilak szine és iránya a citokinkezelés hatását jelzi az adott MSC funcióra: piros, lefelé mutató nyíl - funkció csökkenés; zöld, felfelé mutató nyíl funkció növekedés. 


\section{Irodalomjegyzék}

1. Friedenstein, A. J., Chailakhyan, R. K., and Gerasimov, U. V. (1987) Bone marrow osteogenic stem cells: in vitro cultivation and transplantation in diffusion chambers. Cell and tissue kinetics 20, 263-272

2. Bianco, P., Riminucci, M., Gronthos, S., and Robey, P. G. (2001) Bone marrow stromal stem cells: nature, biology, and potential applications. Stem cells (Dayton, Ohio) 19, 180-192

3. Sacchetti, B., Funari, A., Michienzi, S., Di Cesare, S., Piersanti, S., Saggio, I., Tagliafico, E., Ferrari, S., Robey, P. G., Riminucci, M., and Bianco, P. (2007) Selfrenewing osteoprogenitors in bone marrow sinusoids can organize a hematopoietic microenvironment. Cell 131, 324-336

4. Caplan, A. I. (1991) Mesenchymal stem cells. Journal of orthopaedic research : official publication of the Orthopaedic Research Society 9, 641-650

5. De Bari, C., Dell'Accio, F., Tylzanowski, P., and Luyten, F. P. (2001) Multipotent mesenchymal stem cells from adult human synovial membrane. Arthritis and rheumatism 44, 1928-1942

6. Kuznetsov, S. A., Mankani, M. H., Gronthos, S., Satomura, K., Bianco, P., and Robey, P. G. (2001) Circulating skeletal stem cells. The Journal of cell biology 153, 1133-1140

7. Zuk, P. A., Zhu, M., Mizuno, H., Huang, J., Futrell, J. W., Katz, A. J., Benhaim, P., Lorenz, H. P., and Hedrick, M. H. (2001) Multilineage cells from human adipose tissue: implications for cell-based therapies. Tissue engineering 7, 211-228

8. Salingcarnboriboon, R., Yoshitake, H., Tsuji, K., Obinata, M., Amagasa, T., Nifuji, A., and Noda, M. (2003) Establishment of tendon-derived cell lines exhibiting pluripotent mesenchymal stem cell-like property. Experimental cell research 287, 289-300

9. Alsalameh, S., Amin, R., Gemba, T., and Lotz, M. (2004) Identification of mesenchymal progenitor cells in normal and osteoarthritic human articular cartilage. Arthritis and rheumatism 50, 1522-1532

10. Lee, O. K., Kuo, T. K., Chen, W. M., Lee, K. D., Hsieh, S. L., and Chen, T. H. (2004) Isolation of multipotent mesenchymal stem cells from umbilical cord blood. Blood 103, 1669-1675

11. Seo, B. M., Miura, M., Gronthos, S., Bartold, P. M., Batouli, S., Brahim, J., Young, M., Robey, P. G., Wang, C. Y., and Shi, S. (2004) Investigation of multipotent postnatal stem cells from human periodontal ligament. Lancet 364, 149-155

12. Tsai, M. S., Lee, J. L., Chang, Y. J., and Hwang, S. M. (2004) Isolation of human multipotent mesenchymal stem cells from second-trimester amniotic fluid using a novel two-stage culture protocol. Human reproduction (Oxford, England) 19, 14501456

13. da Silva Meirelles, L., Chagastelles, P. C., and Nardi, N. B. (2006) Mesenchymal stem cells reside in virtually all post-natal organs and tissues. Journal of cell science 119, 2204-2213

14. Kolf, C. M., Cho, E., and Tuan, R. S. (2007) Mesenchymal stromal cells. Biology of adult mesenchymal stem cells: regulation of niche, self-renewal and differentiation. Arthritis research \& therapy 9, 204

15. Boxall, S. A., and Jones, E. (2012) Markers for characterization of bone marrow multipotential stromal cells. Stem cells international 2012, 975871 
16. Peister, A., Mellad, J. A., Larson, B. L., Hall, B. M., Gibson, L. F., and Prockop, D. J. (2004) Adult stem cells from bone marrow (MSCs) isolated from different strains of inbred mice vary in surface epitopes, rates of proliferation, and differentiation potential. Blood 103, 1662-1668

17. Hegyi, B., Sagi, B., Kovacs, J., Kiss, J., Urban, V. S., Meszaros, G., Monostori, E., and Uher, F. (2010) Identical, similar or different? Learning about immunomodulatory function of mesenchymal stem cells isolated from various mouse tissues: bone marrow, spleen, thymus and aorta wall. International immunology 22, 551-559

18. Dominici, M., Le Blanc, K., Mueller, I., Slaper-Cortenbach, I., Marini, F., Krause, D., Deans, R., Keating, A., Prockop, D., and Horwitz, E. (2006) Minimal criteria for defining multipotent mesenchymal stromal cells. The International Society for Cellular Therapy position statement. Cytotherapy 8, 315-317

19. Halfon, S., Abramov, N., Grinblat, B., and Ginis, I. (2011) Markers distinguishing mesenchymal stem cells from fibroblasts are downregulated with passaging. Stem cells and development 20, 53-66

20. Caplan, A. I., and Correa, D. (2011) The MSC: an injury drugstore. Cell stem cell 9, 11-15

21. Caplan, A. I. (2008) All MSCs are pericytes? Cell stem cell 3, 229-230

22. Rehman, J., Traktuev, D., Li, J., Merfeld-Clauss, S., Temm-Grove, C. J., Bovenkerk, J. E., Pell, C. L., Johnstone, B. H., Considine, R. V., and March, K. L. (2004) Secretion of angiogenic and antiapoptotic factors by human adipose stromal cells. Circulation 109, 1292-1298

23. Sorrell, J. M., Baber, M. A., and Caplan, A. I. (2009) Influence of adult mesenchymal stem cells on in vitro vascular formation. Tissue engineering. Part A 15, 1751-1761

24. Bernardo, M. E., and Fibbe, W. E. (2013) Mesenchymal stromal cells: sensors and switchers of inflammation. Cell stem cell 13, 392-402

25. Lazarus, H. M., Haynesworth, S. E., Gerson, S. L., Rosenthal, N. S., and Caplan, A. I. (1995) Ex vivo expansion and subsequent infusion of human bone marrowderived stromal progenitor cells (mesenchymal progenitor cells): implications for therapeutic use. Bone marrow transplantation 16, 557-564

26. Wei, X., Yang, X., Han, Z. P., Qu, F. F., Shao, L., and Shi, Y. F. (2013) Mesenchymal stem cells: a new trend for cell therapy. Acta pharmacologica Sinica 34, 747-754

27. Swart, J. F., and Wulffraat, N. M. (2014) Mesenchymal stromal cells for treatment of arthritis. Best practice \& research. Clinical rheumatology 28, 589-603

28. Wang, Y., Yuan, M., Guo, Q. Y., Lu, S. B., and Peng, J. (2014) Mesenchymal stem cells for treating articular cartilage defects and osteoarthritis. Cell transplantation

29. Sun, L., Akiyama, K., Zhang, H., Yamaza, T., Hou, Y., Zhao, S., Xu, T., Le, A., and Shi, S. (2009) Mesenchymal stem cell transplantation reverses multiorgan dysfunction in systemic lupus erythematosus mice and humans. Stem cells (Dayton, Ohio) 27, 1421-1432

30. Sun, L., Wang, D., Liang, J., Zhang, H., Feng, X., Wang, H., Hua, B., Liu, B., Ye, S., Hu, X., Xu, W., Zeng, X., Hou, Y., Gilkeson, G. S., Silver, R. M., Lu, L., and Shi, S. (2010) Umbilical cord mesenchymal stem cell transplantation in severe and refractory systemic lupus erythematosus. Arthritis and rheumatism 62, 2467-2475 
31. Sui, W., Hou, X., Che, W., Chen, J., Ou, M., Xue, W., and Dai, Y. (2013) Hematopoietic and mesenchymal stem cell transplantation for severe and refractory systemic lupus erythematosus. Clinical immunology (Orlando, Fla.) 148, 186-197

32. Chen, S. L., Fang, W. W., Ye, F., Liu, Y. H., Qian, J., Shan, S. J., Zhang, J. J., Chunhua, R. Z., Liao, L. M., Lin, S., and Sun, J. P. (2004) Effect on left ventricular function of intracoronary transplantation of autologous bone marrow mesenchymal stem cell in patients with acute myocardial infarction. The American journal of cardiology 94, 92-95

33. Katritsis, D. G., Sotiropoulou, P. A., Karvouni, E., Karabinos, I., Korovesis, S., Perez, S. A., Voridis, E. M., and Papamichail, M. (2005) Transcoronary transplantation of autologous mesenchymal stem cells and endothelial progenitors into infarcted human myocardium. Catheterization and cardiovascular interventions : official journal of the Society for Cardiac Angiography \& Interventions 65, 321-329

34. Meyer, G. P., Wollert, K. C., Lotz, J., Pirr, J., Rager, U., Lippolt, P., Hahn, A., Fichtner, S., Schaefer, A., Arseniev, L., Ganser, A., and Drexler, H. (2009) Intracoronary bone marrow cell transfer after myocardial infarction: 5-year followup from the randomized-controlled BOOST trial. European heart journal 30, 29782984

35. Hare, J. M., Traverse, J. H., Henry, T. D., Dib, N., Strumpf, R. K., Schulman, S. P., Gerstenblith, G., DeMaria, A. N., Denktas, A. E., Gammon, R. S., Hermiller, J. B., Jr., Reisman, M. A., Schaer, G. L., and Sherman, W. (2009) A randomized, doubleblind, placebo-controlled, dose-escalation study of intravenous adult human mesenchymal stem cells (prochymal) after acute myocardial infarction. Journal of the American College of Cardiology 54, 2277-2286

36. Houtgraaf, J. H., den Dekker, W. K., van Dalen, B. M., Springeling, T., de Jong, R., van Geuns, R. J., Geleijnse, M. L., Fernandez-Aviles, F., Zijlsta, F., Serruys, P. W., and Duckers, H. J. (2012) First experience in humans using adipose tissuederived regenerative cells in the treatment of patients with ST-segment elevation myocardial infarction. Journal of the American College of Cardiology 59, 539-540

37. Dalal, J., Gandy, K., and Domen, J. (2012) Role of mesenchymal stem cell therapy in Crohn's disease. Pediatric research 71, 445-451

38. Amorin, B., Alegretti, A. P., Valim, V., Pezzi, A., Laureano, A. M., da Silva, M. A., Wieck, A., and Silla, L. (2014) Mesenchymal stem cell therapy and acute graftversus-host disease: a review. Human cell 27, 137-150

39. Shah, K. (2012) Mesenchymal stem cells engineered for cancer therapy. Advanced drug delivery reviews 64, 739-748

40. Pittenger, M., Vanguri, P., Simonetti, D., and Young, R. (2002) Adult mesenchymal stem cells: potential for muscle and tendon regeneration and use in gene therapy. Journal of musculoskeletal \& neuronal interactions 2, 309-320

41. Lee, J. Y., Zhou, Z., Taub, P. J., Ramcharan, M., Li, Y., Akinbiyi, T., Maharam, E. R., Leong, D. J., Laudier, D. M., Ruike, T., Torina, P. J., Zaidi, M., Majeska, R. J., Schaffler, M. B., Flatow, E. L., and Sun, H. B. (2011) BMP-12 treatment of adult mesenchymal stem cells in vitro augments tendon-like tissue formation and defect repair in vivo. PLoS One 6, e17531

42. Toma, C., Pittenger, M. F., Cahill, K. S., Byrne, B. J., and Kessler, P. D. (2002) Human mesenchymal stem cells differentiate to a cardiomyocyte phenotype in the adult murine heart. Circulation 105, 93-98 
43. Murphy, J. M., Fink, D. J., Hunziker, E. B., and Barry, F. P. (2003) Stem cell therapy in a caprine model of osteoarthritis. Arthritis and rheumatism 48, 34643474

44. Nagaya, N., Kangawa, K., Itoh, T., Iwase, T., Murakami, S., Miyahara, Y., Fujii, T., Uematsu, M., Ohgushi, H., Yamagishi, M., Tokudome, T., Mori, H., Miyatake, K., and Kitamura, S. (2005) Transplantation of mesenchymal stem cells improves cardiac function in a rat model of dilated cardiomyopathy. Circulation 112, 11281135

45. Granero-Molto, F., Weis, J. A., Miga, M. I., Landis, B., Myers, T. J., O'Rear, L., Longobardi, L., Jansen, E. D., Mortlock, D. P., and Spagnoli, A. (2009) Regenerative effects of transplanted mesenchymal stem cells in fracture healing. Stem cells (Dayton, Ohio) 27, 1887-1898

46. Murphy, M. B., Moncivais, K., and Caplan, A. I. (2013) Mesenchymal stem cells: environmentally responsive therapeutics for regenerative medicine. Exp Mol Med 45, e54

47. Tsuji, K., Bandyopadhyay, A., Harfe, B. D., Cox, K., Kakar, S., Gerstenfeld, L., Einhorn, T., Tabin, C. J., and Rosen, V. (2006) BMP2 activity, although dispensable for bone formation, is required for the initiation of fracture healing. Nature genetics 38, 1424-1429

48. Kim, H., Choi, S.-M., and Kim, H.-S. (2013) Mesenchymal stem cell-derived secretome and microvesicles as a cell-free therapeutics for neurodegenerative disorders. Tissue Eng Regen Med 10, 93-101

49. Baglio, S. R., Pegtel, D. M., and Baldini, N. (2012) Mesenchymal stem cell secreted vesicles provide novel opportunities in (stem) cell-free therapy. Frontiers in physiology 3, 359

50. Kinnaird, T., Stabile, E., Burnett, M. S., Shou, M., Lee, C. W., Barr, S., Fuchs, S., and Epstein, S. E. (2004) Local delivery of marrow-derived stromal cells augments collateral perfusion through paracrine mechanisms. Circulation 109, 1543-1549

51. Gnecchi, M., He, H., Noiseux, N., Liang, O. D., Zhang, L., Morello, F., Mu, H., Melo, L. G., Pratt, R. E., Ingwall, J. S., and Dzau, V. J. (2006) Evidence supporting paracrine hypothesis for Akt-modified mesenchymal stem cell-mediated cardiac protection and functional improvement. FASEB journal : official publication of the Federation of American Societies for Experimental Biology 20, 661-669

52. Parekkadan, B., van Poll, D., Suganuma, K., Carter, E. A., Berthiaume, F., Tilles, A. W., and Yarmush, M. L. (2007) Mesenchymal stem cell-derived molecules reverse fulminant hepatic failure. PLoS One 2, e941

53. Curley, G. F., Hayes, M., Ansari, B., Shaw, G., Ryan, A., Barry, F., O'Brien, T., O'Toole, D., and Laffey, J. G. (2012) Mesenchymal stem cells enhance recovery and repair following ventilator-induced lung injury in the rat. Thorax 67, 496-501

54. Chuang, T. J., Lin, K. C., Chio, C. C., Wang, C. C., Chang, C. P., and Kuo, J. R. (2012) Effects of secretome obtained from normoxia-preconditioned human mesenchymal stem cells in traumatic brain injury rats. The journal of trauma and acute care surgery 73, 1161-1167

55. Gatti, S., Bruno, S., Deregibus, M. C., Sordi, A., Cantaluppi, V., Tetta, C., and Camussi, G. (2011) Microvesicles derived from human adult mesenchymal stem cells protect against ischaemia-reperfusion-induced acute and chronic kidney injury. Nephrology, dialysis, transplantation : official publication of the European Dialysis and Transplant Association - European Renal Association 26, 1474-1483 
56. Pacini, S., and Petrini, I. (2014) Are MSCs angiogenic cells? New insights on human nestin-positive bone marrow-derived multipotent cells. Frontiers in cell and developmental biology 2, 20

57. Oswald, J., Boxberger, S., Jorgensen, B., Feldmann, S., Ehninger, G., Bornhauser, M., and Werner, C. (2004) Mesenchymal stem cells can be differentiated into endothelial cells in vitro. Stem cells (Dayton, Ohio) 22, 377-384

58. Liu, J. W., Dunoyer-Geindre, S., Serre-Beinier, V., Mai, G., Lambert, J. F., Fish, R. J., Pernod, G., Buehler, L., Bounameaux, H., and Kruithof, E. K. (2007) Characterization of endothelial-like cells derived from human mesenchymal stem cells. Journal of thrombosis and haemostasis : JTH 5, 826-834

59. Roobrouck, V. D., Clavel, C., Jacobs, S. A., Ulloa-Montoya, F., Crippa, S., Sohni, A., Roberts, S. J., Luyten, F. P., Van Gool, S. W., Sampaolesi, M., Delforge, M., Luttun, A., and Verfaillie, C. M. (2011) Differentiation potential of human postnatal mesenchymal stem cells, mesoangioblasts, and multipotent adult progenitor cells reflected in their transcriptome and partially influenced by the culture conditions. Stem cells (Dayton, Ohio) 29, 871-882

60. Jazayeri, M., Allameh, A., Soleimani, M., Jazayeri, S. H., Piryaei, A., and Kazemnejad, S. (2008) Molecular and ultrastructural characterization of endothelial cells differentiated from human bone marrow mesenchymal stem cells. Cell biology international 32, 1183-1192

61. Crisan, M., Yap, S., Casteilla, L., Chen, C. W., Corselli, M., Park, T. S., Andriolo, G., Sun, B., Zheng, B., Zhang, L., Norotte, C., Teng, P. N., Traas, J., Schugar, R., Deasy, B. M., Badylak, S., Buhring, H. J., Giacobino, J. P., Lazzari, L., Huard, J., and Peault, B. (2008) A perivascular origin for mesenchymal stem cells in multiple human organs. Cell stem cell 3, 301-313

62. Blocki, A., Wang, Y., Koch, M., Peh, P., Beyer, S., Law, P., Hui, J., and Raghunath, M. (2013) Not all MSCs can act as pericytes: functional in vitro assays to distinguish pericytes from other mesenchymal stem cells in angiogenesis. Stem cells and development 22, 2347-2355

63. Hoshino, A., Chiba, H., Nagai, K., Ishii, G., and Ochiai, A. (2008) Human vascular adventitial fibroblasts contain mesenchymal stem/progenitor cells. Biochem Biophys Res Commun 368, 305-310

64. Au, P., Tam, J., Fukumura, D., and Jain, R. K. (2008) Bone marrow-derived mesenchymal stem cells facilitate engineering of long-lasting functional vasculature. Blood 111, 4551-4558

65. Wu, Y., Chen, L., Scott, P. G., and Tredget, E. E. (2007) Mesenchymal stem cells enhance wound healing through differentiation and angiogenesis. Stem cells (Dayton, Ohio) 25, 2648-2659

66. Hung, S. C., Pochampally, R. R., Chen, S. C., Hsu, S. C., and Prockop, D. J. (2007) Angiogenic effects of human multipotent stromal cell conditioned medium activate the PI3K-Akt pathway in hypoxic endothelial cells to inhibit apoptosis, increase survival, and stimulate angiogenesis. Stem cells (Dayton, Ohio) 25, 2363-2370

67. Togel, F., Weiss, K., Yang, Y., Hu, Z., Zhang, P., and Westenfelder, C. (2007) Vasculotropic, paracrine actions of infused mesenchymal stem cells are important to the recovery from acute kidney injury. American journal of physiology. Renal physiology 292, F1626-1635

68. Duffy, G. P., Ahsan, T., O'Brien, T., Barry, F., and Nerem, R. M. (2009) Bone marrow-derived mesenchymal stem cells promote angiogenic processes in a timeand dose-dependent manner in vitro. Tissue engineering. Part A 15, 2459-2470 
69. Potapova, I. A., Gaudette, G. R., Brink, P. R., Robinson, R. B., Rosen, M. R., Cohen, I. S., and Doronin, S. V. (2007) Mesenchymal stem cells support migration, extracellular matrix invasion, proliferation, and survival of endothelial cells in vitro. Stem cells (Dayton, Ohio) 25, 1761-1768

70. Boomsma, R. A., and Geenen, D. L. (2012) Mesenchymal stem cells secrete multiple cytokines that promote angiogenesis and have contrasting effects on chemotaxis and apoptosis. PLoS One 7, e35685

71. Szebeni, G. J., Kriston-Pál, É., Blazsó, P., Katona, R. L., Novák, J., Szabó, E., Czibula, Á., Fajka-Boja, R., Hegyi, B., Uher, F., Krenács, L., Joó, G., and Monostori, É. (2012) Identification of Galectin-1 as a Critical Factor in Function of Mouse Mesenchymal Stromal Cell-Mediated Tumor Promotion. PLoS ONE 7, e41372

72. Bartholomew, A., Sturgeon, C., Siatskas, M., Ferrer, K., McIntosh, K., Patil, S., Hardy, W., Devine, S., Ucker, D., Deans, R., Moseley, A., and Hoffman, R. (2002) Mesenchymal stem cells suppress lymphocyte proliferation in vitro and prolong skin graft survival in vivo. Experimental hematology 30, 42-48

73. Mendez-Ferrer, S., Michurina, T. V., Ferraro, F., Mazloom, A. R., MacArthur, B. D., Lira, S. A., Scadden, D. T., Ma/'ayan, A., Enikolopov, G. N., and Frenette, P. S. (2010) Mesenchymal and haematopoietic stem cells form a unique bone marrow niche. Nature 466, 829-834

74. Haniffa, M. A., Wang, X. N., Holtick, U., Rae, M., Isaacs, J. D., Dickinson, A. M., Hilkens, C. M., and Collin, M. P. (2007) Adult human fibroblasts are potent immunoregulatory cells and functionally equivalent to mesenchymal stem cells. Journal of immunology (Baltimore, Md. : 1950) 179, 1595-1604

75. Jones, S., Horwood, N., Cope, A., and Dazzi, F. (2007) The antiproliferative effect of mesenchymal stem cells is a fundamental property shared by all stromal cells. Journal of immunology (Baltimore, Md. : 1950) 179, 2824-2831

76. Huber, L. C., Distler, O., Tarner, I., Gay, R. E., Gay, S., and Pap, T. (2006) Synovial fibroblasts: key players in rheumatoid arthritis. Rheumatology (Oxford, England) 45, 669-675

77. Martinez, F. O., and Gordon, S. (2014) The M1 and M2 paradigm of macrophage activation: time for reassessment. F1000Prime Reports 6, 13

78. Kim, J., and Hematti, P. (2009) Mesenchymal stem cell-educated macrophages: a novel type of alternatively activated macrophages. Experimental hematology 37, 1445-1453

79. Cho, D. I., Kim, M. R., Jeong, H. Y., Jeong, H. C., Jeong, M. H., Yoon, S. H., Kim, Y. S., and Ahn, Y. (2014) Mesenchymal stem cells reciprocally regulate the M1/M2 balance in mouse bone marrow-derived macrophages. Exp Mol Med 46, e70

80. Witko-Sarsat, V., Rieu, P., Descamps-Latscha, B., Lesavre, P., and HalbwachsMecarelli, L. (0000) Neutrophils: Molecules, Functions and Pathophysiological Aspects. Lab Invest 80, 617-653

81. Raffaghello, L., Bianchi, G., Bertolotto, M., Montecucco, F., Busca, A., Dallegri, F., Ottonello, L., and Pistoia, V. (2008) Human mesenchymal stem cells inhibit neutrophil apoptosis: a model for neutrophil preservation in the bone marrow niche. Stem cells (Dayton, Ohio) 26, 151-162

82. Brandau, S., Jakob, M., Bruderek, K., Bootz, F., Giebel, B., Radtke, S., Mauel, K., Jager, M., Flohe, S. B., and Lang, S. (2014) Mesenchymal stem cells augment the anti-bacterial activity of neutrophil granulocytes. PLoS One 9, e106903 
83. Sotiropoulou, P. A., Perez, S. A., Gritzapis, A. D., Baxevanis, C. N., and Papamichail, M. (2006) Interactions between human mesenchymal stem cells and natural killer cells. Stem cells (Dayton, Ohio) 24, 74-85

84. Spaggiari, G. M., Capobianco, A., Abdelrazik, H., Becchetti, F., Mingari, M. C., and Moretta, L. (2008) Mesenchymal stem cells inhibit natural killer-cell proliferation, cytotoxicity, and cytokine production: role of indoleamine 2,3dioxygenase and prostaglandin E2. Blood 111, 1327-1333

85. Thomas, H., Jager, M., Mauel, K., Brandau, S., Lask, S., and Flohe, S. B. (2014) Interaction with mesenchymal stem cells provokes natural killer cells for enhanced IL-12/IL-18-induced interferon-gamma secretion. Mediators of inflammation 2014, 143463

86. Chiesa, S., Morbelli, S., Morando, S., Massollo, M., Marini, C., Bertoni, A., Frassoni, F., Bartolome, S. T., Sambuceti, G., Traggiai, E., and Uccelli, A. (2011) Mesenchymal stem cells impair in vivo T-cell priming by dendritic cells. Proceedings of the National Academy of Sciences of the United States of America 108, 17384-17389

87. Zhang, Y., Cai, W., Huang, Q., Gu, Y., Shi, Y., Huang, J., Zhao, F., Liu, Q., Wei, X., Jin, M., Wu, C., Xie, Q., Zhang, Y., Wan, B., and Zhang, Y. (2014) Mesenchymal stem cells alleviate bacteria-induced liver injury in mice by inducing regulatory dendritic cells. Hepatology (Baltimore, Md.) 59, 671-682

88. Franquesa, M., Hoogduijn, M. J., Bestard, O., and Grinyó, J. M. (2012) Immunomodulatory effect of Mesenchymal Stem Cells on B cells. Frontiers in Immunology 3

89. Zhou, K., Zhang, H., Jin, O., Feng, X., Yao, G., Hou, Y., and Sun, L. (2008) Transplantation of human bone marrow mesenchymal stem cell ameliorates the autoimmune pathogenesis in MRL/lpr mice. Cellular \& molecular immunology $\mathbf{5}$, 417-424

90. Gerdoni, E., Gallo, B., Casazza, S., Musio, S., Bonanni, I., Pedemonte, E., Mantegazza, R., Frassoni, F., Mancardi, G., Pedotti, R., and Uccelli, A. (2007) Mesenchymal stem cells effectively modulate pathogenic immune response in experimental autoimmune encephalomyelitis. Annals of neurology 61, 219-227

91. English, K., Barry, F. P., Field-Corbett, C. P., and Mahon, B. P. (2007) IFN-gamma and TNF-alpha differentially regulate immunomodulation by murine mesenchymal stem cells. Immunology letters 110, 91-100

92. Di Nicola, M., Carlo-Stella, C., Magni, M., Milanesi, M., Longoni, P. D., Matteucci, P., Grisanti, S., and Gianni, A. M. (2002) Human bone marrow stromal cells suppress T-lymphocyte proliferation induced by cellular or nonspecific mitogenic stimuli. Blood 99, 3838-3843

93. Aggarwal, S., and Pittenger, M. F. (2005) Human mesenchymal stem cells modulate allogeneic immune cell responses. Blood 105, 1815-1822

94. Qu, X., Liu, X., Cheng, K., Yang, R., and Zhao, R. C. (2012) Mesenchymal stem cells inhibit Th17 cell differentiation by IL-10 secretion. Experimental hematology 40, 761-770

95. Urban, V. S., Kiss, J., Kovacs, J., Gocza, E., Vas, V., Monostori, E., and Uher, F. (2008) Mesenchymal stem cells cooperate with bone marrow cells in therapy of diabetes. Stem cells (Dayton, Ohio) 26, 244-253

96. Li, M. O., Wan, Y. Y., Sanjabi, S., Robertson, A. K., and Flavell, R. A. (2006) Transforming growth factor-beta regulation of immune responses. Annual review of immunology 24, 99-146 
97. Kuroiwa, T., Kakishita, E., Hamano, T., Kataoka, Y., Seto, Y., Iwata, N., Kaneda, Y., Matsumoto, K., Nakamura, T., Ueki, T., Fujimoto, J., and Iwasaki, T. (2001) Hepatocyte growth factor ameliorates acute graft-versus-host disease and promotes hematopoietic function. The Journal of clinical investigation 107, 1365-1373

98. Le Blanc, K., Tammik, C., Rosendahl, K., Zetterberg, E., and Ringden, O. (2003) HLA expression and immunologic properties of differentiated and undifferentiated mesenchymal stem cells. Experimental hematology 31, 890-896

99. Ren, G., Su, J., Zhang, L., Zhao, X., Ling, W., L'Huillie, A., Zhang, J., Lu, Y., Roberts, A. I., Ji, W., Zhang, H., Rabson, A. B., and Shi, Y. (2009) Species variation in the mechanisms of mesenchymal stem cell-mediated immunosuppression. Stem cells (Dayton, Ohio) 27, 1954-1962

100. Le Friec, G., Laupeze, B., Fardel, O., Sebti, Y., Pangault, C., Guilloux, V., Beauplet, A., Fauchet, R., and Amiot, L. (2003) Soluble HLA-G inhibits human dendritic cell-triggered allogeneic T-cell proliferation without altering dendritic differentiation and maturation processes. Human immunology 64, 752-761

101. Selmani, Z., Naji, A., Zidi, I., Favier, B., Gaiffe, E., Obert, L., Borg, C., Saas, P., Tiberghien, P., Rouas-Freiss, N., Carosella, E. D., and Deschaseaux, F. (2008) Human leukocyte antigen-G5 secretion by human mesenchymal stem cells is required to suppress $\mathrm{T}$ lymphocyte and natural killer function and to induce CD4+CD25highFOXP3+ regulatory T cells. Stem cells (Dayton, Ohio) 26, 212-222

102. Rizzo, R., Campioni, D., Stignani, M., Melchiorri, L., Bagnara, G. P., Bonsi, L., Alviano, F., Lanzoni, G., Moretti, S., Cuneo, A., Lanza, F., and Baricordi, O. R. (2008) A functional role for soluble HLA-G antigens in immune modulation mediated by mesenchymal stromal cells. Cytotherapy 10, 364-375

103. Nasef, A., Mathieu, N., Chapel, A., Frick, J., Francois, S., Mazurier, C., Boutarfa, A., Bouchet, S., Gorin, N. C., Thierry, D., and Fouillard, L. (2007) Immunosuppressive effects of mesenchymal stem cells: involvement of HLA-G. Transplantation 84, 231-237

104. Sreeramkumar, V., Fresno, M., and Cuesta, N. (2012) Prostaglandin E2 and T cells: friends or foes? Immunology and cell biology 90, 579-586

105. Rasmusson, I., Ringden, O., Sundberg, B., and Le Blanc, K. (2005) Mesenchymal stem cells inhibit lymphocyte proliferation by mitogens and alloantigens by different mechanisms. Experimental cell research 305, 33-41

106. Ryan, J. M., Barry, F., Murphy, J. M., and Mahon, B. P. (2007) Interferon-gamma does not break, but promotes the immunosuppressive capacity of adult human mesenchymal stem cells. Clinical and experimental immunology 149, 353-363

107. Cuerquis, J., Romieu-Mourez, R., Francois, M., Routy, J. P., Young, Y. K., Zhao, J., and Eliopoulos, N. (2014) Human mesenchymal stromal cells transiently increase cytokine production by activated $\mathrm{T}$ cells before suppressing $\mathrm{T}$-cell proliferation: effect of interferon-gamma and tumor necrosis factor-alpha stimulation. Cytotherapy 16, 191-202

108. Saraiva, M., and O'Garra, A. (2010) The regulation of IL-10 production by immune cells. Nature reviews. Immunology 10, 170-181

109. Moffett, J. R., and Namboodiri, M. A. (2003) Tryptophan and the immune response. Immunology and cell biology 81, 247-265

110. Meisel, R., Zibert, A., Laryea, M., Gobel, U., Daubener, W., and Dilloo, D. (2004) Human bone marrow stromal cells inhibit allogeneic T-cell responses by indoleamine 2,3-dioxygenase-mediated tryptophan degradation. Blood 103, 46194621 
111. Francois, M., Romieu-Mourez, R., Li, M., and Galipeau, J. (2012) Human MSC suppression correlates with cytokine induction of indoleamine 2,3-dioxygenase and bystander M2 macrophage differentiation. Molecular therapy: the journal of the American Society of Gene Therapy 20, 187-195

112. Su, J., Chen, X., Huang, Y., Li, W., Li, J., Cao, K., Cao, G., Zhang, L., Li, F., Roberts, A. I., Kang, H., Yu, P., Ren, G., Ji, W., Wang, Y., and Shi, Y. (2014) Phylogenetic distinction of iNOS and IDO function in mesenchymal stem cellmediated immunosuppression in mammalian species. Cell Death Differ 21, 388396

113. Xu, G., Zhang, L., Ren, G., Yuan, Z., Zhang, Y., Zhao, R. C., and Shi, Y. (2007) Immunosuppressive properties of cloned bone marrow mesenchymal stem cells. Cell research 17, 240-248

114. Sato, K., Ozaki, K., Oh, I., Meguro, A., Hatanaka, K., Nagai, T., Muroi, K., and Ozawa, K. (2007) Nitric oxide plays a critical role in suppression of T-cell proliferation by mesenchymal stem cells. Blood 109, 228-234

115. Ren, G., Zhang, L., Zhao, X., Xu, G., Zhang, Y., Roberts, A. I., Zhao, R. C., and Shi, Y. (2008) Mesenchymal stem cell-mediated immunosuppression occurs via concerted action of chemokines and nitric oxide. Cell stem cell 2, 141-150

116. Djouad, F., Charbonnier, L. M., Bouffi, C., Louis-Plence, P., Bony, C., Apparailly, F., Cantos, C., Jorgensen, C., and Noel, D. (2007) Mesenchymal stem cells inhibit the differentiation of dendritic cells through an interleukin-6-dependent mechanism. Stem cells (Dayton, Ohio) 25, 2025-2032

117. Keir, M. E., Butte, M. J., Freeman, G. J., and Sharpe, A. H. (2008) PD-1 and its ligands in tolerance and immunity. Annual review of immunology 26, 677-704

118. Augello, A., Tasso, R., Negrini, S. M., Cancedda, R., and Pennesi, G. (2007) Cell therapy using allogeneic bone marrow mesenchymal stem cells prevents tissue damage in collagen-induced arthritis. Arthritis and rheumatism 56, 1175-1186

119. Sheng, H., Wang, Y., Jin, Y., Zhang, Q., Zhang, Y., Wang, L., Shen, B., Yin, S., Liu, W., Cui, L., and Li, N. (2008) A critical role of IFNgamma in priming MSCmediated suppression of $\mathrm{T}$ cell proliferation through up-regulation of B7-H1. Cell research 18, 846-857

120. Scheller, J., Chalaris, A., Schmidt-Arras, D., and Rose-John, S. (2011) The proand anti-inflammatory properties of the cytokine interleukin-6. Biochimica et biophysica acta 1813, 878-888

121. Bouffi, C., Bony, C., Courties, G., Jorgensen, C., and Noel, D. (2010) IL-6dependent PGE2 secretion by mesenchymal stem cells inhibits local inflammation in experimental arthritis. PLoS One 5, e14247

122. Korhonen, R., Lahti, A., Kankaanranta, H., and Moilanen, E. (2005) Nitric oxide production and signaling in inflammation. Current drug targets. Inflammation and allergy 4, 471-479

123. Tayeh, M. A., and Marletta, M. A. (1989) Macrophage oxidation of L-arginine to nitric oxide, nitrite, and nitrate. Tetrahydrobiopterin is required as a cofactor. The Journal of biological chemistry 264, 19654-19658

124. Schneemann, M., and Schoeden, G. (2007) Macrophage biology and immunology: man is not a mouse. Journal of leukocyte biology 81, 579; discussion 580

125. Meisel, R., Brockers, S., Heseler, K., Degistirici, O., Bulle, H., Woite, C., Stuhlsatz, S., Schwippert, W., Jager, M., Sorg, R., Henschler, R., Seissler, J., Dilloo, D., and Daubener, W. (2011) Human but not murine multipotent 
mesenchymal stromal cells exhibit broad-spectrum antimicrobial effector function mediated by indoleamine 2,3-dioxygenase. Leukemia 25, 648-654

126. O'Shea, J. J., Ma, A., and Lipsky, P. (2002) Cytokines and autoimmunity. Nature reviews. Immunology 2, 37-45

127. Shi, Y., Hu, G., Su, J., Li, W., Chen, Q., Shou, P., Xu, C., Chen, X., Huang, Y., Zhu, Z., Huang, X., Han, X., Xie, N., and Ren, G. (2010) Mesenchymal stem cells: a new strategy for immunosuppression and tissue repair. Cell research 20, 510-518

128. Krampera, M. (2011) Mesenchymal stromal cell 'licensing': a multistep process. Leukemia 25, 1408-1414

129. Gilbert, L. C., Rubin, J., and Nanes, M. S. (2005) The p55 TNF receptor mediates TNF inhibition of osteoblast differentiation independently of apoptosis. American journal of physiology. Endocrinology and metabolism 288, E1011-1018

130. Lacey, D. C., Simmons, P. J., Graves, S. E., and Hamilton, J. A. (2009) Proinflammatory cytokines inhibit osteogenic differentiation from stem cells: implications for bone repair during inflammation. Osteoarthritis and cartilage / OARS, Osteoarthritis Research Society 17, 735-742

131. Liu, Y., Wang, L., Kikuiri, T., Akiyama, K., Chen, C., Xu, X., Yang, R., Chen, W., Wang, S., and Shi, S. (2011) Mesenchymal stem cell-based tissue regeneration is governed by recipient $\mathrm{T}$ lymphocytes via IFN-gamma and TNF-alpha. Nature medicine 17, 1594-1601

132. Yang, N., Wang, G., Hu, C., Shi, Y., Liao, L., Shi, S., Cai, Y., Cheng, S., Wang, X., Liu, Y., Tang, L., Ding, Y., and Jin, Y. (2013) Tumor necrosis factor alpha suppresses the mesenchymal stem cell osteogenesis promoter miR-21 in estrogen deficiency-induced osteoporosis. Journal of bone and mineral research : the official journal of the American Society for Bone and Mineral Research 28, 559573

133. Hess, K., Ushmorov, A., Fiedler, J., Brenner, R. E., and Wirth, T. (2009) TNFalpha promotes osteogenic differentiation of human mesenchymal stem cells by triggering the NF-kappaB signaling pathway. Bone 45, 367-376

134. Osta, B., Lavocat, F., Eljaafari, A., and Miossec, P. (2014) Effects of Interleukin17A on Osteogenic Differentiation of Isolated Human Mesenchymal Stem Cells. Front Immunol 5, 425

135. Huang, H., Zhao, N., Xu, X., Xu, Y., Li, S., Zhang, J., and Yang, P. (2011) Dosespecific effects of tumor necrosis factor alpha on osteogenic differentiation of mesenchymal stem cells. Cell proliferation 44, 420-427

136. Suzawa, M., Takada, I., Yanagisawa, J., Ohtake, F., Ogawa, S., Yamauchi, T., Kadowaki, T., Takeuchi, Y., Shibuya, H., Gotoh, Y., Matsumoto, K., and Kato, S. (2003) Cytokines suppress adipogenesis and PPAR-gamma function through the TAK1/TAB1/NIK cascade. Nature cell biology 5, 224-230

137. Liu, Y., Han, Z. P., Zhang, S. S., Jing, Y. Y., Bu, X. X., Wang, C. Y., Sun, K., Jiang, G. C., Zhao, X., Li, R., Gao, L., Zhao, Q. D., Wu, M. C., and Wei, L. X. (2011) Effects of inflammatory factors on mesenchymal stem cells and their role in the promotion of tumor angiogenesis in colon cancer. The Journal of biological chemistry 286, 25007-25015

138. Liotta, F., Angeli, R., Cosmi, L., Fili, L., Manuelli, C., Frosali, F., Mazzinghi, B., Maggi, L., Pasini, A., Lisi, V., Santarlasci, V., Consoloni, L., Angelotti, M. L., Romagnani, P., Parronchi, P., Krampera, M., Maggi, E., Romagnani, S., and Annunziato, F. (2008) Toll-like receptors 3 and 4 are expressed by human bone 
marrow-derived mesenchymal stem cells and can inhibit their T-cell modulatory activity by impairing Notch signaling. Stem cells (Dayton, Ohio) 26, 279-289

139. Romieu-Mourez, R., Francois, M., Boivin, M. N., Bouchentouf, M., Spaner, D. E., and Galipeau, J. (2009) Cytokine modulation of TLR expression and activation in mesenchymal stromal cells leads to a proinflammatory phenotype. Journal of immunology (Baltimore, Md. : 1950) 182, 7963-7973

140. Tisato, V., Naresh, K., Girdlestone, J., Navarrete, C., and Dazzi, F. (2007) Mesenchymal stem cells of cord blood origin are effective at preventing but not treating graft-versus-host disease. Leukemia 21, 1992-1999

141. Yanez, R., Lamana, M. L., Garcia-Castro, J., Colmenero, I., Ramirez, M., and Bueren, J. A. (2006) Adipose tissue-derived mesenchymal stem cells have in vivo immunosuppressive properties applicable for the control of the graft-versus-host disease. Stem cells (Dayton, Ohio) 24, 2582-2591

142. Zappia, E., Casazza, S., Pedemonte, E., Benvenuto, F., Bonanni, I., Gerdoni, E., Giunti, D., Ceravolo, A., Cazzanti, F., Frassoni, F., Mancardi, G., and Uccelli, A. (2005) Mesenchymal stem cells ameliorate experimental autoimmune encephalomyelitis inducing T-cell anergy. Blood 106, 1755-1761

143. Polchert, D., Sobinsky, J., Douglas, G. W., Kidd, M., Moadsiri, A., Reina, E., Genrich, K., Mehrotra, S., Setty, S., Smith, B., and Bartholomew, A. (2008) IFN- $\gamma$ activation of mesenchymal stem cells for treatment and prevention of graft versus host disease. European journal of immunology 38, 1745-1755

144. Krampera, M., Cosmi, L., Angeli, R., Pasini, A., Liotta, F., Andreini, A., Santarlasci, V., Mazzinghi, B., Pizzolo, G., Vinante, F., Romagnani, P., Maggi, E., Romagnani, S., and Annunziato, F. (2006) Role for interferon-gamma in the immunomodulatory activity of human bone marrow mesenchymal stem cells. Stem cells (Dayton, Ohio) 24, 386-398

145. Hemeda, H., Jakob, M., Ludwig, A. K., Giebel, B., Lang, S., and Brandau, S. (2010) Interferon-gamma and tumor necrosis factor-alpha differentially affect cytokine expression and migration properties of mesenchymal stem cells. Stem cells and development 19, 693-706

146. Pevsner-Fischer, M., Levin, S., and Zipori, D. (2011) The origins of mesenchymal stromal cell heterogeneity. Stem cell reviews 7, 560-568

147. Phinney, D. G., Kopen, G., Righter, W., Webster, S., Tremain, N., and Prockop, D. J. (1999) Donor variation in the growth properties and osteogenic potential of human marrow stromal cells. Journal of cellular biochemistry 75, 424-436

148. Pittenger, M. F., Mackay, A. M., Beck, S. C., Jaiswal, R. K., Douglas, R., Mosca, J. D., Moorman, M. A., Simonetti, D. W., Craig, S., and Marshak, D. R. (1999) Multilineage potential of adult human mesenchymal stem cells. Science (New York, N.Y.) 284, 143-147

149. Muraglia, A., Cancedda, R., and Quarto, R. (2000) Clonal mesenchymal progenitors from human bone marrow differentiate in vitro according to a hierarchical model. Journal of cell science 113 ( Pt 7), 1161-1166

150. Russell, K. C., Lacey, M. R., Gilliam, J. K., Tucker, H. A., Phinney, D. G., and O'Connor, K. C. (2011) Clonal analysis of the proliferation potential of human bone marrow mesenchymal stem cells as a function of potency. Biotechnology and bioengineering 108, 2716-2726

151. Okamoto, T., Aoyama, T., Nakayama, T., Nakamata, T., Hosaka, T., Nishijo, K., Nakamura, T., Kiyono, T., and Toguchida, J. (2002) Clonal heterogeneity in 
differentiation potential of immortalized human mesenchymal stem cells. Biochem Biophys Res Commun 295, 354-361

152. Guilak, F., Lott, K. E., Awad, H. A., Cao, Q., Hicok, K. C., Fermor, B., and Gimble, J. M. (2006) Clonal analysis of the differentiation potential of human adipose-derived adult stem cells. Journal of cellular physiology 206, 229-237

153. Lei, J., Hui, D., Huang, W., Liao, Y., Yang, L., Liu, L., Zhang, Q., Qi, G., Song, W., Zhang, Y., Xiang, A. P., and Zhou, Q. (2013) Heterogeneity of the biological properties and gene expression profiles of murine bone marrow stromal cells. The international journal of biochemistry \& cell biology 45, 2431-2443

154. Jeon, M. S., Yi, T. G., Lim, H. J., Moon, S. H., Lee, M. H., Kang, J. S., Kim, C. S., Lee, D. H., and Song, S. U. (2011) Characterization of mouse clonal mesenchymal stem cell lines established by subfractionation culturing method. World journal of stem cells 3, 70-82

155. Garlanda, C., Parravicini, C., Sironi, M., De Rossi, M., Wainstok de Calmanovici, R., Carozzi, F., Bussolino, F., Colotta, F., Mantovani, A., and Vecchi, A. (1994) Progressive growth in immunodeficient mice and host cell recruitment by mouse endothelial cells transformed by polyoma middle-sized $\mathrm{T}$ antigen: implications for the pathogenesis of opportunistic vascular tumors. Proceedings of the National Academy of Sciences of the United States of America 91, 7291-7295

156. Gyorfy, Z., Benko, S., Kusz, E., Maresca, B., Vigh, L., and Duda, E. (1997) Highly Increased TNF Sensitivity of Tumor Cells Expressing the Yeast $\Delta 9$-Desaturase Gene. Biochemical and Biophysical Research Communications 241, 465-470

157. Phinney, D. G. (2012) Functional heterogeneity of mesenchymal stem cells: implications for cell therapy. Journal of cellular biochemistry 113, 2806-2812

158. Levin, S., Pevsner-Fischer, M., Kagan, S., Lifshitz, H., Weinstock, A., Gataulin, D., Friedlander, G., and Zipori, D. (2014) Divergent levels of LBP and TGFbeta1 in murine MSCs lead to heterogenic response to TLR and proinflammatory cytokine activation. Stem cell reviews 10, 376-388

159. Chen, L., Tredget, E. E., Wu, P. Y. G., and Wu, Y. (2008) Paracrine Factors of Mesenchymal Stem Cells Recruit Macrophages and Endothelial Lineage Cells and Enhance Wound Healing. PLoS ONE 3, e1886

160. Kleinert, H., Schwarz, P. M., and Forstermann, U. (2003) Regulation of the expression of inducible nitric oxide synthase. Biological chemistry 384, 1343-1364

161. Soderberg, M., Raffalli-Mathieu, F., and Lang, M. A. (2007) Identification of a regulatory cis-element within the 3'-untranslated region of the murine inducible nitric oxide synthase (iNOS) mRNA; interaction with heterogeneous nuclear ribonucleoproteins $\mathrm{I}$ and $\mathrm{L}$ and role in the iNOS gene expression. Molecular immunology 44, 434-442

162. Hucke, C., MacKenzie, C. R., Adjogble, K. D., Takikawa, O., and Daubener, W. (2004) Nitric oxide-mediated regulation of gamma interferon-induced bacteriostasis: inhibition and degradation of human indoleamine 2,3-dioxygenase. Infection and immunity 72, 2723-2730 


\section{Saját közlemények}

\section{Az értekezéshez kapcsolódó folyóirat cikkek:}

1) Szabó, E., Fajka-Boja, R., Kriston-Pál, É., Hornung, Á., Makra, I., Kudlik, G., Uher, F., Katona, R. L., Monostori, É. and Czibula, Á. (2015) Licensing by Inflammatory Cytokines Abolishes Heterogeneity of Immunosuppressive Function of Mesenchymal Stem Cell Population. Stem Cells and Development 24, 21712180. IF(2014): 3.727

2) Szebeni, G. J., Kriston-Pál, É., Blazsó, P., Katona, R. L., Novák, J., Szabó, E., Czibula, Á., Fajka-Boja, R., Hegyi, B., Uher, F., Krenács, L., Joó, G., and Monostori, É. (2012) Identification of Galectin-1 as a Critical Factor in Function of Mouse Mesenchymal Stromal Cell-Mediated Tumor Promotion. PLoS ONE 7, e41372. IF(2012): 3.730

\section{Egyéb folyóirat cikkek:}

1) Deák, M., Hornung, Á., Novák, J., Demydenko, D., Szabó, E., Czibula, Á., FajkaBoja, R., Kriston-Pál, É., Monostori, É. and Kovács, L. (2014) Novel role for galectin-1 in T-cells under physiological and pathological conditions. Immunobiology 220, 483-489. IF(2014): 3.044

\section{Összes IF: 10.501}

\section{Idézhető absztraktok:}

1. Hornung, Á., Deák, M., Novák, J., Szabó, E., Czibula, Á., Fajka-Boja, R., KristonPál, É., Monostori, É. and Kovács, L. (2015) Novel role for galectin-1 in T-cell apoptosis regulation and its relevance to systemic lupus erythematosus. Annals of the Rheumatic Diseases 74, A19 doi:10.1136/annrheumdis-2015-207259.44

\section{Konferencia előadások:}

1. Szabó Enikő. „Csontvelöi eredetü mesenchymális össejtek heterogenitásának és differenciálódási tulajdonságainak vizsgálata az MSC sejtpopuláció klónozásával és nem-specifikus RNS interferencia alkalmazásával”. 2010. évi őszi Tudományos Diákköri Konferencia. Szeged, 2010. november 18.

2. Szabó Enikő. „Csontvelői eredetü mesenchymális össejtek heterogenitásának és differenciálódási tulajdonságainak vizsgálata az MSC sejtpopuláció klónozásával és nem-specifikus RNS interferencia alkalmazásával". XXX. Jubileumi Országos Tudományos Diákköri Konferencia. Budapest, 2011. április 19-21.

3. Szebeni Gábor János, Kriston-Pál Éva, Blazsó Péter, Katona Róbert, Novák Julianna, Szabó Enikő, Joó Gabriella, Hegyi Beáta, Uher Ferenc, Krenács László,Fajka-Boja Roberta, Czibula Ágnes, Monostori Éva „Identification of galectin-1 as a critical factor in function of mesenchymal stem cell-mediated tumour promotion", Instituto Clinico Humanitas, Milanó, 2011. december 02. 
4. Szebeni Gábor János, Kriston-Pál Éva, Blazsó Péter, Katona Róbert, Novák Julianna, Szabó Enikő, Joó Gabriella, Hegyi Beáta, Uher Ferenc, Krenács László,Fajka-Boja Roberta, Czibula Ágnes, Monostori Éva „A galektin-1, mint a mesenchymalis össejtek tumorfejllödésre gyakorolt hatásában azonositott új faktor." Magyar Immunológiai Társaság 40. Vándorgyülése, Kecskemét, 2011. október 12-14.

5. Kriston-Pál Éva, Szebeni Gábor János, Novák Julianna, Czibula Ágnes, Szabó Enikő, Fajka-Boja Roberta, Uher Ferenc, Krenács László, Monostori Éva „A mesenchymalis össejtek által termelt galektin-1 az érképzödés serkentésével befolyásolja a tumorfejlödést”. Magyar Immunológiai Társaság 41. Vándorgyülése, Debrecen, 2012. október 17-19.

6. Szabó Enikő, Czibula Ágnes, Fajka-Boja Roberta, Kriston-Pál Éva, Uher Ferenc, Kudlik Gyöngyi, Katona Róbert, Monostori Éva „Az egér csontvelöi mesenchymalis össejtek heterogenitása differenciálódás és immunszuppresszió szempontjából' 15. Kolozsvári Biológus Napok, Kolozsvár, 2014. április 4-6.

7. Szabó Enikö, „Az egér csontvelöi mesenchymalis össejtek heterogenitása differenciálódás és immunszuppresszió szempontjából". Szegedi Biológus Doktorandusz Konferencia 2014, Szeged, 2014. május 19-20.

8. Szabó Enikő, Fajka-Boja Roberta, Kriston-Pá Éva, Hornung Ákos, Makra Ildikó, Kudlik Gyöngyi, Uher Ferenc, Katona Róbert László, Monostori Éva, Czibula Ágnes „Licensing by inflammatory cytokines abolishes heterogeneity of immunosuppressive function of mesenchymal stem cell population”. Molekuláris Élettudományi Konferencia (Hungarian Molecular Life Sciences Conference), Eger, 2015. március 27-29.

\section{Konferencia poszterek:}

1. Szabó Enikő, Czibula Ágnes, Blazsó Péter, Katona Róbert, Uher Ferenc, Monostori Éva. „Csontvelöi eredető mesenchymalis össejtek klónozása az MSC sejtpopuláció heterogenitásának vizsgálatához”. Magyar Immunológiai Társaság 39. Vándorgyülése, Szeged, 2010. november 3-5.

2. Szabó Enikő, Czibula Ágnes, Blazsó Péter, Katona Róbert, Uher Ferenc, Monostori Éva. „Csontvelői eredetü mesenchymalis őssejtek heterogenitásának és differenciálódási tulajdonságainak vizsgálata". IX. Magyar Genetikai Kongresszus és XVI. Sejt- és Fejlődésbiológiai Napok, Siófok, 2011. március 25.-27.

3. Szabó Enikő, Czibula Ágnes, Blazsó Péter, Katona Róbert, Uher Ferenc, Monostori Éva „Csontvelöi eredetü mesenchymalis össejt populáció heterogenitásának vizsgálata monoklonális sejtvonalak létrehozásával”. Magyar Immunológiai Társaság 40. Vándorgyülése, Kecskemét, 2011. október 12-14.

4. Kriston-Pál Éva, Szebeni Gábor János, Novák Julianna, Fajka-Boja Roberta, Szabó Enikő, Czibula Ágnes, Uher Ferenc, Monostori Éva. "Identification of galectin-1 as a critical factor in function of mouse mesenchymal stem cell-mediated tumor promotion". EMBL Conference Stem Cells in Cancer and Regenerative Medicine, Heidelberg, 2012. augusztus 29. 


\section{IX. Összefoglalás}

A mesenchymalis őssejtek (MSC) multipotens felnőtt szöveti őssejtek. Megfelelö induktív környezetben mezodermális irányba differenciálódva zsír-, csont- és porcsejtekké alakulnak. Differenciálódási képességük és biológiailag aktív faktorok által kifejtett immunszuppresszív hatásuk miatt a regeneratív és immunszuppresszív medicina egyik fontos eszközei lehetnek. Így az MSC-k segítik a sérülést, szövetpusztulást követő szövetmegújulást, érképződést, illetve mérsékelhetik a sérülés helyén kialakuló gyulladásos immunválaszt. A humán orvoslásban betöltött szerepe miatt az MSC heterogenitás megismerése fontos teendő. A heterogenitás különböző szinteken vizsgálható és vizsgálandó: 1) a különböző egyedekből izolált MSC populációk eltérőek; 2) adott egyed különböző szöveteiből kivont MSC-k morfológiailag, növekedési és differenciálódási képességüket tekintve eltérőek; 3) Adott egyed adott szövetéből izolált MSC egyes sejtjei szintén eltérőek lehetnek (klonális heterogenitás). Munkánk során az egér csontvelői MSC populáció egyedi sejtjeinek klonális különbségeit vizsgáltuk.

Ebből a célból egér csontvelői MSC kultúrából hígításos módszerrel egy sejt eredetü klónokat izoláltunk, és ezek közül öt (MSC2-6) klón tulajdonságait hasonlítottuk össze különböző szempontok alapján. A vizsgált MSC klónok morfológiája, osztódási képessége hasonló, és az MSC kritériumoknak megfelelő sejtfelszíni markerprofillal rendelkeznek: CD45, $\mathrm{CD} 11 \mathrm{~b}-\mathrm{CD} 29^{+}, \mathrm{CD} 44^{+}, \mathrm{CD}^{-} 3^{+}, \mathrm{CD} 106^{+}, \mathrm{CD} 119^{+}$és Sca- $1^{+}$. Specifikus faktorok jelenlétében csontképző sejt és zsírsejt irányba differenciálódnak. A hisztokémiai festések alapján az MSC2, MSC4 és MSC5 klónok erőteljesebben, míg az MSC3 és MSC6 klónok gyengébben differenciálódnak csontképző sejt irányba. A klónok zsírsejt irányú differenciációja hasonló mértékü, amit a lipidtartalom meghatározására alkalmas áramlási citometriás méréssel igazoltunk. In vitro angiogenezis modellben az MSC klónok endotélsejtekkel együtt tenyésztve prevascularis struktúrákat képeznek. A struktúrák hossza és a klónok proangiogén faktor (ér-endotél növekedési faktor, angiopoietin-1, galektin-1) mRNS kifejeződése mindegyik klón esetében hasonló.

Az MSC klónok immunszabályozó tulajdonságát in vitro és in vivo modellrendszerben vizsgáltuk. Az in vitro MSC-T-sejt kokultúra rendszerben mindegyik klón szignifikánsan gátolja a nyirokcsomóból izolált, aktivált T-sejtek osztódását, de a gátlás mértéke a különböző klónok között nagy különbségeket mutat. Az MSC2, MSC4 és MSC5 erősen, az MSC3 és MSC6 gyengén gátolja a T-sejtek osztódását, tehát a klónok 
gátlóképesség szerint a következő sorrendbe állíthatóak: MSC2 $\geq$ MSC5 > MSC4 > MSC3 >> MSC6. E különbség okának feltárására meghatároztuk az MSC klónok immunszuppresszióért felelős faktorait kódoló gének expresszióját kvantitatív valós idejü PCR-rel (qRT-PCR). A prosztaglandin-endoperoxid szintáz 2-t kódoló gén (Ptgs2) mindegyik klónban magasan fejeződik ki, az indolamin-2,3dioxigenáz 1-et kódoló gén (Idol) kifejeződése pedig egyik klónban sem mutatható ki. Jelentős a különbség a nitrogén-monoxid (NO) szintáz 2 (Nos2) génexpressziójában: az erősen gátló MSC2, MSC4 és MSC5 klónban magasan, a gyengén gátló MSC3 klónban alacsonyan, a leggyengébben gátló MSC6 klónban pedig egyáltalán nem fejeződik ki. Ezek az eredmények azt jelzik, hogy a NO a T-sejt proliferáció gátlásában alapvető szerepet játszik. A NO szerepének igazolására az MSC2 és MSC6 klónt vizsgáltuk, specifikus NOS2 gátlószert, az L-NMMA-t alkalmazva. A NOS2 inhibítor teljes mértékben gátolta az erősen gátló, nagy mennyiségü Nos 2 mRNS-t expresszáló MSC2, míg nem befolyásolta a gyengén gátló, Nos2-t nem expresszáló MSC6 T-sejt proliferáció gátló hatását. A PGE2 termelés és az IDO1 enzimaktivitás gátlása alapján a PGE2 szerepe részleges az MSC2, míg nem befolyásolja az MSC6 T-sejt osztódás gátlását.

Az MSC klónok in vivo immunmoduláló képességének tanulmányozására ovalbuminnal egerekben kiváltott késői típusú túlérzékenységi reakciót (DTH) alkalmaztunk. Az in vivo modell alátámasztja és igazolja az in vitro rendszerben kapott eredményeket, mivel a T-sejt proliferáció gátlásában leghatékonyabb MSC2 szignifikánsan gátolja a DTH reakciót, míg a legkevésbé gátló MSC6 klón nem befolyásolja az ovalbuminnal kiváltott túlérzékenységi választ.

Az MSC-k differenciálódási és gyulladáscsökkentő képességét igyekeznek kiaknázni az egyre sokoldalúbb sejtterápiás felhasználás során. Az MSC terápia legígéretesebb területei a csontvelő átültetés után gyakran súlyos tünetekkel fellépő immunológiai kórkép, a graft-versus-host betegség kezelése, illetve a regeneratív medicina. A terápia során a szervezetbe oltott MSC-k gyakran gyulladásos környezetbe jutnak, ahol gyulladásos citokinek (IFN- $\gamma$ és TNF- $\alpha$ ) befolyásolhatják az MSC-k funkcionális tulajdonságait.

Az IFN- $\gamma$-val és TNF- $\alpha$-val történő előkezelés gátolja az MSC-k csont irányú differenciálódását és a folyamatot jelző gének (Runx2, Bglap, Spp1) kifejeződését. A gyulladáskeltő citokinek az MSC klónok proangiogén tulajdonságát is megszüntetik, mivel 
az in vitro MSC-endotélsejt kokultúrákban IFN- $\gamma$ és TNF- $\alpha$ jelenlétében a prevascularis struktúrák nem alakulnak ki.

Az MSC klónok immunszuppresszív hatásának vizsgálata során az eredmények azt támasztották alá, hogy az IFN- $\gamma$-val és TNF- $\alpha$-val történő előkezelés serkenti az MSC klónok T-sejt osztódásgátló aktivitását. A gátlóképesség fokozódása a gyengén gátló MSC3 és MSC6 klónokban a legkifejezettebb. Ezzel összhangban az IFN- $\gamma$ és TNF- $\alpha$ kezelés indukálja az immunszuppresszióért felelős faktorokat kódoló gének (Nos2, Ptgs2, Ido1) kifejeződését. Az immunszuppresszív faktorok szerepét a T-sejt proliferáció gátlásban specifikus gátlószerek segítségével igazoltuk, hasonlóan, mint a nem stimulált klónok esetében. A NOS2 enzim inhibítora, az L-NMMA blokkolja az MSC2 és MSC6 (melyek gátló hatása hasonlóvá válik a citokin előkezelés után) T-sejt proliferáció gátlását, alátámasztva a NO szerepét. A PGE2 termelés gátlása indometacinnal a PGE2 részleges szerepét igazolja, míg az IDO1 inhibítorának, az 1-metil-triptofánnak a jelenléte nem befolyásolja az MSC klónok aktivitását kizárva ennek a faktornak a közremüködését.

$\mathrm{Az}$ in vitro adatokat az in vivo eredmények is alátámasztják. A gyulladásos citokinekkel történő elökezelés megszünteti a stimulálatlan MSC2 és MSC6 klónok között tapasztalt különbséget, mivel az előkezelés hatására az MSC2 és MSC6 hasonlóan gátolja a DTH reakciót.

Eredményeink összefoglalása: a csontvelői MSC populáció funkcionálisan heterogén, ami a csont irányú differenciálódásban és még erőteljesebben az immunválasz gátlásában érvényesül. A gyulladásos környezetben jelenlevő citokinek, az IFN- $\gamma$ és TNFa polarizálják az MSC-k funkcióit azáltal, hogy csökken a differenciálódási képességük és angiogenezisben betöltött szerepük, míg jelentősen megnő az immunszuppresszív aktivitásuk. Ezért érdemes lehet megfontolni ennek a vizsgálatnak az eredményeit az immunológiai és regeneratív terápiás felhasználást megelőzően, vagyis az immunológiai felhasználás során az MSC-k gyulladásos citokinekkel való előkezelését, regeneratív terápiában a terápiát megelőző gyulladás csökkentést. 


\section{Summary}

Mesenchymal stem cells (MSCs) are resident in many adult tissues. These cells are capable to differentiate into mesodermal lineages such as adipocytes, osteoblasts and chondrocytes, moreover they produce a plethora of bioactive molecules. Due to their differentiation into various cell types, production of a plethora of soluble factors including those with immunoregulatory functions and pro-angionic activity, MSCs have been implicated in medical applications such as regenerative medicine and treating immunological disorders. Hence the importance of mastery of heterogeneity of MSC population has emerged. Different levels of heterogeneity could be and has to be investigated: 1) MSCs from different individuals can be distinguished; 2) MSCs from various tissues of one individual are different regarding the cell morphology, growth and differentiation abilities; 3) MSCs from a given tissue of one animal may exert clonal heterogeneity. Our work aimed to examine the clonal heterogeneity of mouse bone marrow MSC.

To approach clonal heterogeneity, single cell MSC clones were generated from mouse bone marrow-derived MSC culture using limiting dilution cloning technique. The functional properties of five of these MSC clones (MSC2-MSC6) were further characterized. Morphology, proliferation rate of the MSC clones were similar and all clones were CD45 $, \mathrm{CD} 11 \mathrm{~b}^{-}, \mathrm{CD} 29^{+}, \mathrm{CD} 44^{+}, \mathrm{CD}_{3}{ }^{+}, \mathrm{CD} 106^{+}, \mathrm{CD} 119^{+}$and $\mathrm{Sca}-1^{+}$ fulfilling MSC criteria. In the presence of inducing factors, MSC clones differentiated in vitro into osteoblasts and adipocytes. Based on histochemical staining, MSC2, MSC4 and MSC5 exhibited strong, while MSC3 and MSC6 weak osteoblast differentiation. Cytofluorimetric lipid quantification showed similar lipid accumulation in MSC clones during adipogeneic differentiation. Pro-angiogenic effect of MSC clones was examined in an in vitro angiogenesis test where MSC clones pre-seeded with endothelial cells assembled into pre-vascular structures to a similar extent. Analysis of pro-angiogenic factor expression by qRT-PCR showed that all clones expressed similar level of angiopoietin-1 (Angpt1), vascular endothelial growth factor A (Vegfa) and galectin-1 mRNAs.

Immunomodulatory properties of MSC clones were assessed both in vitro and in vivo model systems. In in vitro MSC-T-cell co-culture experiments all MSC clones exhibited significant proliferation inhibition of ConA-activated T-cells. Nevertheless, the 
degree of inhibition remarkably differed between the clones. Hence, proliferation of Tcells was robustfully diminished in the presence of MSC2, MSC4, and MSC5 while it was poorly inhibited by MSC3 and MSC6 resulting in the following order: MSC2 $\geq$ MSC5 $>$ MSC4 $>$ MSC3 $>>$ MSC6. To explore the background of the clonal variability, the expression levels of genes encoding immunomodulatory factors or enzymes involved in factor synthesis have been determined using qRT-PCR. Prostaglandin endoperoxide synthase 2 (Ptgs2) mRNA was equally high in all clones while indolamine2,3-dioxygenase 1 (Idol) mRNA were not detected in either clones. Nevertheless, mRNA encoding nitric oxide (NO) synthase 2 (Nos2), an enzyme responsible for generation of anti-inflammatory mediator, NO showed substantial difference between the MSC clones: it was expressed at higher levels in MSC2, MSC5 and MSC4 than in MSC3 and was undetectable in MSC6 indicating a pivotal role of NO. To verify the essential role of NO in inhibition of T-cell proliferation, NOS2 activity was blocked by a specific inhibitor, LNMMA. This drug impeded the function of MSC2 and as it was expected, did not affect the non-inhibitory clone, MSC6 which did not expressed NOS2. Blocking PTGS2 with indometacin resulted in partial inhibition of MSC2 and no inhibition of anti-proliferative effect of MSC6.

To investigate in vivo immunomodulation, the effects of the most and least immunosuppressive MSC2 and MSC6 clones, respectively, were tested in ovalbumininduced delayed type hypersensitivity (DTH) response in mice. The results obtained in the in vivo model supported those of in vitro findings as MSC2 significantly prevented, while MSC6 did not affect the hypersensitivity response.

Cell therapies, incessantly increasing in number, represent a possibility to benefit from MSCs' property of differentiation, anti-inflammatory effect. Treatment of acute graft versus host disease, which is common but severe complication after allogeneic bone marrow transplantation, is one of the most promising targets of MSC therapies besides regenerative medicine e.g. in orthopedics. During application as cell therapy, MSCs frequently get into an inflammatory environment where inflammatory cytokines, such as IFN- $\gamma$ and TNF- $\alpha$ occur abundantly. Hence, it is of special interest how the inflammatory environment affects the MSC functions.

We have shown that pre-treatment of MSC clones with IFN- $\gamma$ and TNF- $\alpha$, a process, called "licensing", diminishes the osteoblast differentiation and accordingly the expression of specific marker genes (Runx2, Bglap, Spp1). In addition, pro-inflammatory 
cytokines abolished the pro-angiogenic function of MSC clones as well. Complete lack of pre-vascular structures was observed in co-cultures of MSC clones and endothelial cells.

Licensing by IFN- $\gamma$ and TNF- $\alpha$ enhanced the anti-proliferative activity of MSC clones in MSC-T-cell co-cultures. This effect was the most prominent in MSC3 and MSC6 clones, which exerted poor inhibitory activity without cytokine treatment. In good agreement with triggered proliferation inhibitory effect of the MSC clones, expression of Nos2, Ptgs2 and Ido1 involved in immunosuppression by MSCs were upregulated. Specific inhibitor of NOS2, L-NMMA blocked the immunosuppressive activity supporting the important role of NO. Inhibition of production of PGE2 with indometacin and activity of IDO1 with 1-MT resulted in partial and no retardation of anti-proliferative effect of MSC clones indicating a partial or no role of PGE2 and IDO1, respectively.

In vitro results were validated in vivo DTH response. Pre-stimulation with proinflammatory cytokines abrogated the difference observed between unstimulated MSC2 and MSC6 since licensing MSC6 by IFN- $\gamma$ and TNF- $\alpha$ prior to injection resulted in similar effective inhibition of hypersensitivity reaction to that of MSC2.

Summary of the presented results: bone marrow MSC population is heterogeneous regarding osteogenic differentiation, pro-angiogenic properties and more explicitly immunosuppressive activity. Anti-inflammatory cytokines, IFN- $\gamma$ and TNF- $\alpha$ polarize MSC functions since they shift MSC clones from differentiation to anti-inflammatory activity. Licensing MSC clones by the above cytokines abolishes osteogenic differentiation and pro-angiogenic activity meanwhile the immunosuppressive function is remarkably elevated. Based on these results it may be reasonable to consider that licensing of MSCs prior to therapy of immunological disorders and contrarily, reduction of inflammation using anti-inflammatory drugs systemically prior to usage of MSCs in regenerative medicine could enhance the effectiveness of MSC therapy. 


\section{Köszönetnyilvánítás}

Először is szeretném megköszönni témavezetőimnek, Prof. Dr. Monostori Évának és Dr. Czibula Ágnesnek, hogy megismertették velem, hogy hogyan kell tudományosan megközelíteni egy kérdést, véghez vinni a kísérleteket, kiértékelni, következtetést levonni az eredményekböl. Továbbá abban is rengeteget segítettek, hogyan kell az eredményeket tudományos fórumokon előadni és belőlük tudományos cikket írni. Ezeket a tapasztalatokat nem csak a kutatói pályán, de az élet más területein is alkalmazni tudom. Köszönöm Monosnak, hogy személyével kiváló példát állított arról, hogy milyen egy jó csoportvezető, aki törődik a kollégáival és kellő szigorral segíti őket pályájukon az előrehaladásban. Ági segítségnyújtásával, gyakorlatias tanácsaival és rugalmas hozzáállásával élvezetessé varázsolta számomra a molekuláris biológiai munkát.

A csoportban eltöltött 5 év alatt értékes és kedves emberekkel dolgozhattam együtt, akik türelmesek és segítőkészek voltak velem, és amiért hálával tartozom mindegyiküknek. Szeretném megköszönni Dr. Fajka-Boja Robertának az in vitro és in vivo immunológiai kísérletek beállítását, tapasztalatainak átadását, valamint az áramlási citometriai adatok kiértékelésében nyújtott segítséget. Gercsó Andrásné Andinak nagyon hálás vagyok az MSC-k gondos fenntartásáért, növesztéséért. Hornung Ákosnak köszönöm a statisztikai elemzésekkel kapcsolatos észrevételeket. Szeretnék köszönetet mondani Dr. Kriston-Pál Évának, hogy megtanította nekem a prevascularis struktúra tesztet, egér nyirokcsomók izolálását, különböző mikroszkópok használatát és hogy segített az állatkísérletek elvégzésében. Szeretném megköszönni Dr. Blaskó Andreának, Makra Ildikónak, Novák Juliannának és Dr. Szebeni Gábor Jánosnak a vidám hangulatot.

Dr. Uher Ferenc számos ponton segítette a munkámat. Tanár úr izolálta az MSCket, rendelkezésemre bocsátott in vitro differenciálódási és hisztokémiai protokollokat. A vezetésével müködő laborban történt az MSC-k egyes sejtfelszíni markereinek vizsgálata Kudlik Gyöngyi segítségével. Emellett rengeteg hasznos észrevétele, tanácsa volt a munkát illetően. Mindezekért hálás köszönettel tartozom neki és csoportjának.

Dr. Katona Róbertnek szeretném megköszönni a rendelkezésemre bocsátott állatokat és ellenanyagokat, Dr. Vizler Csabának a H5V sejtvonalat és a TNF- $\alpha$-át. Hálás vagyok Dr. Puskás Lászlónak és Dr. Zvara Ágnesnek a q-RT-PCR kísérletekben nyújtott segítségért. Köszönöm Fehér Nórának és Kotogány Editnek, hogy segítettek az áramlási citometriás kísérletek elvégzésében. 
Köszönöm Dr. Széll Mártának és Dr. Vizler Csabának, hogy elvállalták doktori dolgozatom bírálatát és hálás vagyok a gondos javításért és a hasznos észrevételekért.

Köszönöm az SZBK Genetikai Intézetének, hogy lehetőséget kaptam $\mathrm{PhD}$ munkám elvégzésére az Intézetben, és hogy részt vehetettem az Intézet által számos konferencián, előadáson és egy tanulmányúton Svédországban.

Végül szeretném megköszönni családomnak, páromnak és barátaimnak, hogy $\mathrm{PhD}$ hallgatói évek alatt végig mellettem álltak és szeretetükkel támogattak. 